\title{
A INOVAÇÃO TECNOLÓGICA NA PRODUÇÃO DE EDIFÍCIOS IMPULSIONADA PELA INDÚSTRIA DE MATERIAIS E COMPONENTES
}

\author{
Dissertação apresentada à Escola \\ Politécnica da Universidade de São Paulo \\ para obtenção do título de Mestre em \\ Engenharia \\ Área de Concentração: Engenharia de \\ Construção Civil \\ Orientadora: Prof ${ }^{\mathrm{a}}$. Dr ${ }^{\mathrm{a}}$. Mercia Maria \\ Semensato Bottura de Barros
}




\title{
A INOVAÇÃO TECNOLÓGICA NA PRODUÇÃO DE EDIFÍCIOS IMPULSIONADA PELA INDÚSTRIA DE MATERIAIS E COMPONENTES
}

\author{
Dissertação apresentada à Escola \\ Politécnica da Universidade de São Paulo \\ para obtenção do título de Mestre em \\ Engenharia
}




\section{FICHA CATALOGRÁFICA}

Martins, Marcelo Gustavo

A inovação tecnológica na produção de edifícios impulsionada pela indústria de materiais e componentes/ M. G. Martins. São Paulo, 2004.

Dissertação (Mestrado) - Escola Politécnica da Universidade de São Paulo. Departamento de Engenharia de Construção Civil.

1. Inovações tecnológicas (Desenvolvimento; Implantação) 2. Parcerias 3. Indústrias 4. Materiais e componentes de construção I. Universidade de São Paulo. Escola Politécnica. Departamento de Engenharia de Construção Civil. II.t. 


\section{AGRADECIMENTOS}

À professora Mercia Maria Semensato Bottura de Barros fica meu agradecimento especial, pela orientação segura e o apoio em todos os momentos.

Gostaria de registrar meu agradecimento também àqueles que de forma direta colaboraram para a realização deste trabalho:

Ao professor Fernando Henrique Sabbatini.

Ao Engenheiro Cláudio Vicente Mitidieri Filho.

Ao Arquiteto Carlos Alberto Tauil.

Ao Engenheiro Leonardo Tolaine Massetto.

Aos Tecnólogos Henrique Ferreira Pontes e Waldemir Carlos França.

Gostaria de registrar meu agradecimento também àqueles que de forma indireta colaboraram para a realização deste trabalho:

Aos professores Ubiraci Espinelli Lemes de Souza, Jonas Silvestre Medeiros, Sílvio Burrattino Melhado, Luiz Sérgio Franco e Francisco Ferreira Cardoso.

Aos colegas da pós-graduação com quem tive a oportunidade de realizar alguns trabalhos acadêmicos Luiz Augusto dos Santos, Érika Paiva Tenório de Holanda, Luciana Alves de Oliveira, Flávio Leal Maranhão, Max Junginger, Elizabeth Montefusco Lopes, Cláudia Nascimento de Jesus e Alexandre Taveira de Paula.

Finalmente gostaria de registrar meu agradecimento àqueles que fazem parte da minha vida e que sempre me incentivaram a prosseguir, enfrentando todos os obstáculos:

Aos meus pais Daisy e Jeronymo e à minha namorada Léa. 


\section{RESUMO}

Apesar dos fornecedores de materiais e componentes serem a principal fonte de inovação no setor da construção, eles geralmente apresentam uma postura passiva na implantação de novas tecnologias no processo produtivo das empresas construtoras. Nos últimos anos, porém, diversos pesquisadores têm apontado para uma nova tendência no sentido de as construtoras estreitarem relações com seus fornecedores, buscando ampliar a atuação destes. Indo além do simples fornecimento de componentes, essas empresas são chamadas a dividir ou assumir maior responsabilidade em todo o processo produtivo. Entretanto, essas relações não vêm se fazendo de maneira sistêmica, ocorrendo em função da experiência de cada um dos envolvidos. Este trabalho reúne e analisa os principais estudos disponíveis na literatura a respeito dos processos de desenvolvimento e de implantação de inovações, no setor de construção de edifícios, bem como estudos que tratam das relações entre construtoras e seus fornecedores, destacando-se aqueles que tratam de parcerias. Além disso, apresenta-se um caso prático, relativo a uma inovação destinada à produção de vedação vertical de edifícios multipavimentos, que vem sendo desenvolvida e comercializada por um grande fabricante de componentes de alvenaria do Estado de São Paulo. Essa inovação tem sido implementada por meio de parceria com empresas construtoras e fornecedoras de materiais, componentes e serviços. Os resultados do presente trabalho permitem depreender que, através da aplicação de um modelo de desenvolvimento adequado, o fornecedor da inovação ampliou seu mercado de atuação e, além disso, aumentou a rentabilidade de seus negócios. Com a reunião de dados da literatura e a partir da análise do caso prático sintetiza-se um modelo que pode auxiliar os fornecedores de materiais e componentes no desenvolvimento e implantação de uma inovação tecnológica, além do estabelecimento de relações mais adequadas com as empresas construtoras. 


\begin{abstract}
Although the suppliers of materials and components have been the main source of innovation in the construction industry, they generally present a passive attitude in the implementation of new technologies into the production process of construction companies. Recently, researchers identified a new trend under which construction companies are working closer to suppliers, mainly through partnerships, looking to them to increase their roles from the mere supply of components to the sharing of responsibility for the entire production process. Such relationship vary on a case by case basis, depending on the experience of each participant. In this connection, this work compiles and analyzes the major studies available in the literature related to the development and implementation processes of innovation as well as research about the relationship between construction companies and their suppliers, focusing on partnerships. Moreover, this work presents a case study involving innovation applied to walls of multiple-level buildings, which has been developed and commercialized by a large manufacturer of mansory components in the state of São Paulo, Brazil, through partnership with construction companies and suppliers of materials, components and services. The results indicate that, through application of an appropriate development model, the supplier of innovation enlarged his market and, in addition, increased the profitability of his business. Based on literature and a practical case study this work summarizes a development model that may help suppliers of materials and components to develop and implement technology innovation as well as to establish an appropriate relationship with the construction companies.
\end{abstract}




\section{SUMÁRIO}

Lista de Figuras, i

Lista de Tabelas, iii

Lista de Abreviaturas, iv

RESUMO

ABSTRACT

1 INTRODUÇÃO 1

1.1 Justificativa para o desenvolvimento da pesquisa ...................................... 1

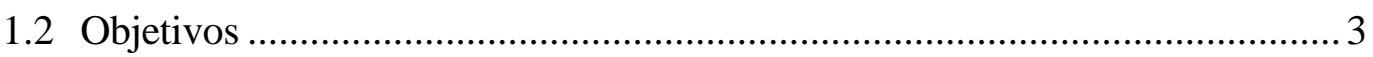

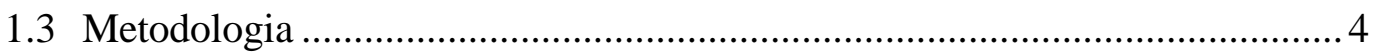

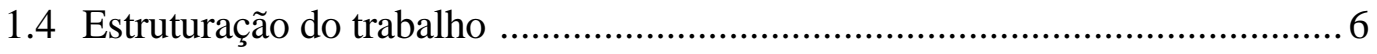

2 A INOVAÇÃO TECNOLÓGICA NO SUBSETOR EDIFICAÇÕES .............8

2.1 Identificação e caracterização da inovação nas edificações ............................ 8

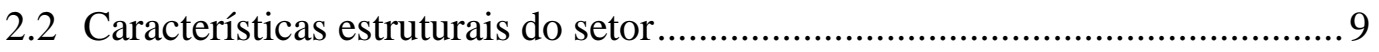

2.3 A inovação como estratégia competitiva nas empresas construtoras e na indústria de materiais e componentes ....................................................... 13

2.4 Elementos que se constituem em dificuldades à inovação .......................... 16

2.4.1 Dificuldades no âmbito das empresas construtoras ............................. 17

2.4.2 Dificuldades no âmbito da indústria de materiais e componentes ........ 18

3 DESENVOLVIMENTO E IMPLANTAÇÃO DE INOVAÇÕES TECNOLÓGICAS NA PRODUÇÃO DE EDIFÍCIOS .................................... 20

$3.1 \mathrm{O}$ processo de desenvolvimento de inovações .............................................. 20

3.2 O processo de implantação de inovações .....................................................26

3.3 Os novos papéis e atitudes dos fornecedores de materiais e componentes... 32

4 A FORMAÇÃO DE PARCERIAS ENTRE AS EMPRESAS CONSTRUTORAS E OS FORNECEDORES DE MATERIAIS E

COMPONENTES .35 
4.1 A formação de parcerias como estratégia para o desenvolvimento de inovações

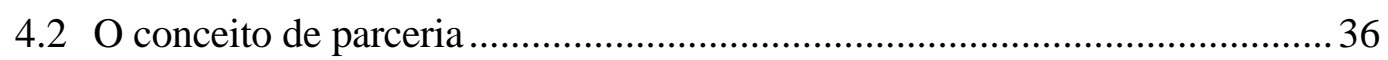

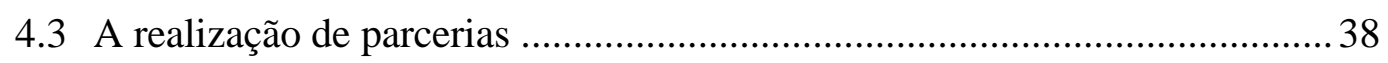

5 CASO PRÁTICO: A INOVAÇÃO IMPULSIONADA POR UM FORNECEDOR DE COMPONENTES DE ALVENARIA

5.1 O cenário da indústria produtora de blocos de concreto ............................. 43

$5.2 \mathrm{O}$ fornecedor frente aos novos desafios ..................................................... 45

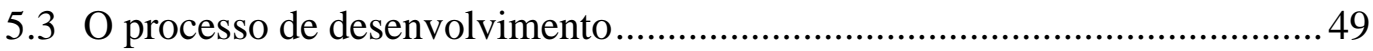

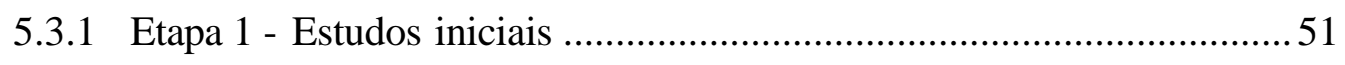

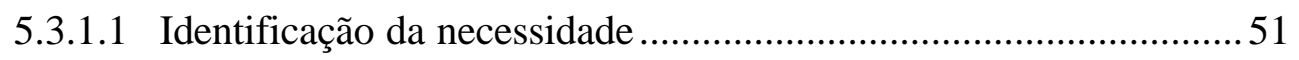

5.3.1.2 Problematização ................................................................... 52

5.3.1.3 Análise da viabilidade técnico-econômica-financeira ....................53

5.3.1.4 Formulação técnica do problema ..................................................56

5.3.1.5 Concepção de soluções alternativas para o problema ....................57

5.3.1.6 Análise de exeqüibilidade técnico-econômica-financeira das

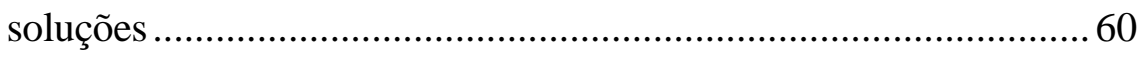

5.3.1.7 Formulação do conjunto de soluções exequiíveis ...........................61

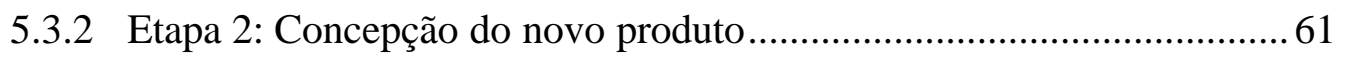

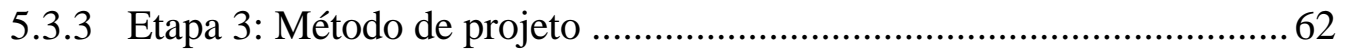

5.3.3.1 Definição de componentes e soluções básicas de projeto............... 63

5.3.3.2 Definição de soluções detalhadas de projeto ...................................64

5.3.3.3 Definição de especificações para parametrização da estrutura ...... 64

5.3.3.4 Criação e consolidação de linguagem projetual específica............ 66

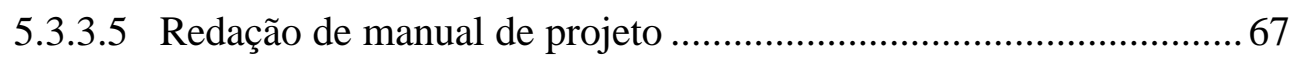

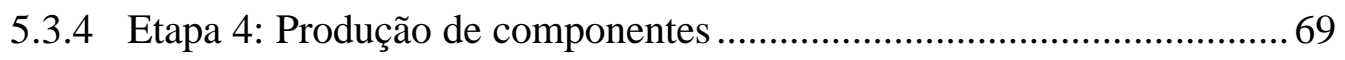

5.3.4.1 Projeto de componentes Glasser .................................................... 69

5.3.4.2 Projeto de outros componentes .................................................... 70

5.3.4.3 Formação de parcerias ................................................................ 72

5.3.4.4 Produção experimental dos componentes e elementos .................. 72

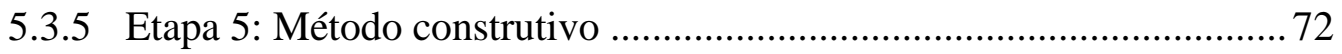

5.3.5.1 Definição das técnicas de execução ............................................. 72 
5.3.5.2 Criação e projeto de ferramentas e equipamentos .76

5.3.5.3 Experimentação das técnicas de execução.................................... 78

5.3.5.4 Consolidação do método executivo ............................................... 79

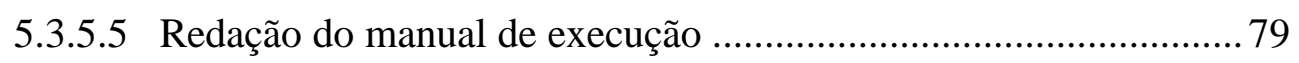

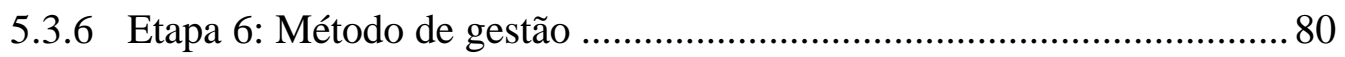

5.3.6.1 Criação de método de planejamento ................................................ 80

5.3.6.2 Criação de método de gerenciamento da produção ....................... 82

5.3.6.3 Criação de método de controle da produção ................................. 85

5.3.7 Etapa 7: Avaliação experimental....................................................... 88

5.3.8 Etapa 8: Construção de protótipos ....................................................... 90

5.3.8.1 Contratação e projeto de vedações em edifícios protótipos ........... 90

5.3.8.2 Construção das vedações em edifícios protótipos e implantação das técnicas executivas e de gestão.................................................. 91

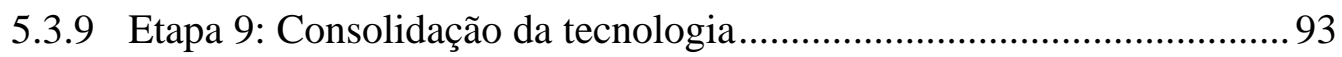

5.3.9.1 Avaliação das implantações protótipo ........................................... 93

5.3.9.2 Consolidação dos manuais de projeto, execução e gestão ............. 94

5.3.10 Etapa 10: Comercialização em escala de mercado ............................... 95

5.3.10.1 Definição da estratégia comercial .............................................. 97

5.3.10.2 Estruturação do sistema de comercialização................................. 98

5.3.10.3 Redação de contratos de comercialização...................................... 98

5.3.10.4 Identificação e treinamento de aplicadores credenciados..............99

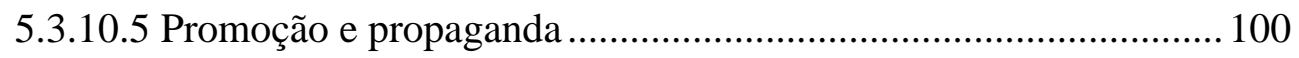

5.3.10.6 Comercialização em escala piloto ................................................ 100

5.3.10.7 Comercialização em escala de mercado...................................... 103

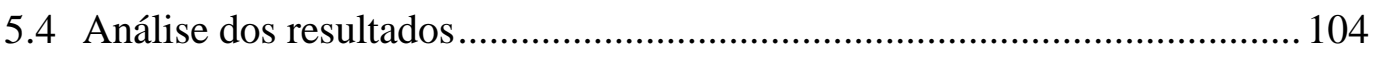

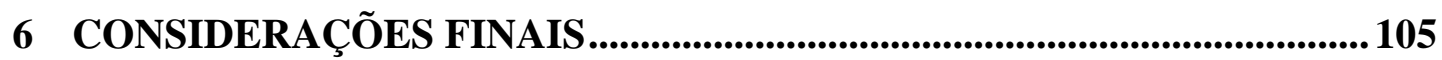

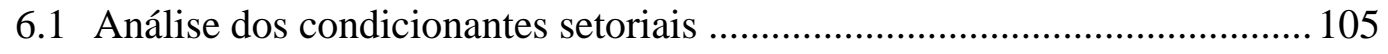

6.2 Proposta para condução do processo de desenvolvimento ......................... 106

6.3 Sugestões para o desenvolvimento de trabalhos futuros............................. 111

6.4 Considerações finais ............................................................................ 112

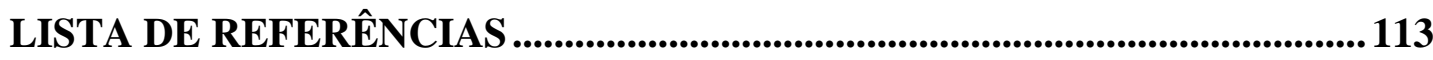


LISTA DE BIBLIOGRAFIA CONSULTADA .........................................................117

ANEXO A.............................................................................................................................. 120

ANEXO B.......................................................................................................................... 121

ANEXO C................................................................................................................................ 122

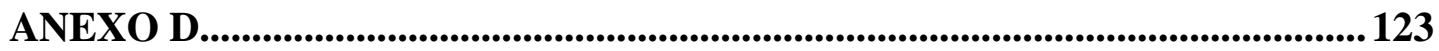

ANEXO E..................................................................................................................... 126

ANEXO F...................................................................................................................... 127

ANEXO G ............................................................................................................................ 128

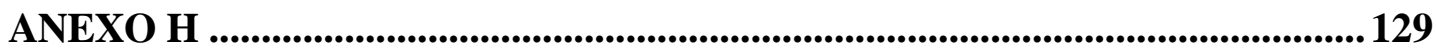

ANEXO I ............................................................................................................................ 130

ANEXO J .......................................................................................................... 131 


\section{LISTA DE FIGURAS}

Figura 3.2 - Ilustração das etapas, fases e ciclos iterativos da estratégia metodológica proposta por Sabbatini (1989).

Figura 3.3 - Ilustração da estrutura conceitual do modelo da indústria de sistemas complexos.

Figura 5.1 - Ilustração das etapas e ciclos iterativos do modelo de desenvolvimento do SVM. 50

Figura 5.2 - Utilização da fração um sexto (1/6) imediatamente após a amarração de canto de parede, a fim de recuperar a amarração a $10 \mathrm{~cm}$ nas duas paredes

Figura 5.3 - Foto que ilustra os componentes de alvenaria do SVM para a espessura nominal igual a $10 \mathrm{~cm}$.

Figura 5.4 - Fotos que ilustram as telas metálicas, ferramenta e acessórios para a

fixação das telas. .71

Figura 5.5 - Fotos que ilustram a verga e a contraverga empregada pelo SVM. ......71

Figura 5.6 - Foto que ilustra a aplicação do chapisco rolado. 73

Figura 5.7 - Foto que ilustra a execução da marcação da alvenaria. 74

Figura 5.8 - Foto que ilustra a fixação das telas metálicas à estrutura. 74

Figura 5.9 - Foto que ilustra a execução da elevação da alvenaria. 75

Figura 5.10 - Foto que ilustra a região de fixação da alvenaria à estrutura. .75

Figura 5.11 - Foto que ilustra o modelo protótipo do carrinho transportador de blocos.

Figura 5.12 - Foto que ilustra o gabarito de madeira sendo utilizado para o posicionamento das telas metálicas. .78

Figura 5.13 - Fotos que ilustram a bisnaga e a palheta sendo utilizadas para a aplicação de argamassa.

Figura 5.14 - Foto que ilustra o edifício protótipo PA. 91

Figura 5.15 - Foto que ilustra o edifício protótipo PB. 92 
Figura 5.16 - Foto que ilustra o edifício protótipo PC …….......................................93

Figura A - Fluxograma da Etapa 1 - Estudos Iniciais ... 120 


\section{LISTA DE TABELAS}

Tabela 4.1 - Benefícios e riscos envolvidos na parceria....................................... 40

Tabela 5.1 - Dimensões reais e massas das unidades de alvenaria ...........................63

Tabela C - Especificações das telas metálicas empregadas no SVM..................... 122

Tabela D.1 - Dimensões e massa das vergas utilizadas no SVM.......................... 123

Tabela D.2 - Dimensões e massa das vergas retas utilizadas no SVM. .................. 124

Tabela D.3 - Dimensões e massa das contra-vergas utilizadas no SVM................. 125 
LISTA DE ABREVIATURAS

$\begin{array}{ll}\text { ABCP } & \text { Associação Brasileira de Cimento Portland } \\ \text { ABNT } & \text { Associação Brasileira de Normas Técnicas } \\ \text { DATec } & \text { Documentos de Avaliação Técnica } \\ \text { IPT } & \text { Instituto de Pesquisas Tecnológicas de São Paulo } \\ \text { MPSConst. } & \text { Métodos, Processos e Sistemas Construtivos } \\ \text { NBR } & \text { Norma Brasileira } \\ \text { NR } & \text { Norma Regulamentadora } \\ \text { PA, PB e PC } & \text { Edifícios Protótipos A, B e C } \\ \text { Sinat } & \text { Sistema Nacional de Avaliações Técnicas } \\ \text { SVM } & \text { Sistema de Vedação Modular }\end{array}$




\section{INTRODUÇÃO}

O desenvolvimento do presente trabalho foi motivado pelas visitas realizadas pelo autor, no primeiro semestre de 2000, num dos canteiros de obras onde a inovação apresentada no caso prático estava começando a ser implementada. Nesse canteiro, um fornecedor de componentes de alvenaria comercializava, com a garantia de desempenho, um sistema de produção de alvenaria de vedação modular, integrando o fornecimento de todos os materiais e componentes, os serviços de aplicação e as atividades de controle. Ou seja, tratava-se da comercialização da parede pronta, onde o fornecedor participava de todas as etapas do processo produtivo, inclusive das atividades de projeto.

Quanto aos resultados que vinham sendo alcançados, tanto a empresa construtora quanto o fornecedor da inovação mostravam-se satisfeitos, apesar de identificarem uma série de pequenos entraves que precisariam ser equacionados. Desta forma, essa nova forma de comercialização que se pode chamar de "inovadora" apresentava-se como uma proposta com grande potencial que, se bem explorada, seria capaz de motivar outros fornecedores de materiais e componentes a trilhar o mesmo caminho.

O grande potencial identificado nesta proposta com vistas à ampliação do número de empresas fornecedoras a trilhar esse caminho e a necessidade de eliminar os entraves até então existentes é que motivou o autor a estudar mais profundamente o tema.

No entanto, este trabalho não está limitado a analisar essa inovação e os atores específicos envolvidos e sim analisar a inovação impulsionada pela indústria de materiais e componentes, a fim de aumentar sua capacidade competitiva e contribuir para a melhoria do processo de produção de edifícios.

Neste capítulo apresenta-se inicialmente a justificativa para o desenvolvimento da pesquisa e, a seguir, apresentam-se os objetivos, a metodologia e a estruturação do trabalho, com a síntese de cada capítulo.

\subsection{Justificativa para o desenvolvimento da pesquisa}

Um tema que vem despertando um interesse crescente nas empresas do setor da construção é a inovação tecnológica que, segundo Sabbatini (1989) pode ser 
entendida como sendo "um aperfeiçoamento tecnológico, resultado das atividades de pesquisa e desenvolvimento internas ou externas à empresa, aplicado ao processo de produção do edifício objetivando a melhoria de desempenho, qualidade ou custo do edifício ou de uma parte do mesmo".

Acredita-se que esse interesse é devido principalmente ao acirramento da concorrência entre as empresas do setor, sendo que a inovação pode representar uma vantagem competitiva e conduzir as empresas a uma posição de destaque frente a seus concorrentes, seja através da redução de custos de produção, aumento da qualidade dos produtos ou serviços ou mesmo através da indução de novos mercados através da oferta de produtos diferenciados. Este trabalho tem como foco as empresas construtoras e principalmente os fornecedores de materiais e componentes e duas constatações motivaram a opção por essa análise:

- os fornecedores de materiais e componentes representam uma das principais fontes de inovação, atuando no desenvolvimento de novos produtos ${ }^{1}$ e ofertandoos ao mercado cons umidor;

- as empresas construtoras têm buscado modernizar e racionalizar seus sistemas produtivos e, dentre as diversas ações empreendidas, tem-se destacado a aquisição e introdução dessas inovações nos canteiros de obras.

Tem-se assim dois atores que, atuando conjuntamente a fim de aumentar as suas capacidades competitivas, podem impulsionar a inovação no setor, colaborando para a melhoria do processo de produção de edifícios.

No entanto, os fornecedores de materiais e componentes em geral não assumem a responsabilidade pelo desempenho de seus produtos em uso, limitando-se a garantir o produto na embalagem ou, no máximo, orientando os usuários quanto aos procedimentos necessários à sua utilização. Além disso, não é usual que essas empresas colaborem, por exemplo, no desenvolvimento das atividades de projeto ou fornecendo os serviços de aplicação. Portanto, as inovações apresentam-se

\footnotetext{
${ }^{1}$ Neste trabalho um novo produto é considerado uma inovação na construção de edifícios quando, conforme Sabbatini (1989), "incorporar uma nova idéia e representar um sensível avanço na tecnologia existente em termos de: desempenho, qualidade ou custo do edifico, ou de uma sua parte".
} 
geralmente como soluções incompletas e os riscos envolvidos têm sido assumidos principalmente pelas empresas construtoras.

Por diversos motivos que serão abordados ao longo deste trabalho, as empresas construtoras encontram grande dificuldade na condução do processo de implantação de inovações e, nos últimos anos, essas empresas vêm buscando diminuir os riscos que têm assumido através da ampliação do papel de seus fornecedores, do simples fornecimento de componentes, para dividir ou assumir maior responsabilidade em todo o processo produtivo.

No entanto, o relacionamento entre as empresas construtoras e seus fornecedores é marcado pela falta de colaboração e confiança, sendo que os arranjos contratuais convencionais estabelecem condições que geralmente motivam as partes envolvidas a se verem como rivais.

Diversos estudos, principalmente na bibliografia internacional, têm apontado para uma nova tendência em que as empresas construtoras vêm estreitando suas relações com os seus fornecedores, principalmente através da formação de parcerias, alcançando benefícios tais como a diminuição dos custos de produção e o aumento da qualidade dos empreendimentos, a divisão de responsabilidades e dos riscos envolvidos, a colaboração no desenvolvimento das atividades de projeto e, até mesmo, a colaboração no desenvolvimento de novos produtos.

No Brasil, no entanto, a formação de parcerias entre as empresas construtoras e os seus fornecedores de materiais e componentes é ainda um assunto pouco conhecido do meio técnico e restrito a um número reduzido de casos práticos.

Nesse contexto é que se propõe a realização deste trabalho, analisando-se a inovação tecnológica na construção de edifícios impulsionada pela indústria de materiais e componentes, procurando contribuir para que as empresas construtoras e principalmente os fornecedores de materiais e componentes utilizem a inovação como uma vantagem competitiva e é com esta visão que se estabelecem os objetivos do presente trabalho, expressos a seguir.

\subsection{Objetivos}

Os principais objetivos do trabalho são: 
a) reunir e analisar os principais estudos disponíveis na bibliografia relacionados aos processos de desenvolvimento e de implantação de inovações e também aqueles que tratam das relações entre as empresas construtoras e seus fornecedores de materiais e componentes, destacando-se a formação de parcerias;

b) apresentar e analisar um caso prático relativo a uma inovação destinada à produção de vedação vertical de edifícios multipavimentos, que vem sendo desenvolvida e comercializada por uma grande empresa fabricante de componentes de alvenaria do Estado de São Paulo, por meio de parcerias com empresas construtoras e também com empresas que fornecem materiais, demais componentes e serviços;

c) sintetizar o modelo de desenvolvimento utilizado pelo fornecedor da inovação do caso prático apresentando-o como uma ferramenta que pode auxiliar os fornecedores de materiais e componentes em geral na condução dos processos de desenvolvimento e implantação de uma inovação e também auxiliar no estabelecimento de relações mais adequadas com as empresas construtoras.

\subsection{Metodologia}

Inicialmente foi realizada uma revisão bibliográfica, buscando-se identificar:

- as características estruturais do setor com impacto no processo de inovação tecnológica na produção de edifícios;

- os principais estudos relacionados à condução dos processos de desenvolvimento e de implantação de inovações na produção de edifícios;

- estudos referentes às relações entre as empresas construtoras e seus fornecedores em geral, destacando-se a formação de parcerias como um tipo de relacionamento que apresenta diversos benefícios potenciais para ambas.

Da análise desses estudos foram sintetizadas as principais ações que devem ser empreendidas principalmente pelos fornecedores de materiais e componentes e, além disso, são identificados os novos papéis que devem desempenhar.

Para o desenvolvimento do trabalho contou-se, também, com o estudo de um caso prático cujo foco de análise concentrourse nos processos de desenvolvimento e de 
implantação da inovação, considerando-se essencialmente a visão do fornecedor; mas, analisando-se também as dificuldades de relacionamento entre os diversos atores envolvidos, sendo os principais: o fornecedor da inovação; seis empresas fornecedoras de serviços, parceiras do fornecedor; quatro escritórios de projetos, qualificados pelo fornecedor; e oito empresas construtoras com empreendimentos desenvolvidos em parceria com o fornecedor.

Para se alcançar os objetivos pretendidos buscou-se identificar as razões que motivaram a decisão do fornecedor a investir no desenvolvimento de um novo produto a ser oferecido no mercado, bem como as etapas do processo de desenvolvimento da inovação. Esta etapa do trabalho foi realizada através de entrevistas com o Engenheiro Fernando Henrique Sabbatini, professor doutor do Departamento de Engenharia de Construção Civil da Escola Politécnica da Universidade de São Paulo, especialista no desenvolvimento de novas tecnologias construtivas e consultor do fornecedor no processo de desenvolvimento da inovação, e com o Arquiteto Carlos Alberto Tauil, diretor técnico-comercial da empresa Glasser Pisos e Pré-Moldados Ltda. e responsável pela condução do processo de desenvolvimento dentro da empresa fornecedora.

Além disso, para melhor compreender os processos de desenvolvimento e de implantação da inovação, a partir do ano de 2001 o autor passou a fazer parte da equipe de implantação, vivenciando o dia-a-dia do processo de desenvolvimento, a partir da sua implantação em escala piloto e diversos dados fundamentais para a descrição do processo de desenvolvimento dessa inovação foram coletados pelo autor através de reuniões periódicas realizadas junto com os atores envolvidos, em aproximadamente cinqüenta canteiros de obras visitados num período de três anos.

Os dados coletados em campo contemplaram as diretrizes para os projetos, especificação dos materiais e componentes, as técnicas e procedimentos para a execução dos serviços, a organização e treinamento das equipes de produção, o controle do processo de produção, a avaliação da produtividade e qualidade dos serviços, o relacionamento comercial entre as empresas, a forma de contratação do fornecedor, entre outros. Esses dados foram organizados e analisados à luz da conceituação teórica desenvolvida a partir da bibliografia disponível, validando os 
resultados de alguns estudos e propondo uma nova visão do assunto pela identificação das principais barreiras e dificuldades práticas enfrentadas.

Com todos os dados levantados e devidamente organizados, foi possível ao autor proceder a uma cuidadosa reflexão, fazendo análises, sobretudo qualitativas, que culminaram com a proposta, ainda que singela, de algumas diretrizes importantes que deverão orientar o trabalho futuro de outras empresas fornecedoras que se propuserem a trilhar este caminho.

\subsection{Estruturação do trabalho}

O trabalho está desenvolvido em cinco capítulos, além deste relativo à introdução.

No segundo capítulo é descrito e analisado o contexto da inovação tecnológica no subsetor edificações, sendo inicialmente identificado e caracterizado o tipo de inovação tratado neste trabalho. Nesse capítulo analisa-se a inovação como estratégia competitiva adotada pelas empresas construtoras e pelos fornecedores de materiais e componentes, identificando também os principais elementos que se constituem em dificuldades ao processo de inovação nessas empresas.

No terceiro capítulo reúnem-se e analisam-se os principais estudos disponíveis na bibliografia considerando-se os processos de desenvolvimento e implantação de inovações na produção de edifícios. Nas análises destacam-se principalmente os novos papéis a serem desempenhados pelos fornecedores de materiais e componentes para alcançar vantagens competitivas.

No quarto capítulo apresenta-se a formação de parcerias como uma relação entre as empresas construtoras e os seus fornecedores de materiais e componentes favorável à inovação no setor da construção e ao aumento da capacidade competitiva dos participantes. Nesse capítulo busca-se identificar os benefícios e as limitações desse tipo de relacionamento.

No quinto capítulo é apresentado e analisado um caso prático referente a uma inovação que vem sendo desenvolvida e comercializada por um grande fornecedor de componentes de alvenaria do Estado de São Paulo, por meio de parcerias com empresas construtoras e também com empresas que fornecem materiais, demais componentes e serviços. Neste capítulo analisam-se as relações entre essas empresas, 
bem como o modelo aplicado pelo fornecedor na condução dos processos de desenvolvimento e de implantação dessa inovação.

No sexto e último capítulo analisa-se o modelo de desenvolvimento aplicado pelo fornecedor da inovação do caso prático à luz da fundamentação teórica desenvolvida nos capítulos 2, 3 e 4 e, ainda, apresentam-se algumas diretrizes importantes que deverão orientar o trabalho futuro de outras empresas fornecedoras. A seguir, apresentam-se algumas sugestões para o desenvolvimento de trabalhos futuros quanto ao processo de inovação tecnológica na construção e, finalmente, as conclusões gerais do trabalho. 


\section{A INOVAÇÃO TECNOLÓGICA NO SUBSETOR EDIFI CAÇÕES}

Neste capítulo é descrito e analisado o contexto da inovação tecnológica no subsetor edificações, onde a inovação tem sido uma importante estratégia competitiva adotada pelas empresas construtoras e pelos fornecedores de materiais e componentes.

Inicialmente, é importante destacar que a inovação na produção de edifícios ocorre em níveis diferentes e o item a seguir identifica e caracteriza esses níveis, bem como estabelece o nível considerado neste trabalho.

\subsection{Identificação e caracterização da inovação nas edificações}

Amorim (1999) identifica e descreve três diferentes níveis no processo de inovação na produção de edifícios. São eles:

a) inovação de produto de construção: refere-se aos produtos acabados de construção que incorporam novas tecnologias, seja através de serviços ou novos equipamentos. São exemplos os 'residence-services', 'apart-hotéis' e 'edifícios inteligentes'. Esse nível de inovação é mais perceptível ao usuário;

b) inovação de produto para a construção: caracteriza-se pela introdução de novos produtos para a construção na forma de insumos e não altera o produto final de modo evidente para o usuário. No entanto, esse tipo de inovação requer alterações no processo de produção e, desta forma, representa uma inovação para as empresas construtoras e seus fornecedores;

c) inovação organizacional: caracteriza-se pela modernização da estrutura de produção através de novas formas de gerência e controles, inclusive de qualidade. Esse tipo de inovação está inter-relacionada com a anterior, no entanto, apresenta características próprias e pode prescindir da utilização de no vos insumos.

Segundo a classificação proposta por Amorim (1999), neste trabalho trata-se especificamente da inovação de produto para a construção, isto é, aborda-se a introdução de um novo produto que, necessariamente, implica em alteração no processo de produção da empresa construtora. Observa-se, ainda, que dependendo de como o novo produto é comercializado, ele pode requerer, também, alterações na organização para a produção do fornecedor da inovação, sendo que essa 
problemática será melhor discutida com a apresentação do caso prático no quinto capítulo.

\subsection{Características estruturais do setor}

Rezende; Abiko (2001), analisando o resultado de diversos estudos quanto à inovação e sua articulação com a economia e a sociedade, classificam esses estudos em cinco grandes grupos segundo a ênfase:

1. Grupo 01 - na tecnologia como chave para o seu próprio desenvolvimento: os estudos que pertencem a esse grupo centram-se nas questões técnicas e em geral negligenciam as articulações da tecnologia com a sociedade e a economia, acreditando ser possível um desenvolvimento técnico desarticulado destas;

2. Grupo 02 - na identificação e análise das especificidades do setor que justificam o seu atraso em relação a outros setores da economia: os estudos que pertencem a esse grupo apontam as particularidades do setor da construção e as interrelacionam com o desenvolvimento econômico. As análises que fazem ampliam muito a compreensão do processo de inovação, no entanto, dentro dessas análises, a tecnologia passa a ter um papel passivo de resposta em relação às questões sociais e econômicas;

3. Grupo 03 - na compreensão do impacto das mudanças tecnológica sobre o processo de trabalho: os estudos que pertencem a esse grupo abandonam a preocupação em explicar o atraso do setor da construção e buscam a compreensão do funcionamento do setor e as mudanças que ele vem sofrendo ao longo dos anos, analisando sobretudo o impacto das mudanças tecnológicas sobre o processo de trabalho. Nesses estudos, no entanto, a tecnologia continua tendo um papel passivo como agente capaz de provocar mudanças sobre si mesma;

4. Grupo 04 - na análise mais genérica do processo de inovação no setor da construção: os estudos que pertencem a esse grupo não se filiam a nenhuma das correntes anteriores e a grande contribuição refere-se à abrangência das análises que fazem, incluindo, por exemplo, os fornecedores de materiais e componentes como fonte de inovação no setor;

5. Grupo 05 - no desenvolvimento de metodologias específicas para a melhoria produtiva do setor: os estudos que pertencem a esse grupo estão mais próximos 
das teorias administrativas de introdução de inovações, diferentemente dos grupos anteriores que em geral aproximam-se das teorias econômicas ${ }^{2}$. Esses estudos em sua maioria analisam a implantação de inovações e os sistemas de qualidade nas empresas construtoras.

Com a perspectiva de analisar principalmente a contribuição dos fornecedores de materiais e componentes no processo de inovação no subsetor edificações, o presente trabalho aproxima-se do quarto grupo descrito por esses autores; no entanto, amplia o espectro de atuação desses fornecedores, principalmente considerando a sua participação nos processos de desenvolvimento e de implantação de inovações.

Para que esses fornecedores identifiquem as necessidades de mercado ou até mesmo induzam necessidades e desenvolvam inovações é necessário que compreendam inicialmente as características estruturais do setor, apontadas pelos estudos que pertencem ao segundo grupo identificado por Rezende; Abiko (2001).

Slaughter (1998), que estuda o processo de inovação nos Estados Unidos, descreve e analisa algumas características específicas do setor da construção daquele país com impacto no processo de inovação:

a) escala física: a escala física dos bens construídos estabelece certas limitações operacionais que afetam o desenvolvimento e uso de uma inovação. As atividades de construção são desenvolvidas principalmente no local final do bem construído e a pré-fabricação está limitada ao espaço disponível nos galpões industriais e ao tipo de transporte requerido. As inovações que necessitam de controle das condições do ambiente durante a implantação podem ter sua aplicação restrita. Além disso, quando uma inovação é testada, os resultados mais confiáveis são obtidos em protótipos em escala real;

b) complexidade: a complexidade dos bens construídos representa mais uma limitação operacional no desenvolvimento e uso de uma inovação. A maior parte dos bens construídos consiste de diversos e diferentes sistemas que interagem entre si e com o meio ambiente e essas interações não são facilmente

\footnotetext{
${ }^{2}$ Segundo Rezende; Abiko (2001), os trabalhos do quarto grupo aproximam-se mais das teorias econômicas na medida em que destacam a importância em se compreender a vinculação econômica entre as diversas empresas do setor para estimular a transformação do setor.
} 
caracterizadas e compreendidas. A introdução de uma inovação pode criar perturbações por todos os lados e um outro sistema pode ser negativamente afetado;

c) período de uso: a maior parte dos bens construídos é projetada considerando a vida útil de no mínimo cinqüenta anos e certas construções, principalmente de infraestrutura, têm funcionado há centenas de anos. Assim, uma inovação não deve ser avaliada em curto prazo e considerando apenas o contexto atual, mas sim, considerando um longo período, o potencial de falhas e a acessibilidade para eventuais reparos e modificações durante sua utilização;

d) contexto organizacional: em geral a inovação na construção existe dentro de uma aliança temporária entre organizações independentes e concentradas num único projeto e, tão logo o projeto seja concluído, a aliança é dissolvida. Diferentemente das organizações tradicionais de manufatura, que têm um grupo interno permanente responsável pelo desenvolvimento de pesquisas de projeto e implantação, na construção, geralmente a inovação ocorre de forma fragmentada e dividida nas etapas de projeto, fabricação e implantação entre os diversos participantes. Além disso, na construção os fornecedores são selecionados para cada projeto e muitas vezes não são utilizados novamente em projetos futuros;

e) contexto social e político: o projeto de um edifício deve ser elaborado freqüentemente segundo especificações detalhadas de acordo com códigos e regulamentos, enquanto os produtos manufaturados tradicionais, por outro lado, são freqüentemente avaliados pelo seu desempenho e não por descrições de projeto e fabricação, inclusive para produtos como automóveis, que também apresentam impactos na saúde e segurança.

As considerações de Slaughter (1998) sobre a escala física, a complexidade e o período de uso são cabíveis à realidade nacional. Entretanto, considerando-se o contexto organizacional, observa-se que diversas empresas construtoras, no Brasil, vêm buscando um relacionamento mais estável e duradouro com seus fornecedores e empresas subcontratadas. Porém, os compromissos estabelecidos entre essas empresas ainda não favorecem a colaboração e a confiança necessárias no processo de inovação e, dada a importância deste assunto no contexto do presente trabalho, o 
relacionamento adequado à inovação entre as empresas construtoras e seus fornecedores será abordado com mais detalhes no quarto capítulo.

Quanto ao contexto social e político, enquanto a norma brasileira de desempenho não entrar em vigor ${ }^{3}$, pode-se classificar a normalização do setor como sendo de caráter predominantemente descritivo e, em alguns casos, desatualizada. A possibilidade de avaliação de uma inovação também pelo seu desempenho em uso pode estimular mais empresas a investirem no desenvolvimento e utilização de inovações construtivas.

Há ainda uma grande dificuldade no estabelecimento de critérios necessários à homologação, avaliação ou aprovação de produtos ou processos construtivos inovadores. Como bem enfatiza o Engenheiro Luiz Guilherme de Matos Zigmantas, da Gerência de Filial de Apoio ao Desenvolvimento Urbano de São Paulo da Caixa Econômica Federal, os agentes financeiros, "sob o peso da responsabilidade de gestão de recursos públicos, acabam por atuar, na prática, como definidores sobre qual tecnologia poderá ser utilizada de forma mais ostensiva em conjuntos habitacionais, ainda que rejeitem o rótulo de 'homologadores' de sistemas ou produtos inovadores" (MITIDIERI FILHO et al., 2002).

A realidade é que a falta de uma entidade homologadora tem feito com que os agentes financeiros rejeitem a utilização de novas tecnologias como, por exemplo, as vedações verticais em gesso acartonado, que tiveram de passar por um longo período de estudos internos à Caixa Econômica Federal para que pudessem ter seu emprego parametrizado e somente, então, liberado.

Nesse contexto, o Instituto de Pesquisas Tecnológicas de São Paulo - IPT, vem atuando no sentido de superar essa dificuldade e atualmente coordena um projeto denominado Sistema Nacional de Avaliações Técnicas - Sinat - de abrangência nacional, a ser adotado pelos agentes promotores e financeiros da habitação, setor produtivo e instituições técnicas. O projeto prevê a concessão de Documentos de

\footnotetext{
${ }^{3}$ A comissão de estudos 02:136.01 está propondo o projeto de norma para avaliação do desempenho de edifícios habitacionais de até 5 pavimentos. O texto base está disponível para consulta e download no site do Comitê Brasileiro de Construção Civil: www.cobracon.org.br.
} 
Avaliação Técnica - DATec - por instituições independentes ou neutras (MITIDIERI FILHO et al., 2002).

Mas, não é somente a ausência de normalização técnica adequada que limita o desenvolvimento tecnológico no País. Vargas (1979) já apontava dois outros importantes fatores que explicam o limitado progresso técnico na construção de edificações no Brasil. Esse autor enfatiza que os ganhos do setor são obtidos sobretudo através das atividades de comercialização e não das atividades de construção e, além disso, cita a grande disponibilidade e desarticulação da mão-deobra utilizada na construção. Esses fatores têm se alterado muito lentamente nos mais de vinte anos que se passaram desde as colocações desse autor e, por isto mesmo acredita-se que ainda inibem principalmente o investimento em inovações construtivas e na industrialização dos canteiros ${ }^{4}$.

A seguir analisa-se a inovação como uma estratégia competitiva nas empresas construtoras e na indústria de materiais e componentes.

\subsection{A inovação como estratégia competitiva nas empresas construtoras e na indústria de materiais e componentes}

Além de reconhecer as características estruturais do setor, é importante identificar as principais tendências das empresas construtoras e fornecedores de materiais e componentes quanto ao desenvolvimento e utilização de inovações, dentre as quais se destacam:

- a empresa construtora busca no mercado uma tecnologia e a insere no seu sistema produtivo: talvez este seja o modo mais comum das empresas construtoras adquirirem uma nova tecnologia. Porém, sua implantação representa um grande desafio para a maioria dessas e os principais motivos serão apresentados neste capítulo. Além disso, os riscos envolvidos são totalmente assumidos pelas empresas construtoras e muitas vezes inibem o investimento em novas tecnologias;

\footnotetext{
${ }^{4}$ Uma discussão mais aprofundada sobre a relação da mão-de-obra com o processo de inovação tecnológica pode ser encontrada no trabalho de Holanda (2003), não sendo objeto específico do presente trabalho.
} 
- a empresa construtora cria a necessidade e desenvolve uma nova tecnologia internamente: um número reduzido de empresas construtoras dispõem dos recursos necessários para o desenvolvimento de uma inovação internamente e os riscos envolvidos também são totalmente assumidos por elas;

- a empresa construtora cria a necessidade e forma parceria com fornecedores para desenvolver a inovação: a formação de parceria com fornecedores é uma alternativa para que as empresas construtoras viabilizem o desenvolvimento de uma inovação e essa questão será tratada com detalhes no quarto e quinto capítulos. No entanto, os processos de desenvolvimento e implantação, por envolver a necessidade de integração da inovação com outros subsistemas do edifício $^{5}$, são geralmente conduzidos pelas empresas construtoras. A parcela maior dos riscos envolvidos é assumida pelas empresas construtoras;

- os fornecedores induzem a necessidade na empresa construtora e fornecem uma inovação: essa certamente é uma alternativa pouco explorada pelo setor para a inovação na construção, ainda que ofereça vantagens competitivas potenciais para os fornecedores de materiais e componentes. Certamente, para aproveitar a vantagem competitiva, os fornecedores passam a assumir a maior parcela dos $\operatorname{riscos}^{6}$ envolvidos e, portanto, devem estar preparados para desempenhar novos papéis.

Diversos autores citam a inovação na construção como uma estratégia competitiva mundial, cada vez mais presente nas empresas do setor. No Brasil, a abertura do mercado no início dos anos 90 contribuiu para a evolução tecnológica do setor da construção na medida em que permitiu às empresas construtoras o acesso a novos componentes e equipamentos. Diversas grandes empresas internacionais estabeleceram-se no Brasil nessa época, diretamente ou por meio de associações com empresas nacionais, trazendo consigo tecnologia, componentes e equipamentos (ROCHA, 1997).

\footnotetext{
${ }^{5} \mathrm{O}$ edifício definido como um sistema está subdividido em diversos subsistemas tais como a estrutura de concreto armado, as instalações prediais, o contrapiso, os revestimentos, as vedações verticais, etc. ${ }^{6}$ Os principais riscos referem-se aos prejuízos quanto ao investimento efetuado e também ao desgaste da imagem da empresa frente ao mercado e a seus clientes.
} 
Além disso, Amorim (1999) afirma que a queda de financiamentos de origem estatal a partir do final dos anos 80 implicou na redução de preços e margens de lucros, exigindo maior produtividade das empresas do setor. Segundo esse autor, essa necessidade motivou as empresas construtoras a iniciarem um processo de reorganização da produção e utilização de inovações tecnológicas.

Segundo Ceotto (2002), a estabilidade econômica do primeiro período do plano real e a elevação do custo da mão-de-obra devido ao ganho dos trabalhadores também incentivaram as empresas construtoras a pensar na tecnologia como ferramenta de competitividade.

No entanto, as inovações raramente são desenvolvidas internamente às empresas construtoras e, segundo Amorim (1999), a questão tecnológica no sentido estrito de desenvolvimento de novos produtos, foi assumida pelos fornecedores de equipamentos e materiais enquanto as empresas construtoras direcionaram seus investimentos na organização de novas formas de gerência e controles, inclusive de qualidade.

É certo que a inovação constitui uma importante estratégia competitiva para a indústria de materiais e componentes, principalmente devido ao acirramento da concorrência promovida pela abertura do mercado nacional e também devido à grande concorrência entre fabricantes de produtos pouco diferenciados entre si.

Diversos pesquisadores identificam a indústria de materiais e componentes como a principal fonte de inovação no setor da construção; no entanto, essas empresas têm geralmente atuação passiva na implantação dessas tecnologias no processo produtivo das empresas construtoras. Segundo Amorim (1999), no Brasil "há uma forte segmentação da cadeia de produção e, conseqüentemente, das obrigações dos fornecedores intermediários frente ao consumidor final, ainda muito concentradas sobre a ponta de venda".

Segundo Sabbatini (2000b), a maioria dos fornecedores de materiais e componentes limita-se em garantir seus produtos na embalagem. Amorim (1999) observa uma tendência onde os fornecedores, ao iniciar a distribuição de um produto inovador, preocupam-se em estabelecer uma rede de assistência técnica para orientar os novos usuários nos procedimentos necessários ao sucesso de sua utilização. Além disso, 
esse autor destaca alguns casos em que os fornecedores estabeleceram parcerias com empresas prestadoras de serviços de aplicação para os consumidores, porém, "limitando-se à interface de seus produtos com o restante da obra". Assim, os fornecedores em geral transferem a responsabilidade pelo desempenho em uso de seus produtos para as empresas construtoras.

Para que um novo produto represente uma inovação para as empresas construtoras é necessário que ele seja efetivamente implantado no sistema produtivo dessas empresas construtoras e esse processo de implantação tem sido conduzido pelas empresas construtoras; porém, por diversos motivos que serão analisados ao longo deste capítulo, para a maioria dessas empresas a condução do processo de implantação representa um grande desafio, muitas vezes difícil de ser vencido (BARROS, 1996).

Nesse contexto, as empresas construtoras estão interessadas em ampliar o papel de seus fornecedores, do simples fornecimento de componentes especificados, para dividir ou assumir maior responsabilidade em todo o processo produtivo.

Apesar de lentamente, a indústria de materiais e componentes vem se reorganizando para atender a essa necessidade, sendo que algumas empresas já identificaram a demanda atual das empresas construtoras por soluções construtivas e não mais por apenas materiais e componentes (SABBATINI, 2000b).

Nesse sentido, os fornecedores deverão conduzir o processo de desenvolvimento de novos produtos a partir de uma estratégia que considere fatores como, por exemplo, o desempenho da inovação inserida no edifício e, portanto, deverão compreender o processo de produção de edifícios. Deverão compreender também as dificuldades enfrentadas pelas empresas construtoras na condução do processo de implantação das novas tecnologias e estabelecer novas relações com essas empresas, baseadas nos princípios de colaboração e confiança, cujo aprofundamento será feito nos capítulos 3 e 4.

\subsection{Elementos que se constituem em dificuldades à inovação}

Diversos elementos constituem-se em dificuldades à inovação no âmbito das empresas construtoras e da indústria de materiais e componentes, sendo os principais 
discutidos a seguir. Cabe salientar que, apesar de existirem, deverão sempre ser combatidos quando da definição da organização e estratégia das empresas, sejam elas construtoras como fornecedoras.

\subsubsection{Dificuldades no âmbito das empresas construtoras}

Nas empresas construtoras os principais fatores que dificultam o processo de inovação são:

- as empresas construtoras, em sua maioria, são de propriedade de empresários individuais ou familiares e geralmente não valorizam a contratação de profissionais qualificados para exercer funções vitais (BARROS, 1996);

- a postura conservadora de grande parcela das empresas construtoras ou incorporadoras (NAM; TATUM, 1992 e 1997; ROSENFELD, 1994 e AMORIM, 1999);

- a falta de competência técnica e de visão sistêmica dos profissionais das empresas construtoras e incorporadoras em geral (SABBATINI, 1998b);

- a estrutura e organização para a produção das empresas construtoras, em geral não favorecem a implantação de inovações (BARROS, 1996);

- o menor preço como o principal critério adotado por diversas empresas construtoras para a contratação dos diversos fornecedores de componentes e elementos do edifício, deixando de lado os condicionantes de ordem técnica que também têm grande peso (SABBATINI, 2000a);

- as empresas construtoras encontram, ainda hoje, dificuldades em integrar os diferentes agentes que participam de um empreendimento de construção, em especial, os empreendedores, projetistas, fornecedores e subcontratados (BARROS, 1996; SABBATINI, 1998b);

- as relações geralmente estabelecidas pelas empresas construtoras com seus fornecedores de materiais e componentes não estimulam a colaboração no desenvolvimento de novos produtos.

Alguns pesquisadores têm estudado a influência do porte das empresas na sua capacidade de inovar. Segundo Nam; Tatum (1997), algumas pesquisas indicam que 
as grandes empresas têm maior capacidade para investimento no processo de inovação e têm maior capacidade para tolerar riscos; no entanto, mesmo nas grandes empresas, alguns fatores que inibem a inovação estão geralmente presentes, sendo os principais:

- o isolamento da gerência;

- intolerância aos indivíduos com idéias revolucionárias;

- busca por resultados em curto prazo;

- racionalismo exagerado;

- burocracia excessiva;

- incentivos inadequados.

Cabe salientar que, no Brasil, esses fatores não são privilégios das grandes empresas, pois são comumente encontrados na organização das empresas construtoras em geral, independente do seu porte.

\subsubsection{Dificuldades no âmbito da indústria de materiais e componentes}

$\mathrm{Na}$ indústria de materiais e componentes os principais fatores que dificultam o processo de inovação são:

- os oligopólios formados por grandes fabricantes de matérias-primas tal como o cimento interferindo nos negócios e na capacidade de investimento em pesquisa e desenvolvimento tecnológico das pequenas e médias empresas dependentes desses insumos;

- a necessidade de ampliação dos recursos públicos e privados destinados à pesquisa, incentivando à inovação principalmente nas pequenas e médias indústrias em parceria com centros de pesquisa e universidades;

- a falta de motivação pela atividade de criação frente à questão das patentes e direitos de exploração de inovações, praticamente inexistentes no setor da construção;

- a falta de visão sistêmica e de compreensão quanto ao processo de produção de edifícios dos fornecedores de materiais e componentes em geral; 
- a inviabilidade econômica de desenvolvimento de um novo produto por motivos tais como a baixa rentabilidade em função do menor preço como o principal critério adotado por diversas empresas construtoras para a escolha dos diversos componentes e elementos do edifício; a disponibilidade de mão-de-obra a baixo custo, característica ainda marcante no setor, e a carga tributária sobre produtos industrializados.

Pelas colocações anteriores, percebe-se que não é fácil empreender inovações tecnológicas na produção de edifícios; por outro lado, percebe-se também que não é possível para as empresas continuarem a produzir com baixos índices de produtividade e elevados índices de desperdícios, o que invoca uma postura ativa do setor. Por isto, no próximo capítulo apresentam-se os principais estudos relacionados aos processos de desenvolvimento e de implantação de inovações propostos para a indústria de produção de edifícios, com vistas a se enfrentar o desafio imposto ao setor de alcançar maior competitividade. 


\section{DESENVOLVIMENTO E IMPLANTAÇÃO DE INOVAÇÕES TECNOLÓGICAS NA PRODUÇÃO DE EDIFÍCIOS}

A seguir são apresentados os principais estudos disponíveis na bibliografia considerando-se os processos de desenvolvimento e de implantação de inovações na produção de edifícios, destacando principalmente os novos papéis a serem desempenhados pelos fornecedores de materiais e componentes para alcançar as vantagens competitivas pretendidas.

Inicialmente, apresenta-se um modelo de desenvolvimento de inovação que busca suprir a deficiência apontada no capítulo anterior quanto à necessidade de que a inovação proposta por um fornecedor deva estar inserida no processo de produção do edifício e de que deve considerar, no seu desenvolvimento, critérios tais como o desempenho e a facilidade construtiva.

Além disso, neste capítulo reúnem-se e analisam-se alguns estudos relacionados ao processo de implantação de inovação, buscando destacar as dificuldades enfrentadas pelas empresas construtoras e as relações estabelecidas entre elas e seus fornecedores.

\subsection{O processo de desenvolvimento de inovações}

Sabbatini (1989) elaborou uma metodologia específica para o desenvolvimento de métodos, processos e sistemas construtivos ${ }^{7}$ - MPSConst. - voltada para a criação de inovações tecnológicas. A metodologia apresenta dois níveis: doutrina e estratégia.

\footnotetext{
${ }^{7}$ Sabbatini (1989) definiu os conceitos de métodos, processos e sistemas construtivos:

- "Método construtivo é um conjunto de técnicas construtivas interdependentes e adequadamente organizadas, empregado na construção de uma parte (subsistema ou elemento) de uma edificação";

- "Processo construtivo é um organizado e bem definido modo de se construir um edifício. Um específico processo construtivo caracteriza -se pelo seu particular conjunto de métodos utilizado na construção da estrutura e das vedações do edifício (invólucro)”;
} 
A doutrina estabelece os princípios axiomáticos (filosofia) e as diretrizes paradigmáticas (diretrizes balizadoras) que norteiam o processo decisório. A filosofia estabelecida para a metodologia baseia-se nos princípios de máxima racionalização e de otimização de recursos e as diretrizes balizadoras são desempenho e construtibilidade ${ }^{8}$.

Neste trabalho sintetiza-se o modelo proposto por Sabbatini (1989) para o desenvolvimento de métodos, processos e sistemas construtivos - MPSConst., tendo em vista que está sendo aplicado, com algumas adaptações em função das características específicas da inovação, no desenvolvimento do novo produto apresentado como caso prático, no quinto capítulo. Portanto, embora existam outros modelos disponíveis na literatura, considera-se que o modelo escolhido seja o mais adequado, tanto pelo grau de detalhamento que oferece, quanto para facilitar a análise que se fará acerca do caso prático. As diversas etapas, fases e ciclos iterativos desse modelo são ilustradas na Figura 3.2 a seguir.

- "Sistema construtivo é um processo construtivo de elevados níveis de industrialização e de organização, constituído por um conjunto de elementos e componentes inter-relacionados e completamente integrados pelo processo".

${ }^{8}$ Conforme Sabbatini (1989) a “construtibilidade (de um método, processo ou sistema construtivo) é a propriedade que caracteriza um certo MPSConst. e que exprime a aptidão que este tem em ser executado". 


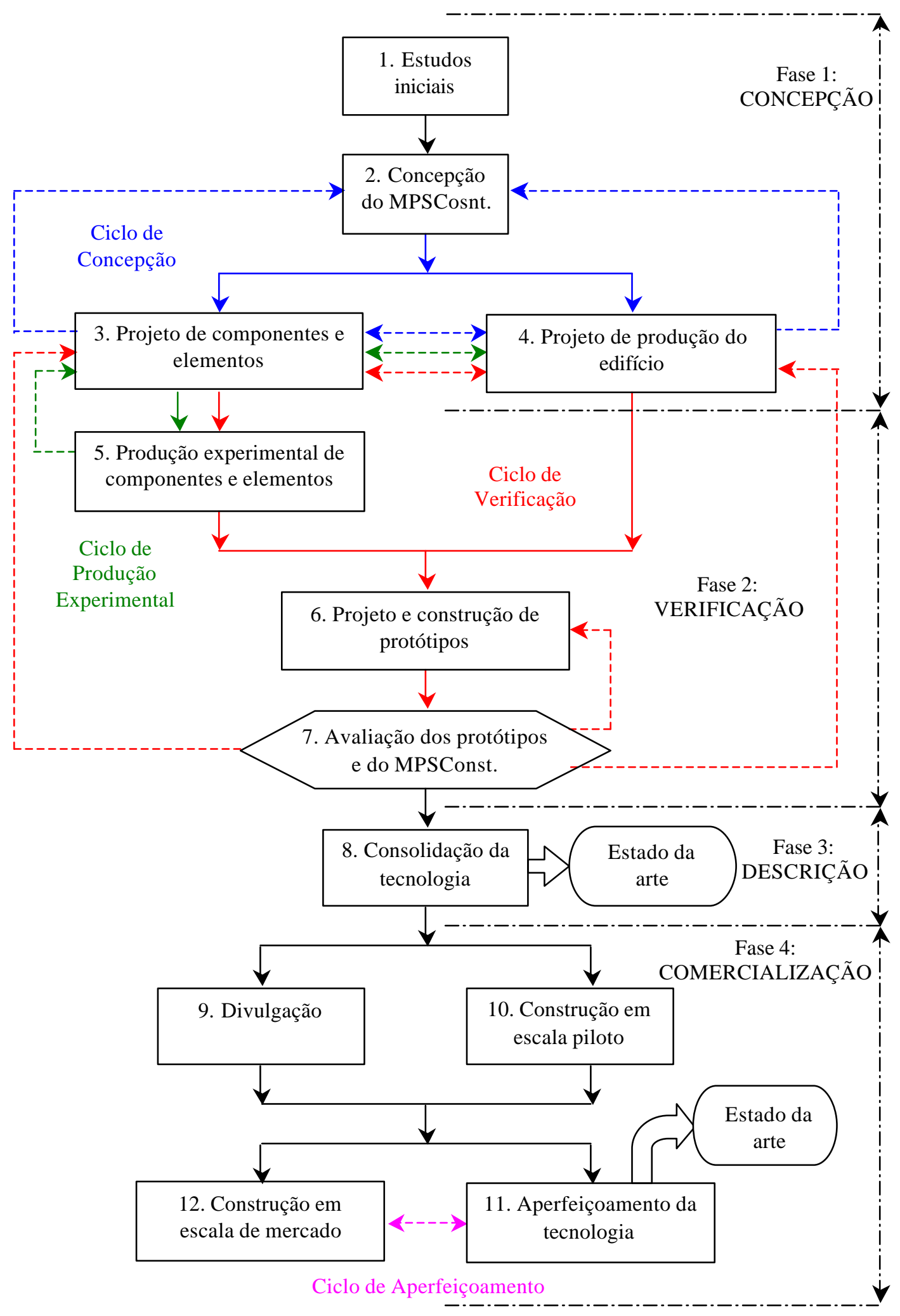

Figura 3.2 - Ilustração das etapas, fases e ciclos iterativos da estratégia metodológica proposta por Sabbatini (1989). 
A simbologia adotada no fluxograma da Figura 3.2 significa:

Etapa de execução de atividades, exceto avaliação;

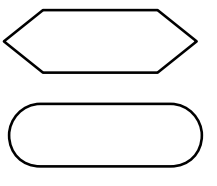

Etapa de avaliação;

Banco de informações;

Linha de fluxo da seqüência cronológica;

$-------\rightarrow$ Linha de fluxo das seqüências de retroalimentação;

<-----> Linha de fluxo da seqüência de interação (ação recíproca);

$\longrightarrow$ Linha de fluxo de informações;

As doze etapas serão aqui sintetizadas.

1. Estudos iniciais: nesta etapa as metas são "identificar a necessidade e a validade em se desenvolver um MPSConst.; formular tecnicamente o problema e formular um conjunto de soluções exeqüíveis". Considerando-se principalmente a estratégia da indução de uma necessidade, esta etapa adquire importância fundamental e, desta forma, é importante que todas as metas sejam efetivamente alcançadas sob pena de insucessos;

2. Concepção do MPSConst.: a partir do conjunto de soluções exeqüíveis, formulado na etapa anterior, a etapa de concepção tem como objetivos "fixar as características funcionais, formais e construtivas do MPSConst. e de suas partes". Esta etapa estabelece apenas uma concepção geral que será desenvolvida através de ciclos iterativos com as etapas 3 e 4, até a criação do projeto preliminar. As etapas 3 e 4 serão realimentadas em um segundo ciclo iterativo, pela etapa 5 e, em um terceiro ciclo, pela etapa 7 ;

3. projeto de componentes e elementos: o projeto dos componentes e elementos abrange a "definição das características funcionais, formais e materiais e os projetos para produção ${ }^{9}$ e avaliação experimental dos mesmos. (...) Da mesma

9 Barros (1996) definiu o entendimento de projeto para produção com sendo "um conjunto de elementos de projeto elaborado segundo características e recursos próprios da empresa construtora, para utilização no âmbito das atividades de produção em obra, contendo as definições dos itens 
maneira que na etapa antecedente, o primeiro estágio resulta em um projeto preliminar, o qual será refinado em três ciclos interativos distintos. (...) É essencial manter-se nesta etapa a visão do conjunto (sistêmica) para que ao otimizar o processo de uma parte, não se encontre uma solução desvantajosa para o sistema como um todo";

4. Projeto de produção do edifício (ou de suas partes): nesta etapa, são definidas as técnicas construtivas e também os métodos construtivos (no caso do objeto do desenvolvimento ser um processo ou um sistema) e projetados os detalhes de execução que irão permitir a construção do edifício ou um subsistema em acordo com o previsto na etapa de concepção. Portanto, nesta etapa é realizado o projeto de produção do edifício ou de um subsistema. Esta é última etapa da fase de concepção;

5. Produção experimental de componentes e elementos: a primeira etapa da fase de verificação tem como objetivo "produzir, em quantidade adequada, os componentes e elementos necessários para a construção do protótipo (ou protótipos)". O ciclo de produção experimental permite a avaliação e o aperfeiçoamento da produtibilidade e desempenho dos componentes e elementos;

6. Projeto e construção de protótipos : esta é uma etapa fundamental para avaliar a exeqüibilidade do projeto. O principal objetivo é avaliar o real desempenho da inovação, equacionando as incertezas das etapas anteriores;

7. Avaliação dos protótipos e do MPSConst.: esta etapa é caracterizada por dois estágios bastante distintos e adquirem grande importância porque são responsáveis pela realimentação das etapas anteriores (3 a 6). O primeiro estágio é definido pela avaliação durante o projeto e principalmente da construção do protótipo, identificando-se principalmente "as falhas na solução original de concepção dos MPSConst. e na construtibilidade do mesmo”. O segundo estágio é definido pela avaliação após a conclusão do protótipo, identificando-se as "deficiências no comportamento em uso, ou seja, no desempenho do edifício ou de suas partes”. Esta é a última etapa da fase de verificação e, antes de iniciar a

essenciais à realização de uma atividade ou serviço e, em particular: especificações dos detalhes e técnicas construtivas a serem empregados, disposição e seqüência de atividades de obra e frentes de serviço e uso e características de equipamentos". 
fase seguinte, segue-se a uma análise crítica que resulta em uma síntese final das fases de concepção e verificação - o reprojeto;

8. Consolidação da tecnologia: única da fase de descrição, esta é uma etapa complexa e de grande amplitude e pode ser dividida em dois estágios distintos. No primeiro estágio, de caráter descritivo, “deverão ser preparados documentos que contenham todas as informações pertinentes ao MPSConst. (...)", por exemplo, o projeto detalhado para a produção. O segundo estágio refere-se ao "projeto e planejamento para a fase de comercialização", considerando-se principalmente o projeto e planejamento para a produção de componentes e elementos, planejamento da divulgação e distribuição, projeto e planejamento do consumo e planejamento para revitalização da tecnologia e retirada do mercado;

9. Divulgação: é dividida em divulgação técnica e comercial. A divulgação técnica engloba "palestras, conferências, seminários, publicação de trabalhos técnicos, apresentação de trabalhos em simpósios e congressos, promoção de simpósios, edição de livros e manuais técnicos, demonstração em campo e laboratoriais, entrevistas técnicas, etc”. A divulgação comercial é fundamental para o sucesso de toda a pesquisa, devendo ser adequadamente planejada e as informações técnicas pertinentes deverão estar consolidadas em documentos completos;

10. Construção em escala piloto: a construção em escala piloto é uma etapa onde a comercialização é feita em escala reduzida, "para que a detecção das deficiências não cause problemas em níveis elevados e para que haja possibilidade de efetivar as correções em tempo hábil". Nesta etapa a tecnologia deverá estar sendo utilizada pelas indústrias de construção, permitindo assim sua adequação ao sistema produtor, e número limitado de repetições do seu emprego. Além disso, a construção em escala piloto deve ser considerada como "uma fonte importante de geração de informações para o aperfeiçoamento da tecnologia", que alimentarão a etapa 11 ;

11. Aperfeiçoamento da tecnologia: esta etapa tem como objetivos a manutenção do sistema e promover sua evolução conforme as forças de mercado. Na etapa de aperfeiçoamento ocorre a consolidação contínua da documentação da tecnologia, "alimentada por informações geradas na fase de comercialização piloto (etapas 9 
e 10) e realimentada ciclicamente pelas informações produzidas na fase de comercialização disseminada (etapa 12)";

12. Construção em escala de mercado: esta etapa assume grande importância em termos de "evolução das técnicas, de racionalização construtiva, de criação de detalhes otimizados, de minimização de custos por simplificação, de soluções criativas para problemas não antecipados, etc".

As subetapas de cada uma das etapas anteriormente sumarizadas, descritas e ilustradas através de fluxogramas por Sabbatini (1989), não serão abordadas neste trabalho, por constituírem-se em detalhamento não necessário para que os objetivos deste trabalho sejam alcançados.

Esse modelo, como será reforçado no quinto capítulo, apresenta-se como uma ferramenta bastante útil para orientar as decisões dos fornecedores de materiais e componentes quanto ao desenvolvimento de novas tecnologias.

No entanto, o sucesso do processo de inovação depende da sua efetiva implantação no sistema produtivo das empresas construtoras, isto é, aquelas que fazem uso do MPSConst. desenvolvido. Como já salientado, a implantação de uma nova tecnologia no processo produtivo de uma empresa, não é fácil de ser realizado; por isto, no item seguinte aborda-se essa questão específica, apresentando-se os principais estudos disponíveis na literatura.

\subsection{O processo de implantação de inovações}

A maioria dos estudos disponíveis na literatura sobre a implantação de inovações considera as empresas construtoras como responsáveis pela condução desse processo. Também a maioria desses estudos aponta as diversas dificuldades das empresas construtoras em conduzir de forma eficiente a implantação de uma inovação.

Winch (1998) propõe um modelo que busca classificar os diferentes atores envolvidos no processo de inovação em categorias ou níveis. A identificação dos papéis específicos desses atores é a principal contribuição desse modelo, considerando-se principalmente o papel das empresas construtoras na utilização e implantação de inovações disponíveis no mercado. 
Esse autor adaptou ao setor da construção uma teoria denominada de produtos e sistemas complexos (complex product systems), desenvolvida originalmente para a indústria de simulação aérea.

Essa teoria vem ganhando força no meio técnico por ser direcionada a um setor que apresenta diversas características semelhantes àquelas encontradas no setor da construção, sendo as principais:

- muitos elementos interconectados, feitos sob encomenda, organizados de modo hierarquizado;

- propriedades não lineares e continuamente surgindo, onde pequenas mudanças num único elemento do sistema pode conduzir a grandes mudanças por todo o sistema;

- alto grau de envolvimento do "cliente" $" 10$ no processo de inovação.

Winch (1998) adaptou essa teoria para a indústria da construção, então denominada de Indústria de Sistemas Complexos (Complex Systems Industry), e propôs um modelo cuja estrutura está ilustrada na Figura 3.3.

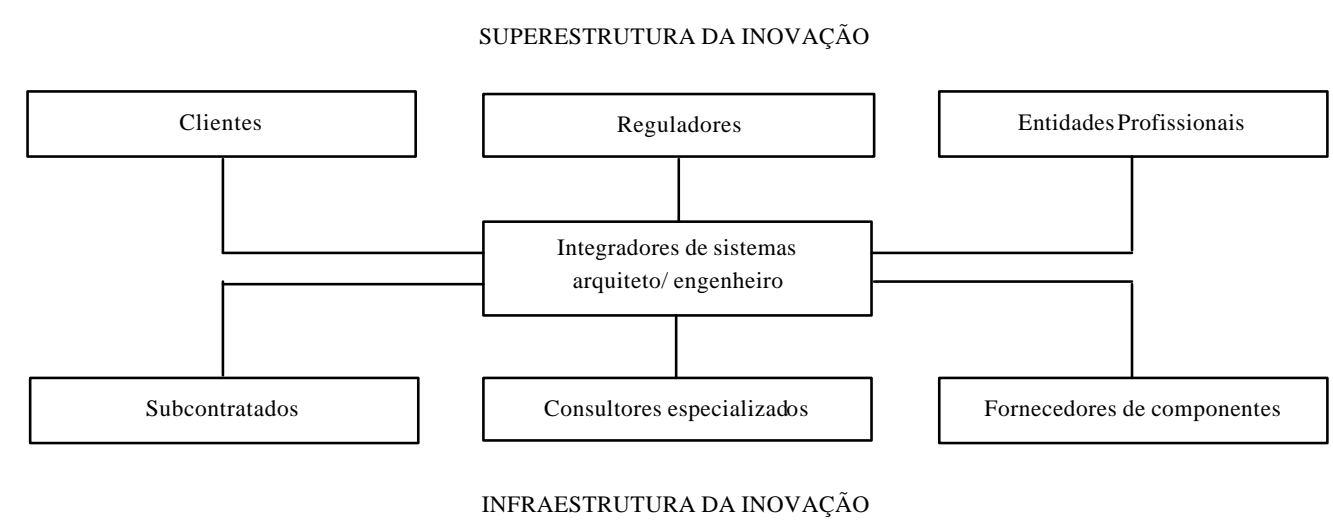

Figura 3.3 - Ilustração da estrutura conceitual do modelo da indústria de sistemas complexos (WINCH, 1998).

Considerando-se os papéis das empresas construtoras e fornecedores de materiais e componentes, esse autor destaca que as empresas construtoras assumem o papel de integradoras de sistemas, dividindo-o com os arquitetos e/ou engenheiros

\footnotetext{
${ }^{10}$ Como clientes entende-se que são aqueles que definem as características do produto final. Na construção, os incorporadores geralmente são os principais clientes.
} 
responsáveis pelas atividades de projeto. Esses atores, quando não cumprem adequadamente essa função, podem comprometer a qualidade e o desempenho do produto edifício.

No contexto nacional, as empresas construtoras geralmente assumem isoladamente a função de integradoras de sistemas, inclusive desenvolvendo ou coordenando as atividades de projeto. Assumem, portanto, toda a responsabilidade pela integração de uma inovação no processo de produção do edifício. No entanto, essas empresas encontram diversas dificuldades em assumir essa função, considerando-se principalmente as dificuldades na condução do processo de implantação de uma inovação.

Barros (1996), que propõe uma metodologia dirigida às empresas construtoras para a implantação de novas tecnologias construtivas disponíveis no mercado, destaca inicialmente que o sucesso potencial da implantação depende não somente da metodologia mas sobretudo do envolvimento da empresa e disposição para empreender as alterações necessárias para a criação de um ambiente favorável à implantação. Essa autora aponta a importância de um líder na condução do processo de implantação dentro da empresa.

O papel fundamental desempenhado pelo líder dentro da empresa construtora, com a finalidade de conduzir o processo de inovação, é destacado por diversos pesquisadores. Nam; Tatum (1997), baseados em entrevistas com mais de noventa profissionais do setor da construção envolvidos em dez empreendimentos inovadores bastante diferenciados nos Estados Unidos, apresentam e analisam detalhadamente o papel de indivíduos-chave no processo de inovação bem sucedido nesses empreendimentos. O estudo de caso de Nam; Tatum (1997) mostrou que os melhores resultados nos empreendimentos inovadores foram obtidos quanto mais elevado o nível de envolvimento e compromisso dos gerentes. A partir dos resultados de seu trabalho, os autores identificam dois fatores como sendo críticos para tornar os profissionais aptos a conduzir com sucesso o processo de inovação na construção:

- reserva de recursos: a disponibilidade de recursos é essencial para a inovação; porém, na medida certa. Exageros ou economias extremas podem inviabilizar os projetos. A medida certa de recursos tem sido o grande desafio das empresas e na 
opinião desses autores, o setor da construção é conservador e marcado pela resistência das empresas quanto à disponibilização de recursos necessários para a inovação;

- posição de destaque e competência técnica: um líder deve ocupar uma posição dentro da empresa que lhe confira autoridade e a força necessária para superar a resistência mencionada anteriormente. Além disso, deve possuir competência técnica, essencial para superar as incertezas da construção e diminuir os riscos envolvidos.

Esses autores acreditam que a competência técnica é imprescindível para que as incertezas da construção sejam superadas. No estudo realizado, observaram a organização e a estrutura mantidas por alguns gerentes, as quais conferiram a eles a competência técnica necessária, destacando:

- manter grupos administrativos internos em número adequado;

- apresentar capacidade interna para pesquisa, desenvolvimento e elaboração de projetos;

- dispor de meios para suprir a capacidade técnica, por exemplo, contratando consultoria especializada;

- possuir rico histórico quanto à inovação;

- atuar com alto grau de profissionalismo;

- manter parcerias duradouras com projetistas e outros fornecedores;

- e, em alguns casos, a empresa financiando a pesquisa e desenvolvimento para os fornecedores.

Essa estrutura é certamente favorável ao processo de inovação; no entanto, a grande maioria das empresas do setor nacional não dispõe de recursos, principalmente financeiros, necessários para organizar e manter tal estrutura. A falta de recursos financeiros dificulta o processo de inovação; porém, não o inviabiliza totalmente, considerando-se que nem todas as inovações exigem, por exemplo, altos investimentos. 
Atualmente os serviços de consultoria especializada têm sido muito utilizados pelas empresas, assim como a formação de parcerias entre empresas construtoras e seus fornecedores também tem sido uma tendência no setor.

Além de destacar a presença do líder como ponto de partida para o início do processo de implantação de inovações, Barros (1996) também apresenta cinco diretrizes balizadoras que devem orientar esse processo:

1. desenvolvimento da atividade de projeto: o projeto é o instrumento para a informação e fixação das novas tecnologias no sistema produtivo da empresa, desde que "incorpore as definições para a completa realização da produção, inclusive as relativas ao planejamento do empreendimento";

2. desenvolvimento da documentação: deve proporcionar meios para o repasse uniforme das tecnologias a todos os empreendimentos. A documentação deverá servir, por exemplo, como subsídio para o treinamento de todo o pessoal envolvido com a implantação;

3. desenvolvimento dos recursos humanos: deve permitir a capacitação tecnológica e organizacional da empresa, "através da motivação e do treinamento que envolva todos os níveis hierárquicos". Além disso, deve permitir menor variabilidade do sistema produtivo e a possibilidade de sua evolução contínua;

4. desenvolvimento do setor de suprimentos voltado à produção: deve facilitar e viabilizar a implantação das tecnologias construtivas racionalizadas, através "do envolvimento e de um melhor relacionamento entre as equipes de projeto, produção e suprimentos, para que sejam adquiridos materiais, componentes e equipamentos que atendam a produção";

5. desenvolvimento do controle do processo de produção: deve possibilitar o acompanhamento de todo o processo de produção, visando a sua qualidade e a do produto final. Além disso, deve permitir a realimentação do processo de implantação e a evolução das ações que visam melhoria.

Considerando o contexto do setor nacional, a implantação de novas tecnologias construtivas representa um grande desafio para a maioria das empresas construtoras, por diversos motivos, dentre os quais, pode-se dizer que as diretrizes balizadoras da metodologia proposta por Barros (1996) inexistem ou estão presentes somente parcialmente nas empresas construtoras. 
Quanto ao desenvolvimento das atividades de projeto apenas um número reduzido de empresas mantém um departamento específico para essa atividade e ainda persiste em diversas empresas a visão de que o projeto, por não atender adequadamente à produção, é uma ferramenta acessória e que envolve custos desnecessários. No entanto, nos últimos anos, têm existido alguns bons exemplos de como o desenvolvimento dos projetos para a produção tem colaborado para mudar a visão de algumas empresas frente ao projeto. Ou seja, os projetos voltados à produção têm implicado em redução de desperdício e aumento de produtividade e qualidade. A sua elaboração tem ficado ao encargo das empresas construtoras que, quando não dispõem de recursos humanos próprios, acabam por contratar os projetos de empresas especializadas.

Quanto ao desenvolvimento da documentação, a dificuldade principal das empresas construtoras é reunir os dados e analisar os resultados obtidos durante o processo de implantação, a fim de consolidar a documentação relativa à inovação. A documentação básica deve contemplar, por exemplo, as diretrizes para a elaboração dos projetos e os procedimentos de execução. A falta de documentação do processo inviabiliza, por exemplo, a adequação do treinamento das equipes envolvidas no processo de implantação da inovação bem como a detecção e correção de eventuais desvios.

O desenvolvimento dos recursos humanos talvez seja o maior desafio para as empresas. As relações humanas dependem de diversos fatores e também da combinação entre eles, que pode variar de indivíduo a indivíduo. Não é objetivo deste trabalho discutir ou apresentar modelos voltados à motivação dos recursos humanos; no entanto, cabem aqui algumas considerações. Além da crítica quanto à formação familiar da maioria das empresas construtoras, conforme item 2.4.1, essas empresas, salvo poucas exceções, não investem na qualificação e atualização dos conhecimentos de seus funcionários e tão pouco nos de seus fornecedores de mãode-obra (subempreiteiros) e é sabido que o reflexo do desconhecimento é a aversão a toda e qualquer novidade. A necessidade de qualificação atinge todos os níveis hierárquicos e quanto mais alto o nível, maiores são os efeitos negativos nas empresas. 
Esta diretriz balizadora proposta por Barros (1996) constitui-se, ainda, num grande desafio que a indústria da construção como um todo deverá enfrentar nos próximos anos se quiser, verdadeiramente, alcançar a competência tecnológica e organizacional.

O setor de suprimentos, em geral, não se comunica adequadamente com as equipes de projeto e produção. A maioria dos profissionais dessa área utiliza-se, principalmente pela falta de informações e conhecimento técnico e até mesmo por imposição hierárquica, do critério do menor preço para selecionar seus fornecedores. Agir no sentido de melhorar essas relações tem sido também um grande desafio para as empresas do setor.

O controle do processo de produção é uma das diretrizes mais complexas pois envolve o acompanhamento de todas as etapas de aplicação da nova tecnologia, desde o seu desenvolvimento até a utilização do empreendimento. O processo de produção deve ser acompanhado pelo nível hierárquico mais alto de ambas as empresas e o maior desafio é que as informações precisas cheguem sem distorções até esse nível.

No contexto deste trabalho, o fornecedor de materiais e componentes, compreendendo o processo produtivo de edifícios e as principais dificuldades que as empresas construtoras enfrentam na implantação de uma inovação, deverá assumir novos papéis, participando de todo o processo de implantação nas empresas construtoras.

\subsection{Os novos papéis e atitudes dos fornecedores de materiais e componentes}

Os fornecedores de materiais e componentes devem reconhecer seus novos papéis e a necessidade de novas atitudes a fim de alcançarem a vantagem competitiva que o desenvolvimento e comercialização de uma inovação pode trazer.

McCutcheon; Grant; Hartley (1997) destacam que a colaboração no desenvolvimento de novos produtos e tecnologias entre cliente/fornecedor é uma atividade nova para muitas empresas e requer mudanças nos papéis dos fornecedores. Esses autores destacam que a tarefa de entregar não só componentes, mas também serviços - em forma de colaboração na etapa de projeto e na resolução de problemas de ordem 
técnica - é o principal novo papel a ser assumido pelos fornecedores. Destacam também que a capacidade técnica do fornecedor em transmitir efetivamente suas habilidades tem um impacto significativo sobre a percepção dos seus clientes que buscam sua colaboração.

Por isto, acredita-se que as diretrizes propostas por Barros (1996) para orientar a implantação de uma inovação devam ser completamente compreendidas não só pelas empresas construtoras como também pelos fornecedores. As dificuldades enfrentadas pelas empresas construtoras na condução do processo de implantação geralmente são devidas às deficiências no cumprimento das diretrizes propostas. Nesse sentido, os fornecedores devem colaborar com as empresas construtoras para que essas dificuldades sejam superadas. Assim, devem considerar a participação nas atividades de projeto, planejamento, execução e controle da execução, inclusive avaliando a disponibilização de equipes de aplicadores e controle da execução como parte da estratégia de comercialização de um novo produto.

A prestação de serviços de aplicação não é usual para a maioria dos fornecedores; no entanto, estes devem se preparar para assumir essa nova responsabilidade e, na medida que passam a comercializar também serviços, podem aumentar a rentabilidade dos seus negócios, conforme será apresentado no quinto capítulo.

Portanto, os fornecedores devem se preparar para fornecer as garantias pelo desempenho do produto aplicado. A garantia, no entanto, envolve riscos que devem ser avaliados previamente pelos fornecedores de uma inovação e, para avaliarem esses riscos, é fundamental que apresentem visão sistêmica e compreendam o processo de produção de edifícios.

Finalmente, considerando-se a indução de uma necessidade como uma importante estratégia competitiva capaz de estimular a indústria e de reacender o seu crescimento, mesmo em momentos de instabilidade econômica, os fornecedores de materiais e componentes, através de uma postura pró-ativa, devem investir no desenvolvimento de novos produtos e tecnologias a fim de induzir novos mercados (MAHMOUD-JOUINI, 2000; NAM; TATUM, 1992).

No entanto, somente a disposição dos fornecedores de materiais e componentes não é suficiente para que os objetivos do processo de inovação sejam alcançados. É 
necessário que suas relações com as empresas construtoras apresentem condições adequadas e favoráveis ao sucesso dos processos de desenvolvimento e de implantação, o que é tratado no próximo capítulo. 


\section{A FORMAÇÃO DE PARCERIAS ENTRE AS EMPRESAS CONSTRUTORAS E OS FORNECEDORES DE MATERIAIS E COMPONENTES}

Neste capítulo inicialmente apresenta-se a formação de parcerias como estratégia para o desenvolvimento de inovações. A seguir, define-se o entendimento de parceria no contexto deste trabalho e, finalmente, apresentam-se os princípios para a realização de parcerias.

\subsection{A formação de parcerias como estratégia para o desenvolvimento de inovações}

Em geral as relações entre as empresas construtoras e os fornecedores de materiais e componentes são marcadas por interesses particulares de cada um, sendo que a forma de contratação convencionalmente praticada no setor não motiva as partes a colaborarem entre si. No entanto, ainda que lentamente, esse quadro vem se alterando e diversos estudos, dentre eles os de Koraltan; Dikbas (2002), Corswant; Tunälv (2002), Kwan; Ofori (2001), Kale; Arditi (2001), Daity; Briscoe; Millett (2001), Bresnen; Marshal (2000a) e (2000b), Fabrício; Melhado; Silva (1999), McCutcheon; Grant; Hartley (1997) e Isatto (1996), apontam as vantagens potenciais desse tipo de relacionamento entre empresas.

Koraltan; Dikbas (2002) analisam a aplicabilidade da formação de parcerias no setor da construção da Turquia, como resposta à crescente competição criada por questões tais como a globalização, o desenvolvimento acelerado da tecnologia da informação e comunicações e os avanços na tecnologia construtiva.

Fabrício; Melhado; Silva (1999), estudando as parcerias e estratégias de produção na construção de edifícios na cidade de São Paulo, afirmam que as parcerias entre os atores do processo de construção pode ser decisivo no sucesso dos empreendimentos e no aumento da capacidade competitiva dessas empresas.

Kwan; Ofori (2001), estudando soluções para resolver problemas e conflitos no setor da construção em Singapura, destacam a necessidade de integração das atividades 
dos diversos atores envolvidos no setor através da colaboração e estreitamento das relações entre eles.

Corswant; Tunälv (2002), estudando especificamente a colaboração dos fornecedores através da formação de parcerias no desenvolvimento de novos produtos na indústria automobilística da Suécia, apresentam os benefícios potenciais quanto à colaboração entre as empresas, tais como o acesso a habilidades complementares entre os agentes envolvidos, o acesso a novas tecnologias e mercados, a divisão dos riscos envolvidos, a redução do tempo demandado para o desenvolvimento de novos produtos e tecnologias, além da diminuição de custos e melhoria da qualidade. A criação ou abertura de novos mercados é também uma necessidade dos fornecedores de materiais e componentes no setor da construção, para se manterem no mercado e para se tornarem mais competitivos.

Para Bresnen; Marshall (2000a), a parceria pode ter um impacto positivo significativo quanto ao desempenho do projeto, não só com respeito a tempo, custo e qualidade, mas também com respeito a resultados mais gerais tais como alavancar a inovação e aumentar a satisfação do usuário.

Portanto, a formação de parcerias entre empresas tem sido uma tendência mundial visando ao aumento da capacidade competitiva dos participantes, à melhoria do processo de produção e à contribuição dos fornecedores de materiais e componentes no processo de desenvolvimento de novos produtos e tecnologias.

\subsection{O conceito de parceria}

No setor nacional de construção de edifícios as relações de parceria entre as empresas construtoras e seus fornecedores de materiais e componentes são pouco praticadas. Apenas recentemente o termo parceria começou a ser utilizado no setor da construção, mas ainda não há consenso acerca do seu real significado.

Daity; Briscoe; Millett (2001) afirmam que existem diversas definições de parceria; no entanto, referem-se normalmente a um arranjo estratégico onde duas ou mais empresas estão envolvidas em um ou mais projetos com o objetivo de diminuir custos e otimizar a eficiência. 
Para Koraltan; Dikbas (2002), uma das idéias mais proeminentes que está por trás do conceito de parceria é que todas as partes devem estar de acordo desde o início, através de uma estrutura formal, para enfocar a cooperação criativa e o trabalho em equipe, a fim de evitar divergências.

Para Bresnen; Marshall (2000a), em geral a parceria envolve um compromisso de cooperação entre as empresas para alcançar objetivos comuns. Isatto (1996) reforça essa idéia quando afirma que a obtenção de benefícios mútuos é o princípio básico da formação de parcerias, "os quais não poderiam ser obtidos de forma isolada pelos participantes através de um processo de sinergia".

Kwan; Ofori (2001) afirmam que empresas parceiras num mesmo contrato têm os mesmos objetivos que podem ser alcançados através da cooperação e da comunicação transparente para o benefício de todos. Além disso, ressaltam a importância da parceria ser estabelecida sob uma estratégia formal de compromisso, comunicação e trabalho de equipe a fim de prevenir disputas e incentivar a cooperação entre os envolvidos.

Segundo McCutcheon; Grant; Hartley (1997), as indústrias de montagem em geral estão interessadas em ampliar as atribuições e as responsabilidades de seus fornecedores. Para esses autores, a aproximação efetiva entre os responsáveis pelo desenvolvimento de produtos e seus fornecedores tem sido um elemento crescentemente importante no processo de inovação de produtos. Afirmam ainda que, dada à complexidade crescente de produtos em muitos campos, as empresas em geral devem utilizar as capacidades dos seus fornecedores mais efetivamente durante o desenvolvimento de produtos.

Embora o setor analisado por esses autores não seja o da construção, algumas características mostram-se semelhantes como, por exemplo, a busca das empresas construtoras por fornecedores que assumam ou dividam as responsabilidades pelo desempenho dos subsistemas em que seus materiais e componentes tenham sido empregados, responsabilizando-se também pela aplicação e fornecendo garantia de desempenho. 
Corswant; Tunälv (2002) destacam que o compromisso e a confiança necessários na formação de parcerias devem ser assumidos nos níveis hierárquicos mais altos das empresas participantes.

A partir das considerações anteriores e para definir um significado único ao longo do texto, este trabalho refere-se à parceria como sendo um compromisso formal, baseado nos princípios de colaboração e confiança, estabelecido no mais alto nível hierárquico entre duas ou mais empresas visando alcançar objetivos comuns.

Baseado neste conceito, analisam-se a seguir os principais condicionantes relacionados à realização de parcerias.

\subsection{A realização de parcerias}

Alguns pesquisadores criticam a natureza de algumas pesquisas que apontam somente os benefícios da formação de parcerias. Para Bresnen; Marshall (2000a), existem poucos trabalhos que usam o estudo de caso comparativo ou trabalho de pesquisa para investigar sistematicamente as condições sob as quais a parceria é mais apropriada, possível e efetiva na prática. Também citam que existem poucos trabalhos que buscam analisar sistematicamente a parceria sob perspectivas diferentes dentro da cadeia de produção da construção.

Para Kale; Arditi (2002), as transações entre as empresas construtoras e seus fornecedores parceiros envolvem uma quantidade significativa de incertezas. Algumas dessas incertezas originam-se da natureza do processo de construção e outro do desempenho potencial de um parceiro durante o processo de construção, sendo as principais: (a) as operações de construção são desenvolvidas em locais onde estão presentes incertezas relativas a condições climáticas e a condições do solo; (b) cada empreendimento requer um novo projeto, gerando novos problemas de produção relativos à coordenação e à integração da produção de grupos de trabalho especializados que desenvolvem tarefas interdependentes e (c) o próprio sistema de contratação é uma receita para a incerteza, uma vez que a estimativa de custo não é uma ciência exata. Além dessas incertezas, as empresas construtoras e subcontratadas também enfrentam dificuldades avaliando o desempenho um ao 
outro, com antecedência. $\mathrm{O}$ desempenho insatisfatório por qualquer uma das partes pode ter profundos efeitos negativos no outro.

Fabrício; Melhado; Silva (1999) citam os principais condicionantes do setor nacional da construção que potencializam e limitam a formação de parcerias:

- a quantidade e variedade de atores envolvidos, todos com significativas interferências e responsabilidades;

- a predominância de diversas pequenas e médias construtoras, dispersas pelo território e com um forte vínculo regional;

- a heterogeneidade acentuada entre os fornecedores, considerando-se o porte, tipos de produtos e serviços e quantidade de concorrentes.

$\mathrm{Na}$ análise desses autores, a heterogeneidade do setor e a fragmentação em empreendimentos únicos dificulta não só o estabelecimento de parcerias, mas também as previsões e os contratos de longo prazo. Além disso, analisam a dificuldade no estabelecimento de parcerias entre as empresas construtoras e os fornecedores de materiais de grande porte, uma vez que esses fornecedores encontram dificuldade no atendimento individualizado. Os autores citam a constância de processos e procedimentos construtivos na organização das empresas construtoras como um importante fator para estimular as parcerias. Finalmente, os autores destacam a existência de barreiras culturais e organizacionais "que tendem a nortear a relação por critérios de preço".

Isatto (1996), estudando as relações entre as empresas construtoras de edificações e seus fornecedores de materiais, cita os benefícios e os riscos envolvidos na parceria entre empresas, conforme o Tabela 4.1 a seguir. 
Tabela 4.1 - Benefícios e riscos envolvidos na parceria (adaptado de Isatto, 1996).

\begin{tabular}{|c|c|c|}
\hline & benefícios & riscos \\
\hline 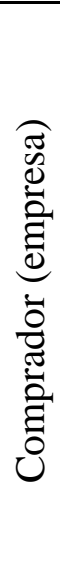 & $\begin{array}{l}\text { - } \text { redução de custos de produção; } \\
\text { - } \quad \text { aumento da qualidade; } \\
\text { e redução da complexidade de montagem } \\
\text { - } \quad \text { garantia de suprimento; } \\
\text { - } \quad \text { relações cooperativas com os } \\
\text { - } \text { fornecedores; } \\
\text { - } \text { transparisibilidade dos contratos; } \\
\text { custo dos fornecedores. }\end{array}$ & $\begin{array}{l}\text { - } \text { maior dependência do fornecedor; } \\
\text { - } \text { menvolve um novo estilo de negociação; } \\
\text { fornecedores; } \\
\text { - demanda um maior uso de ferramentas } \\
\text { gerenciais para administrar e } \\
\text { desenvolver os fornecedores; } \\
\text { maior apoio ao fornecedor; } \\
\text { perda do contato direto com } \\
\text { fornecedores secundários. }\end{array}$ \\
\hline 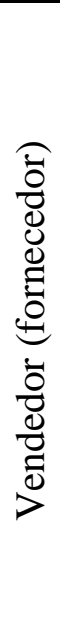 & $\begin{array}{l}\text { - } \text { previsibilidade dos contratos; } \\
\text { mão-de-obra e produção mais estáveis; } \\
\text { - } \text { aumento da eficácia dos esforços de } \\
\text { - } \text { influesquisa e desenvolvia nos processos de decisão do } \\
\text { comprador; } \\
\text { - } \text { a empresa torna-se o portão de entrada } \\
\text { obrigatório para as novas tecnologias } \\
\text { dos competidores; } \\
\text { - informação relativa à competição. }\end{array}$ & $\begin{array}{l}\text { - } \quad \text { transparência de informações de custos; } \\
\text { - } \quad \text { pressão para assumir as cargas de todas } \\
\text { as fases desde o projeto até a garantia, } \\
\text { enquanto aumenta a qualidade e diminui } \\
\text { os custos; } \\
\text { - } \quad \text { menor autonomia; } \\
\text { - } \quad \text { aumento dos custos de comunicação e } \\
\text { - } \quad \text { reordenação; } \\
\text { - } \quad \text { insegurança quanto à possibilidade da } \\
\text { extinção da parceria. }\end{array}$ \\
\hline
\end{tabular}

McCutcheon; Grant; Hartley (1997) citam que as amplas responsabilidades dos fornecedores dentro do programa de desenvolvimento de produto podem oferecer novas oportunidades, mas elas também exigem novas atribuições para os departamentos técnicos e comercial, que devem estabelecer uma ligação efe tiva com a organização do cliente. Esses autores, estudando a percepção de diversas empresas de setores de montagem frente à colaboração de seus fornecedores, destacam os principais resultados:

- a competência técnica é um fator essencial na seleção dos fornecedores potenciais como parceiros em longo prazo. Discussões com engenheiros ligados à área de desenvolvimento de produto revelaram que a competência do fornecedor foi julgada principalmente por sua reputação técnica e pelo conhecimento técnico ou habilidade demonstrada pela equipe de engenharia; 
- a disposição do fornecedor em trabalhar no projeto de desenvolvimento de produto pode influenciar favoravelmente os clientes a considerar a participação do fornecedor em projetos futuros.

Porém, para que os benefícios potenciais da formação de parceria sejam alcançados é necessário inicialmente a criação de um ambiente favorável. O compromisso formal de colaboração e confiança representa um desafio para a maioria das empresas.

Diante desse contexto, uma alternativa para a criação do ambiente favorável é a adoção progressiva do conceito de parceria. Segundo Koraltan; Dikbas (2002), algumas empresas têm obtido sucesso na adoção de parceria progressiva, inicialmente através de colaborações informais que evoluem para relações de parceria com estrutura formal.

Outra alternativa para a preparação do ambiente é a criação de incentivos contratuais para motivar os participantes. No entanto, o uso de incentivos também tem aplicação limitada e, conforme as conclusões do estudo de Bresnen; Marshall (2000b), existe a necessidade de pesquisas com o objetivo de explorar o impacto de incentivos sobre a qualidade de um empreendimento nas situações de parcerias. Os resultados da pesquisa conduzida por esses autores mostram que as conseqüências negativas potenciais devem ser cuidadosamente analisadas para que os incentivos sejam aplicados de modo adequado.

Dwyer; Schurr; Oh (1987) ${ }^{11}$ apud Isatto (1996), estabelecem que as parcerias devem ser implantadas através de um processo que envolve diferentes estágios englobando cinco fases gerais:

- conhecimento mútuo: inicia-se quando uma empresa identifica a possibilidade de realizar uma parceria com outra, sendo que "somente ocorrem reações unilaterais, nas quais os possíveis parceiros posicionam-se e adquirem uma postura propícia ao início da relação de parceria";

\footnotetext{
${ }^{11}$ Dwyer, F. R.; Schurr, P. H.; Oh, S. Developing buyer-seller relationships. Journal of Marketing, v.51, p.11-27 Abr, 1987.
} 
- exploração: inicia-se quando ocorrem as primeiras interações bilaterais, "onde os participantes consideram suas obrigações, benefícios, encargos e a possibilidade de trocas";

- expansão: ocorre quando os participantes consideram-se satisfeitos com o desempenho da outra parte. Nesta etapa, "a relação de parceria passa proporcionar maiores benefícios e interdependência para os participantes". No entanto, "a confiança e a satisfação mútua levam a um aumento nos riscos envolvidos na relação, principalmente porque os ganhos obtidos então dificultam a substituição do parceiro por outra empresa";

- comprometimento: "refere-se a garantias implícitas ou explícitas da continuidade da parceria". Nesta fase, a satisfação com a parceria impede a participação de outros possíveis parceiros que poderiam proporcionar os mesmos benefícios;

- dissolução: ocorre "quando os benefícios da parceria são superados pela insatisfação de um ou ambos os parceiros, inicia-se um processo de dissolução".

Cabe salientar que os participantes devem, conjuntamente, combater as limitações e as insatisfações identificadas nas suas relações.

No próximo capítulo apresenta-se um caso prático onde um fornecedor de componentes para alvenaria, através do desenvolvimento integrado com fornecedores parceiros, desenvolveu uma inovação e a comercializa para empresas construtoras, também através de relações de parcerias. 


\section{CASO PRÁTICO: A INOVAÇÃO IMPULSIONADA POR UM FORNECEDOR DE COMPONENTES DE ALVENARIA}

Neste capítulo apresenta-se um caso prático relativo a um novo produto destinado à produção das vedações verticais de edifícios multipavimentos com estrutura reticulada de concreto armado, denominado "Sistema de Vedação Modular" ou simplesmente SVM. O novo produto foi desenvolvido e vem sendo comercializado por um grande fabricante de componentes de alvenaria do Estado de São Paulo, a empresa Glasser Pisos e Pré-Moldados Ltda.

Inicialmente, investigam-se e registram-se os fatores que influenciaram a Glasser pelo desenvolvimento do SVM, que apresenta três características inovadoras. A primeira delas refere-se à nova forma de comercialização proposta pelo fornecedor, ou seja, a venda da parede e não do componente; a segunda refere-se à nova família de componentes modulares de alvenaria desenvolvida pelo fornecedor; e a terceira refere-se à estratégia adotada pelo fornecedor para viabilizar o desenvolvimento e implantação do novo produto, através da integração e colaboração de empresas parceiras. Essas três características inovadoras serão apresentadas com mais detalhes no desenvolvimento deste capítulo.

Além disso, neste capítulo são identificadas e descritas as principais etapas e subetapas do modelo de desenvolvimento do SVM utilizado pelo fornecedor.

\subsection{O cenário da indústria produtora de blocos de concreto}

Com a criação de centenas de pequenas indústrias informais e algumas empresas formais de porte médio produtoras de blocos de concreto, verifica-se que existe uma tendência atual de comercialização destes componentes como uma espécie de commodity, ou seja, uma tendência do bloco de concreto ser disponibilizado ao mercado com características similares e dentro de uma mesma faixa de preços. Atualmente, dezenas de empresas fabricantes de blocos de concreto possuem o Selo de Qualidade concedido pela Associação Brasileira de Cimento Portland - ABCP, o 
que reforça a percepção de mercado de que tais componentes, em geral, possuem desempenhos equivalentes entre $\mathrm{si}^{12}$.

Não obstante as características dos blocos serem distintas, há grande concorrência entre as empresas fabricantes, sendo que o preço do componente em si tem grande peso no momento de se definir por este ou aquele fabricante, enquanto a qualidade tem importância secundária.

Além disso, os blocos de concreto para vedação estão inseridos num mercado dominado pela alvenaria produzida com componentes cerâmicos e seu uso ainda sofre certa restrição, principalmente por parte de incorporadores devido a insucessos do passado $^{13}$.

Para acirrar ainda mais o mercado de comercialização destes componentes de alvenaria tem-se que, nos últimos anos, as divisórias internas de gesso acartonado vêm lentamente conquistando espaço no mercado, como mais uma opção para as vedações verticais internas de edifícios. E, apesar de pouco expressivos, há que se considerar também a ação dos fabricantes de painéis pré-fabricados de concreto que buscam mercado para o seu produto.

Por outro lado, as empresas construtoras e incorporadoras, aproveitando-se dessa situação de grande concorrência, impõem seus preços e condições de pagamento nas negociações com seus fornecedores. Desta forma, os baixos preços praticados pelo mercado consumidor dos blocos para alvenaria e sendo a qualidade um fator decisório secundário para grande parte desse mercado, os preços e qualidade dos

\footnotetext{
12 Vale destacar que esta percepção é equivocada uma vez que a qualidade dos blocos de concreto varia amplamente, sobretudo devido aos fatores ligados à sua produção. Por exemplo, o potencial de retração na secagem dos blocos de concreto, que representa uma propriedade fundamental e que é altamente dependente de cura adequada na etapa de produção, não é avaliado nos ensaios necessários para a obtenção do selo da ABCP; por outro lado, aceitam-se os mais variados tipos de cura como adequados à produção.

${ }^{13}$ Os insucessos no passado estão relacionados com o uso de blocos de concreto de baixa qualidade que implicaram no desempenho inadequado das paredes devido principalmente aos efeitos de movimentações higroscópicas dos componentes de alvenaria, por retração excessiva na secagem, que ocorre com maior grau nos blocos de concreto quando comparados aos blocos cerâmicos (SABBATINI, 1988).
} 
blocos de concreto têm sido nivelados por baixo, ou seja, os blocos de baixa qualidade disputam o mesmo mercado daqueles de qualidade superior.

Ao ambiente altamente concorrencial somam-se as incertezas na obtenção da principal matéria prima para a fabricação dos blocos de concreto: o cimento. As indústrias de cimento vêm arbitrando os preços e as condições de pagamento, interferindo nos negócios das empresas que utilizam o cimento como matéria prima e, em alguns casos, inviabilizando a permanência dessas empresas no mercado. Essa condição afeta demasiadamente as empresas fabricantes de bloco de concreto, que dependem do cimento em volume significativo para a fabricação de seus produtos.

Nessas condições, a rentabilidade dos negócios das empresas fornecedoras de blocos de concreto é baixa e dependente da comercialização de grandes volumes. O futuro da maioria dessas empresas é incerto e o desafio tem sido ampliar o mercado e aumentar a rentabilidade dos seus negócios.

Diante do cenário apresentado, a Glasser, para permanecer no mercado e manter sua posição de liderança no fornecimento de blocos de concreto, iniciou uma nova fase em seus negócios, descrita a seguir.

\subsection{O fornecedor frente aos novos desafios}

A partir da constatação de um mercado cada vez mais competitivo, a Glasser passou a investir na especialização dos recursos humanos e as ações empreendidas pela empresa voltaram-se para a comercialização de soluções construtivas em vez da simples venda de componentes, fornecendo aos seus clientes principalmente assessoria técnica.

Além disso, passou a induzir o mercado da construção para o uso racionalizado dos seus produtos, de forma a suprir seus clientes com novos modelos de componentes, visando a uma modulação adequada das alvenarias, evitando desperdícios e adaptações nas obras. Para tanto, as principais ações da empresa a fim de destacar as vantagens de seus produtos foram:

- cursos e palestras técnicas em institutos e associações de engenheiros e arquitetos; 
- cursos, na própria sede do fornecedor, dirigidos para pedreiros, encarregados e mestres de obras visando o correto uso dos componentes nas obras;

- interação com empresas produtoras de argamassas industrializadas para assentamento dos blocos e revestimentos, objetivando o desenvolvimento de produtos específicos;

- programa promocional de especificação em escritórios de projetos.

No entanto, essas ações não se mostraram suficientes para que a empresa enfrentasse os desafios impostos, por isto, considerou que o caminho para aumentar a rentabilidade de seus negócios dependia da agregação de valor aos seus produtos e, desde então, passou a observar e estudar os mercados potenciais e as práticas usuais de comercialização de produtos, a fim de identificar oportunidades.

De seu estudo de mercado identificou que as principais formas de comercialização das vedações verticais de edifícios têm sido:

a) venda somente de componentes: esta certamente é a forma mais comum de comercialização. As empresas construtoras adquirem os componentes de alvenaria e demais insumos de diferentes fornecedores; responsabilizam-se pelos serviços de execução, seja pela contratação de mão-de-obra própria seja pela contratação subempreitada; e, eventualmente, elaboram ou contratam os projetos das alvenarias, assumindo toda a responsabilidade pelo desempenho das vedações. Enquadram-se nesse tipo de venda tanto as alvenarias tradicionais como as racionalizadas ${ }^{14}$;

b) venda como sistema de produto: o conceito de sistema de produto, recente e pouco utilizado pelo meio técnico, neste trabalho, refere-se à comercialização de uma solução construtiva na qual o serviço de aplicação é executado por terceiros, sendo que o fornecedor do produto não assume a responsabilidade pelo serviço e

\footnotetext{
${ }^{14}$ A alvenaria tradicional apresenta como características marcantes o uso intenso de insumos de baixa qualidade, domínio técnico centrado na mão-de-obra executora e elevado consumo de materiais e mão-de-obra. Na alvenaria racionalizada são utilizados materiais de qualidade superior, mão-de-obra treinada e com alta produtividade, ferramentas e equipamentos especiais e projetos de alvenaria como ferramenta de coordenação (SABBATINI, 2000a).
} 
não fornece a garantia do produto aplicado. Enquadram-se nesse tipo de venda as divisórias internas de gesso acartonado, por exemplo;

c) venda como sistema de produção: o conceito de sistema de produção é também recente e ainda menos conhecido pelo meio técnico do que o anterior. Neste trabalho, um sistema de produção refere-se a uma solução construtiva completa, fornecida por uma determinada empresa e comercializada com a garantia de desempenho do produto aplicado (SABBATINI, 2000b). Enquadram-se nesse tipo de venda os painéis pré-fabricados de fachada, por exe mplo.

A Glasser, analisando os tipos de comercialização, considerou a venda de sistema de produção como uma alternativa interessante à necessidade da empresa de aumentar a rentabilidade dos seus negócios pois, nesse tipo de venda, são agregados também os serviços. Porém, não havia qualquer pesquisa de mercado que assegurasse a existência de demanda ou mercado potencial para ofertar um novo produto a ser comercializado como sistema de produção.

No entanto, uma pequena evidência da existência de mercado para a venda de sistema de produção foi verificada quando a Glasser, no segundo semestre de 1998, propôs a um dos seus clientes a venda da 'parede pronta' e não apenas dos componentes de alvenaria como solução para a vedação vertical de um shopping center, localizado no bairro do Tatuapé no município de São Paulo.

O cliente mostrou-se bastante receptivo para essa nova forma de comercialização. Mesmo sem qualquer experiência, a Glasser comercializou os materiais e componentes necessários à execução das paredes e forneceu também a assessoria técnica para o acompanhamento da execução. Estava lançada a idéia que originaria o SVM.

No primeiro semestre de 1999, a Glasser contratou uma consultoria especializada no desenvolvimento de inovações construtivas e propôs-se a estudar o desenvolvimento de novos produtos a serem comercializados como sistemas de produção, com o propósito de oferecer ao mercado algo mais que seu produto tradicional - o bloco de concreto - para aplicação em paredes de vedação e alvenaria estrutural.

O plano de desenvolvimento desses novos produtos, inicialmente estabelecido pela Glasser, considerava três situações diferentes em função da existência de mercados 
potenciais e, principalmente, considerando-se a necessidade de aumento na rentabilidade dos negócios. As três situações consideradas foram:

- alvenaria estrutural: desenvolvimento de um sistema de alvenaria não armada para edifícios residenciais até 10 pavimentos;

- casas: desenvolvimento de um sistema de montagem a seco, através de uma nova família de blocos, com características específicas para montagem das paredes;

- vedação: desenvolvimento de um sistema de produção de alvenaria de vedação racionalizada de blocos de concreto para edifícios residenciais e comerciais com mais de 10 pavimentos.

Os novos produtos apresentam características diferenciadas entre si, considerando-se diversos fatores tais como os condicionantes de ordem técnica, os investimentos necessários e os prazos para retorno. Assim, levando-se em conta principalmente a necessidade de investimentos iniciais significativos, a Glasser avaliou que o desenvolvimento simultâneo dos três produtos não seria viável.

A empresa avaliou que a rentabilidade para as casas e edifícios em alvenaria estrutural seria maior comparada à vedação vertical; no entanto, o conjunto de condicionantes não era favorável pois implicaria nos maiores investimentos. Assim, definiu que o desenvolvimento seria iniciado pelas alvenarias de vedação e os principais fatores que influenciaram essa decisão foram:

- menores investimentos iniciais;

- não haveria prejuízos aos produtos então comercializados pela empresa frente ao novo produto que seria desenvolvido;

- possibilidade de venda em prazos reduzidos;

- margem de risco muito pequena, uma vez que não seria necessário reestruturação

- interna ou ampliação da fábrica, por exemplo;

- existência de demanda potencial para sistemas de produção de alvenaria de vedação com desempenho superior e com garantia de desempenho.

A partir dessas considerações a Glasser iniciou o processo de desenvolvimento do SVM, que será apresentado a seguir. 


\subsection{O processo de desenvolvimento}

Neste item busca-se identificar e descrever as etapas e sub-etapas do modelo utilizado pela Glasser no desenvolvimento do SVM. Vale destacar que esse modelo seguiu parcialmente a metodologia proposta por Sabbatini (1989), com algumas adaptações, sobretudo por se tratar do aperfeiçoamento do método construtivo de vedação vertical em alvenaria e com algumas variantes em função principalmente da nova forma de comercialização do SVM.

Outra observação importante é que esse processo empreendido pela Glasser não possui um registro formal, tendo sido necessária a realização de um amplo trabalho de levantamento de dados e organização das informações, como destacado no primeiro capítulo no item 1.3. O modelo, composto por dez etapas, está ilustrado na Figura 5.1 a seguir. 


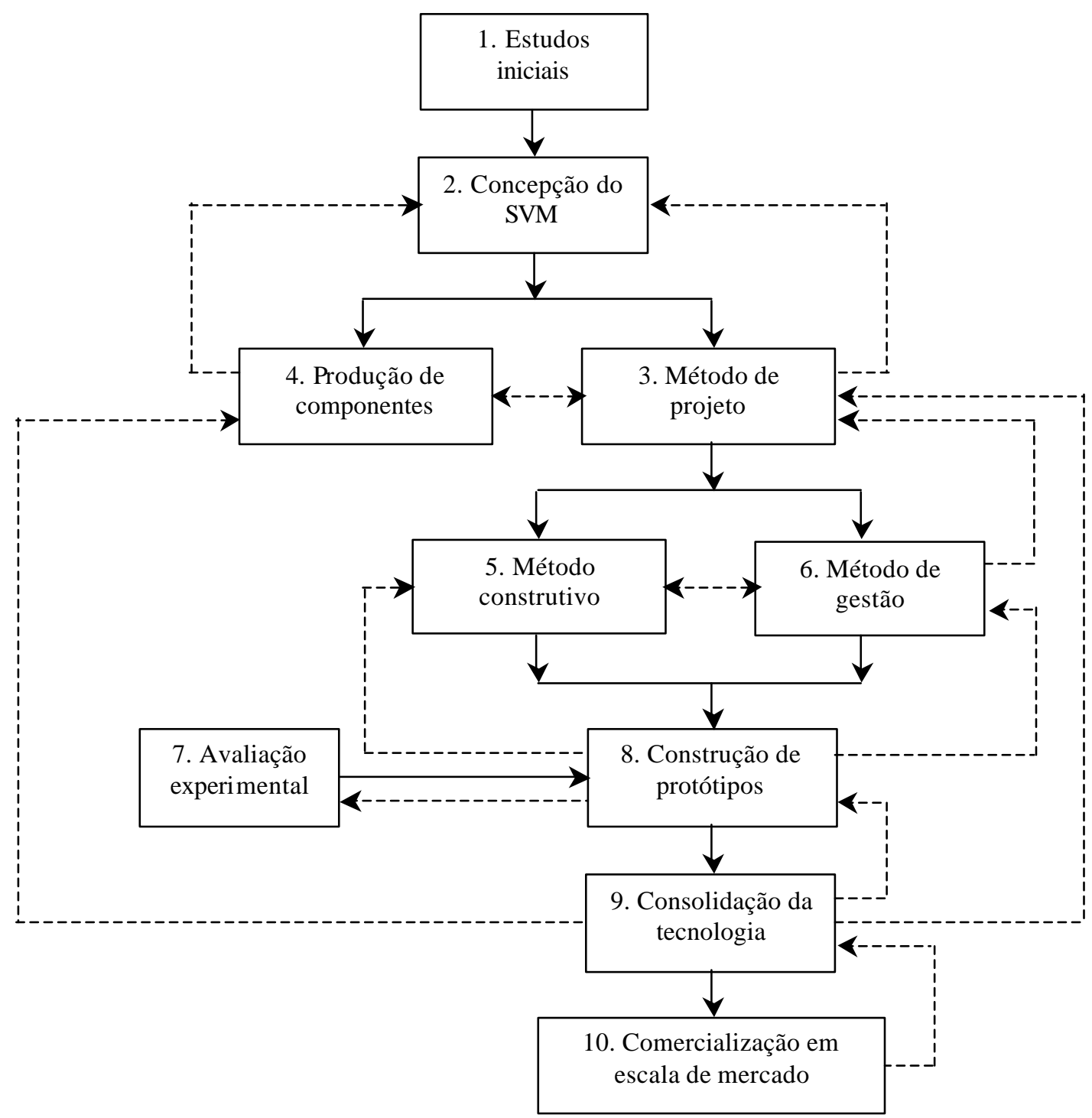

Figura 5.1 - Ilustração das etapas e ciclos iterativos do modelo de desenvolvimento do SVM.

A simbologia adotada no fluxograma da Figura 5.1 significa:

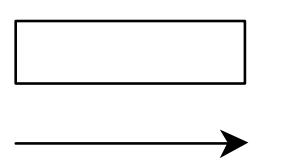

Etapa de atividade;

Linha de fluxo da sequiência cronológica;

-------- Linha de fluxo das seqüências de reatroalimentação;

<------> Linha de fluxo da seqüência de ação recíproca. 
As etapas e sub-etapas do modelo são descritas a seguir, sendo que os fluxos das subetapas não serão apresentados por considerar-se desnecessário ao escopo do trabalho o seu detalhamento ${ }^{15}$.

\subsubsection{Etapa 1 - Estudos iniciais}

Esta etapa está subdividida em sete sub-etapas:

- identificação da necessidade;

- problematização;

- análise da viabilidade técnico-econômica-financeira;

- formulação técnica do problema;

- concepção de soluções alternativas para o problema;

- análise da exeqüibilidade técnico-econômica-financeira das soluções;

- formulação do conjunto de soluções exeqüíveis.

Essas sub-etapas são apresentadas a seguir.

\subsubsection{Identificação da necessidade}

A identificação da necessidade foi um dos elementos de motivação da Glasser em se lançar a esse desenvolvimento, ou seja, a Glasser identificou como necessidades de empresas que atuam na construção de edifícios residenciais e comerciais em São Paulo a redução do custo de construção, a otimização do desempenho ${ }^{16}$ das vedações verticais e a busca por empresas especializadas para delegar a execução, com responsabilidade solidária efetiva.

\footnotetext{
${ }^{15}$ Devido à sua importância no processo de desenvolvimento de uma inovação, o fluxograma da Etapa 1 é apresentado no Anexo A. Vale destacar que esse fluxograma, proposto por Sabatini (1989), foi utilizado pela Glasser no desenvolvimento do SVM.

${ }^{16}$ A Glasser constatou que grandes empresas que atuam no mercado imobiliário que utilizavam a alvenaria de vedação em blocos cerâmicos estavam enfrentando problemas relacionados a fissuras e até mesmo ruptura das paredes causados sobretudo pelas movimentações excessivas das estruturas de concreto armado e o desempenho inadequado das alvenarias.
} 
Como resposta às necessidades identificadas, a Glasser se propunha a comercializar um sistema de produção de alvenaria de vedação, conseguindo com isto aumentar a sua rentabilidade agregando serviço com racionalidade e produtividade superior comparado ao que existe no mercado atual.

\subsubsection{Problematização}

Nesta sub-etapa o fornecedor, para melhor definir os objetivos, estabeleceu que o novo produto deveria:

a) aumentar o grau de racionalização construtiva, principalmente através da redução dos desperdícios e aumento da produtividade;

b) melhorar o desempenho das vedações, considerando-se principalmente a necessidade de recompor o equilíbrio na interface alvenaria/estrutura;

c) impulsionar a industrialização, principalmente através da aplicação do conceito de modularidade total e montagem de componentes;

d) ser comercializado com a garantia de desempenho, a fim de eliminar os problemas e conflitos com os clientes da indústria imobiliária;

e) ser comercializado com garantia de custo, prazo e qualidade, a fim de eliminar os fatores imponderáveis das outras alternativas de vedação;

f) em função das vantagens apontadas nos itens anteriores, reduzir o custo total de construção do edifício e, portanto, aumentar a eficiência da atividade imobiliária;

g) seu preço de venda deveria aumentar significativamente a rentabilidade dos negócios da empresa, para viabilizar o seu desenvolvimento.

A Glasser também identificou os fatores limitantes da inovação:

- para usufruir das vantagens da inovação são necessários projetos completos e planejamento efetivo da construção, de modo a integrá-la totalmente com a tecnologia construtiva da empresa. No entanto, as empresas construtoras em geral têm grande dificuldade no desenvolvimento adequado dessas atividades. Quanto mais cedo for a decisão de adquirir a inovação, maiores serão as vantagens obtidas, sendo ideal a contratação do fornecedor na etapa de concepção do empreendimento. No entanto, no caso das vedações verticais em alvenaria, não é 
raro que a escolha do tipo de componente seja efetuada durante a etapa de execução e, devido aos prazos reduzidos, essa condição implica em projetos incompletos e soluções não otimizadas;

- as empresas construtoras e incorporadoras, em geral, negligenciam os condicionantes de ordem técnica na escolha da vedação vertical e geralmente não apresentam a visão sistêmica necessária ao compararem as opções de vedação disponíveis no mercado. Desta forma, as vantagens econômicas potenciais do novo produto não seriam imediatamente perceptíveis por essas empresas, que geralmente analisam o custo do $\mathrm{m}^{2}$ de construção da alvenaria e não do $\mathrm{m}^{2} \mathrm{de}$ construção do edifício;

- a alvenaria de vedação apresenta interfaces com diversos subsistemas do edifício tais como a estrutura de concreto armado, revestimentos, impermeabilizações, esquadrias, instalações elétricas e hidráulicas. A comercialização da parede pronta envolve um risco devido ao desempenho da alvenaria estar condicionado ao desempenho desses outros subsistemas. As patologias freqüentemente observadas nas alvenarias de vedação ocorrem principalmente na interface com a estrutura de concreto, sendo que o grau de deformabilidade das estruturas associado às características do concreto, concepção do projeto e produção no canteiro - poderia inviabilizar a comercialização da inovação em certos casos;

- existe o preconceito, principalmente nas empresas incorporadoras, em relação à alvenaria de bloco de concreto, conforme já mencionado na nota de rodapé número 13.

Esses limitantes, majoritariamente de ordem técnica, restringiriam parte do mercado potencial identificado na sub-etapa 1 - identificação da necessidade.

\subsubsection{Análise da viabilidade técnico-econômica-financeira}

Definidos os objetivos e os fatores limitantes da inovação, o fornecedor passou a analisar a viabilidade técnico-econômica-financeira do desenvolvimento.

O fato da produção de alvenaria de vedação ser de domínio técnico da Glasser constituiu um elemento facilitador; por outro lado, os componentes da sua linha de produção não atendiam completamente às exigências do SVM relacionadas à 
modularidade. Assim, do ponto de vista técnico, seria necessário desenvolver uma nova família de componentes modulares de alvenaria.

No entanto, somente os componentes de alvenaria não constituem uma parede pronta; portanto, a Glasser viu-se obrigada a desenvolver também as argamassas para a marcação, a elevação e a fixação da alvenaria à estrutura ${ }^{17}$ que apresentasse compatibilidade com os componentes de alvenaria, inclusive adequada capacidade de absorver deformações. Esta necessidade, diferentemente da primeira, não era de domínio da Glasser, exigindo maiores investimentos.

Além disso, outros componentes também fazem parte da alvenaria de vedação e, portanto, seria necessário desenvolver elementos modulares pré-fabricados para serem utilizados nas regiões que exigem reforços na alvenaria, tais como vergas e contravergas. Deveriam ser buscadas também alternativas para otimizar a ligação das paredes com os elementos estruturais ou entre paredes.

Além dos materiais e componentes, seria necessário elaborar uma metodologia para o desenvolvimento dos projetos de alvenaria, considerando-se o desempenho e a construtibilidade como diretrizes balizadoras, conforme apresentado no item 3.1.

Finalmente, considerando-se a etapa de execução, seria necessário definir as técnicas construtivas bem como definir quem seriam os aplicadores ${ }^{18}$, a sistemática para a gestão da produção e ainda a sistemática para o planejamento e controle do processo de produção.

A Glasser avaliou a necessidade de formação de parcerias com empresas especializadas para o fornecimento dos materiais e componentes que integrariam o SVM. Então definiu que desenvolveria internamente os novos componentes modulares de alvenaria, sendo que todos os demais materiais e componentes seriam desenvolvidos por empresas parceiras.

\footnotetext{
17 A produção de alvenarias pode ser subdividida em três etapas principais: (a) marcação ou assentamento da primeira fiada de blocos, (b) elevação ou assentamento das demais fiadas de blocos e (c) fixação da última fiada de blocos à estrutura.

${ }^{18}$ Neste trabalho o termo aplicadores é utilizado para referir-se às empresas fornecedoras de mão-deobra para a execução dos serviços.
} 
Com relação aos projetos de alvenaria, avaliou a necessidade de atuar na qualificação dos principais projetistas de alvenaria de São Paulo ao invés de desenvolver os projetos internamente, por julgar que os responsáveis pelo desenvolvimento das atividades de projetos devem atuar com autonomia, com foco ms necessidades das empresas construtoras. Esses profissionais devem possuir uma visão ampla e imparcial das soluções disponíveis no mercado e do processo de produção das empresas construtoras. Além disso, considerou que os projetistas poderiam colaborar na divulgação do SVM, catalogando-o como solução para as vedações verticais de edifícios. A Glasser definiu que deveria redigir um manual contendo as diretrizes necessárias à elaboração dos projetos conforme as características do SVM e, então, atuaria na qualificação desses projetistas.

Com relação aos aplicadores, definiu que atuaria inicialmente na identificação, seleção e qualificação de empresas fornecedoras de mão-de-obra, através de treinamentos prévios e, durante a execução, através de supervisão e mo nitoramento dos resultados. Essas empresas, num determinado momento do processo de desenvolvimento do SVM, passariam a atuar como empresas credenciadas para a aplicação do SVM.

A Glasser avaliou a necessidade de organizar uma equipe interna para conduzir a gestão e controle do processo de produção, por considerar que o domínio do processo de produção do SVM deveria estar totalmente na empresa.

Quanto à viabilidade econômica, a Glasser avaliou que com a comercialização também dos serviços de execução e controle seria possível aumentar a rentabilidade do negócio de forma significativa. No entanto, o novo produto estaria inserido num mercado dominado pela alvenaria produzida com blocos cerâmicos; assim, considerando-se esse dado, a Glasser, tomando como parâmetro o preço praticado pelos fornecedores de blocos cerâmicos de qualidade superior, estabeleceu a faixa de preço do novo produto e a necessidade de ser economicamente viável.

Vale destacar que embora o mercado potencial apontasse para um grande interesse para o novo produto com desempenho superior e com garantias, o fornecedor estava consciente das dificuldades comerciais em função do custo superior do SVM comparado ao custo do $\mathrm{m}^{2}$ de construção da alvenaria tradicional. Assim, o preço do 
SVM restringiria ainda mais o mercado potencial identificado na sub-etapa 1identificação da necessidade.

Finalmente, quanto à viabilidade financeira, o fornecedor avaliou principalmente os custos envolvidos na aquisição de novos equipamentos industrias para desenvolver a nova família de componentes modulares. Avaliou também os custos necessários à contratação dos serviços de consultoria especializada e ainda os custos com a contratação de profissionais especializados necessários já na etapa inicial de desenvolvimento.

A Glasser, após concluir todas as análises necessárias, decidiu prosseguir com o desenvolvimento do SVM.

\subsubsection{Formulação técnica do problema}

As principais considerações nesta sub-etapa foram:

a) o aumento da produtividade poderia ser obtido através de uma nova família de componentes modulares de alvenaria, cuja modulação e as interfaces com outros subsistemas do edifício estariam resolvidas nos projetos de alvenaria. A produtividade também seria otimizada através do efetivo planejamento da etapa de execução e através de treinamentos e qualificação da mão-de-obra de produção;

b) a redução dos desperdícios seria obtida também através dos novos componentes modulares de alvenaria, diminuindo-se a necessidade de cortes e adaptações na etapa de execução. A qualificação da mão-de-obra de produção também reduziria o desperdício de insumos, sendo os operários treinados tanto no emprego de procedimentos adequados para a utilização dos insumos quanto na utilização de ferramentas e equipamentos específicos para a racionalização da execução. As atividades de controle da execução, programação de insumos, recebimento e estocagem dos insumos no canteiro, sob a responsabilidade da Glasser, também implicariam na redução dos desperdícios;

c) a fim de otimizar o desempenho das vedações, principalmente considerando-se a exigência de se recompor o equilíbrio na interface alvenaria/estrutura, consideroutse a necessidade de desenvolver uma argamassa de assentamento que 
implicasse em elevado desempenho da junta e, por conseqüência, da alvenaria. Essa argamassa, segundo Sabbatini (1979), deveria apresentar trabalhabilidade adequada, retenção de água adequada aos componentes de alvenaria, capacidade de aderência adequada, resistência mecânica compatível com as condições de solicitação, capacidade maximizada de absorver deformações e durabilidade compatível com a vida útil esperada. Além disso, a fim de aumentar a capacidade da alvenaria em absorver deformações, considerou-se o não preenchimento, com argamassa, das juntas verticais entre os componentes de alvenaria, alternativa tecnológica amplamente empregada pelo meio técnico e de domínio da própria empresa;

d) como a Glasser não tinha condições de produzir todos os insumos necessários para a produção da parede, para que o novo produto fosse comercializado com a garantia de custo, prazo e qualidade era necessário uma aproximação com as empresas fornecedoras dos demais insumos necessários - dispositivos metálicos para fixação da alvenaria aos elementos estruturais, argamassas e elementos préfabricados - a fim de analisar as condições técnicas e comerciais necessárias para o fornecimento desses insumos.

Vale destacar que havia algumas alternativas de fabricantes para esses materiais e componentes e integrá-los ao SVM não seria tarefa complicada ${ }^{19}$, segundo as considerações feitas pela Glasser.

A sub-etapa seguinte explora as principais considerações relacionadas aos componentes do SVM.

\subsubsection{Concepção de soluções alternativas para o problema}

Nesta sub-etapa tratourse da definição do módulo e forma dos componentes. A norma NBR5713 (ABNT, 1982) estabelece o módulo básico 20x40cm (20cm na

\footnotetext{
${ }^{19}$ Os dispositivos metálicos para a fixação da alvenaria aos elementos estruturais estavam disponíveis no mercado; os elementos pré-fabricados, embora inéditos, não constituíam grande dificuldade de fabricação havendo diversos fornecedores que tinham potencial para se tornarem parceiros; o desenvolvimento de argamassas específicas certamente seria a tarefa mais trabalhosa e que exigiria a participação de uma empresa fabricante especializada e com confiabilidade no fornecimento.
} 
direção vertical e $40 \mathrm{~cm}$ na direção horizontal) para os blocos de concreto e amarração a meio (1/2) bloco. No entanto, essa questão envolve pontos de vista diferenciados, sobretudo por influência norte americana, que utiliza o módulo 20x40cm e por influência européia, que utiliza o módulo 20x30cm para os blocos de concreto. Por ouro lado, a norma NBR5706 (ABNT, 1977) estabelece o decímetro $(\mathrm{M}=10 \mathrm{~cm})$ como módulo apropriado para a coordenação modular na construção. Desta forma, tinha-se a possibilidade de se utilizar 3M ou 4M para o módulo horizontal. A Glasser optou pela utilização do módulo 3M para o bloco inteiro e os principais argumentos da Glasser para justificar essa decisão foram:

- o módulo 3M é mais adequado para a maioria das esquadrias disponíveis no mercado;

- o módulo 3M é mais adequado para o ajuste nos vãos das estruturas convencionais de concreto armado;

- há uma tendência em se padronizar o uso do bloco de espessura nominal de $15 \mathrm{~cm}$ para as paredes de edifícios em alvenaria estrutural e, desta forma, as amarrações entre paredes seriam facilitadas com o uso do módulo 3M. Essa tendência influenciaria a utilização desse módulo também para as alvenarias de vedação;

- o módulo 3M, quando comparado ao 4M, implica em blocos mais leves e que podem levar a uma produtividade maior, considerando principalmente os fatores ergonômicos;

- os componentes de alvenaria inéditos caracterizariam o novo produto como uma inovação e, desta forma, induziriam uma vantagem relacionada ao marketing.

Definiu-se que a amarração entre os componentes seria a um terço (1/3) de $3 \mathrm{M}$ e que fariam parte da família de novos componentes de alvenaria as frações dois terços $(2 / 3)$ e um terço $(1 / 3)$ de $3 \mathrm{M}$.

$\mathrm{Na}$ direção vertical foi definido o módulo $2 \mathrm{M}$; no entanto, considerando-se a flexibilidade para eventuais ajustes nos vãos estruturais e alturas de peitoris, a Glasser definiu que seriam desenvolvidos componentes com alturas iguais a $\mathrm{M} \mathrm{e}$ $M / 2$. Definiu-se também que os novos componentes deveriam atender às três espessuras nominais convencionalmente utilizadas para a construção de alvenarias, 
sendo elas $10 \mathrm{~cm}, 15 \mathrm{~cm}$ e $20 \mathrm{~cm}$. Além disso, para permitir eventuais necessidades de ajuste horizontal bem como para permitir a recuperação da amarração a um terço $(1 / 3)$ de $3 \mathrm{M}$ na ligação das paredes de espessura nominal igual a $15 \mathrm{~cm}$, seria necessária uma peça com módulo horizontal igual a M/2.

Além dos componentes de alvenaria, a Glasser definiu a utilização de:

a) dispositivos metálicos para a fixação da alvenaria aos elementos estruturais: utilizados com a finalidade de ancoragem e reforço de ligações de paredes com elementos estruturais e entre paredes. Nesse tipo de ligação utiliza-se convencionalmente o ferro cabelo ${ }^{20}$; no entanto, recentes estudos indicam as vantagens para a racionalização da execução utilizando-se telas metálicas (FRANCO; MEDEIROS, 1999). As vantagens potenciais do uso das telas metálicas influenciaram a decisão da Glasser pela sua utilização;

b) elementos pré-fabricados para reforço tais como vergas de portas e contravergas de janelas: convencionalmente esses elementos são pré-moldados no canteiro de obra, utilizando-se sobras de concreto, aço e madeira para confecção das fôrmas, sendo sua produção definida e controlada pela equipe de obra. O fornecedor optou pela utilização de elementos pré-fabricados principalmente devido à racionalização e qualidade na produção;

c) argamassas para asssentamento e fixação da alvenaria: diversas empresas construtoras utilizam argamassas industrializadas para o assentamento da alvenaria, principalmente devido à dificuldade que têm em produzir argamassas adequadas a essa finalidade nos canteiros. A utilização de argamassa industrializada ainda proporcionaria simplificações potenciais tais como a facilidade de mistura, estocagem no canteiro e maior garantia de uniformidade de produção. A opção deu-se também em função da necessidade da participação de uma empresa especializada no desenvolvimento de uma argamassa específica aos

\footnotetext{
${ }^{20}$ Nesse tipo de ligação, na face do pilar com interface com a alvenaria, barras de aço de espera são chumbadas durante a concretagem do pilar ou então fixadas posteriormente, embutidas em furos executados com brocas de vídea, seguido de limpeza e colagem com resina epóxi ou poliéster (ABBATE, 2003). As barras são posicionadas para que fiquem ancoradas nas juntas horizontais da parede, a cada duas fiadas.
} 
componentes de alvenaria e com capacidade para o fornecimento simultâneo em diversas obras.

\subsubsection{Análise de exeqüibilidade técnico-econômica-financeira das soluções}

Considerando-se então os novos componentes de alvenaria (total de seis novas unidades) e espessuras nominais convencionais de paredes $(10 \mathrm{~cm}, 15 \mathrm{~cm}$ e $20 \mathrm{~cm})$, seriam necessárias dezoito novas fôrmas. Inicialmente imaginoutse o bloco inteiro fabricado com frisos a um terço (1/3) de $3 \mathrm{M}$ para permitir que as unidades dois terços $(2 / 3)$ e um terço (1/3) fossem geradas por seccionamento. No entanto, essa idéia não foi levada adiante pois foi considerado que essa solução poderia implicar em perdas de bloco em função do corte. Na época, a empresa produzia a fração um quarto (1/4) para a sua linha de produtos que utiliza o módulo $4 \mathrm{M}$, ou seja, uma unidade equivalente à fração um terço $(1 / 3)$ de $3 \mathrm{M}$. Além disso, a empresa produzia uma unidade maciça um oitavo (1/8) do módulo 4M. Para racionalizar a produção dos componentes a empresa decidiu substituir as frações um quarto (1/4) e um oitavo (1/8) de 4M pela fração seccionável um terço (1/3) de 3M. Foram então necessárias quinze novas fôrmas, sendo que três delas substituíram seis fôrmas existentes.

A definição da forma dos novos componentes de alvenaria implicou na definição da forma de outros componentes - principalmente telas metálicas e elementos préfabricados. Nesta etapa, a Glasser aproximou-se de alguns dos principais fornecedores de telas metálicas e de acessórios para a fixação dessas telas, elementos pré-fabricados e argamassas para avaliar a viabilidade técnica e comercial do fornecimento.

Inicialmente a Glasser considerou a possibilidade de comercializar os demais insumos (telas metálicas e acessórios para fixação dessas telas, elementos préfabricados e argamassas) através da venda por consignação junto às empresas fornecedoras. Esses componentes seriam estocados na sede da Glasser e pagos diretamente aos fornecedores parceiros à medida que fossem utilizados nas obras. No entanto, a Glasser avaliou que para diminuir os encargos, principalmente considerando-se os impostos sobre impostos, a melhor alternativa seria que esses insumos fossem faturados diretamente entre as empresas construtoras e os 
fornecedores. A Glasser, por assumir os custos de vendas desses insumos, negociou preços e condições de pagamento especiais com as empresas fornecedoras.

A Glasser aproximou-se também de empresas fornecedora de mão-de-obra para a execução de alvenarias com o propósito de avaliar os custos dos serviços e capacidade técnica dessas empresas. Finalmente estudou os custos de construção de alvenarias de algumas empresas construtoras e, então, avaliou a viabilidade econômica do SVM e concluiu que sua comercialização poderia aumentar significativamente a rentabilidade dos negócios.

\subsubsection{Formulação do conjunto de soluções exeqüíveis}

O SVM trata-se de uma solução única, cujas linhas gerais são descritas na etapa seguinte de concepção do novo produto.

\subsubsection{Etapa 2: Concepção do novo produto}

O SVM, resumidamente, deveria integrar:

- novos componentes modulares de alvenaria, considerando-se o módulo vertical 2M e módulo horizontal 3M, com possibilidade de ajuste até $\mathrm{M} / 2$ nas duas direções. Além disso, o projeto dos novos componentes deveria considerar o não preenchimento das juntas verticais;

- a argamassa de assentamento, telas metálicas, acessórios para a fixação dessas telas e elementos pré-fabricados seriam fornecidos por terceiros e desenvolvidos conjuntamente com a Glasser;

- a mão-de-obra para a execução fornecida por terceiros. Essas empresas deveriam ser qualificadas pela Glasser e os procedimentos de execução deveriam estar definidos num manual de execução;

- os projetos de alvenaria desenvolvidos por terceiros. Os projetistas deveriam ser também qualificados pela Glasser e as diretrizes para orientar o desenvolvimento das atividades de projeto das alvenarias deveriam estar definidas num manual de projeto; 
- a gestão do processo produtivo, integrando as atividades planejamento, gerenciamento e controle. Essas atividades deveriam ser conduzidas pela Glasser. Além disso, as interfaces com as instalações hidráulicas e elétricas deveriam ser planejadas a fim de reduzir os desperdícios. No caso das instalações hidráulicas, as prumadas deveriam preferencialmente ser embutidas em shafts e os ramais embutidos dentro de cortes efetuados posteriormente à execução da alvenaria, utilizando-se ferramentas apropriadas. As instalações elétricas deveriam ser embutidas nos furos dos blocos, devendo-se garantir a continuidade vertical dos furos dos blocos através da amarração a um terço (1/3) do bloco inteiro, ou seja, $10 \mathrm{~cm}$. Através do corte dos septos transversais dos blocos também seria possível o embutimento dessas instalações na direção horizontal.

No assentamento dos blocos deveria ser utilizada preferencialmente a bisnaga, a fim de reduzir os desperdícios de argamassa. Para isso seria necessário desenvolver uma argamassa com propriedades adequadas a essa técnica. As demais ferramentas e equipamentos ${ }^{21}$ também deveriam otimizar a qualidade e racionalização da execução. Para desenvolver as atividades de acompanha mento das obras e controle da execução a Glasser deveria organizar equipes próprias formadas por engenheiros, tecnólogos e técnicos.

As etapas seguintes descrevem com mais detalhes as atividades desenvolvidas pela Glasser durante o processo de desenvolvimento do SVM, sendo que as etapas 3 e 4 retroalimentaram esta etapa relativa à concepção.

\subsubsection{Etapa 3: Método de projeto}

$\mathrm{Na}$ estratégia da Glasser o projeto de alvenaria é a ferramenta básica na racionalização da produção das alvenarias. Através dos projetos de alvenaria é possível reduzir os desperdícios e obter ganhos de produtividade, sendo que nesses projetos são definidas previamente a modulação das paredes e a compatibilização dos subsistemas do edifício com interfaces com as alvenarias tais como estrutura, impermeabilização, esquadrias, revestimentos e instalações.

${ }^{21}$ A Glasser estabeleceu parceria com uma empresa especializada no fornecimento de ferramentas e equipamentos especiais, conforme será apresentado no item 5.3.5.2. 
Sobretudo através de consultoria especializada, a Glasser elaborou um manual com as diretrizes para a elaboração dos projetos de alvenaria, que foi a ferramenta utilizada para qualificar os projetistas parceiros. Indicados pelo fornecedor, os projetistas são selecionados e contratados diretamente pelas empresas construtoras.

A Glasser também atuou na qualificação dos profissionais das empresas construtoras que desenvolvem seus projetos internamente. Em todos os casos, a Glasser participa revisando os projetos, visando principalmente a otimização do desempenho das alvenarias e aspectos relacionados ao aumento da produtividade.

\subsubsection{Definição de componentes e soluções básicas de projeto}

$\mathrm{Na}$ Tabela 5.1 a seguir são apresentadas as dimensões reais e as massas dos novos componentes modulares de alvenaria definidos pela Glasser.

Tabela 5.1 - Dimensões reais e massas das unidades de alvenaria (GLASSER, 2002a).

\begin{tabular}{|c|c|c|c|c|c|c|}
\hline & $\begin{array}{c}\text { bloco } \\
\text { inteiro }\end{array}$ & $2 / 3$ & $1 / 3$ & 1/6 (*) & $\begin{array}{c}\text { canaleta } \\
\text { alta }\end{array}$ & $\begin{array}{c}\text { canaleta } \\
\text { baixa }\end{array}$ \\
\hline $\begin{array}{c}\text { Espessuras } \\
\text { nominais de } \\
10 \mathrm{~cm}, 15 \mathrm{~cm} \\
\text { ou } 20 \mathrm{~cm}\end{array}$ & & & & & & \\
\hline Larg. $(\mathrm{cm})$ & $9 / 14 / 19$ & $9 / 14 / 19$ & $9 / 14 / 19$ & $9 / 14 / 19$ & $9 / 14 / 19$ & $9 / 14 / 19$ \\
\hline Altura $(\mathrm{cm})$ & 19 & 19 & 19 & 19 & 9 & 4 \\
\hline Compr. $(\mathrm{cm})$ & 29,7 & 19,7 & 9,7 & 4,7 & 29,7 & 29,7 \\
\hline Massa (kg) & $\begin{array}{c}6,81 ; 8,49 \\
\text { e } 10,40\end{array}$ & $\begin{array}{c}4,44 ; 5,84 \\
\text { e } 7,70\end{array}$ & $\begin{array}{c}2,60 ; 3,51 \\
\text { e } 4,50\end{array}$ & $\begin{array}{l}1,30 ; 1,76 \\
\text { e } 2,25\end{array}$ & $\begin{array}{c}, 80 ; 5,50 \\
\text { e } 8,41\end{array}$ & $\begin{array}{c}1,96 ; 2,98 \\
\text { e } 3,92\end{array}$ \\
\hline
\end{tabular}

$\left(^{*}\right)$ a unidade $1 / 6$ é obtida através do secionamento da unidade $1 / 3$.

As soluções básicas de projeto contemplaram:

- a amarração a um terço (1/3) do bloco inteiro, ou seja, $10 \mathrm{~cm}$;

- como regra geral, as juntas verticais não seriam preenchidas com argamassa, a fim de aumentar a capacidade da alvenaria em absorver deformações. As juntas verticais não preenchidas teriam espessura de $3 \mathrm{~mm}$, sendo esta a diferença entre o comprimento nominal e real dos componentes de alvenaria;

- as juntas horizontais sempre preenchidas com argamassa e espessura igual a $1 \mathrm{~cm}$; 
- utilização de blocos tipo canaletas para o ajuste de altura de vãos de portas, janelas e pés direito;

- utilização da fração um sexto (1/6) do bloco inteiro para a recuperação da amarração de $10 \mathrm{~cm}$, por exemplo, de paredes de $15 \mathrm{~cm}$ de espessura nominal, conforme ilustra a Figura 5.2 a seguir.

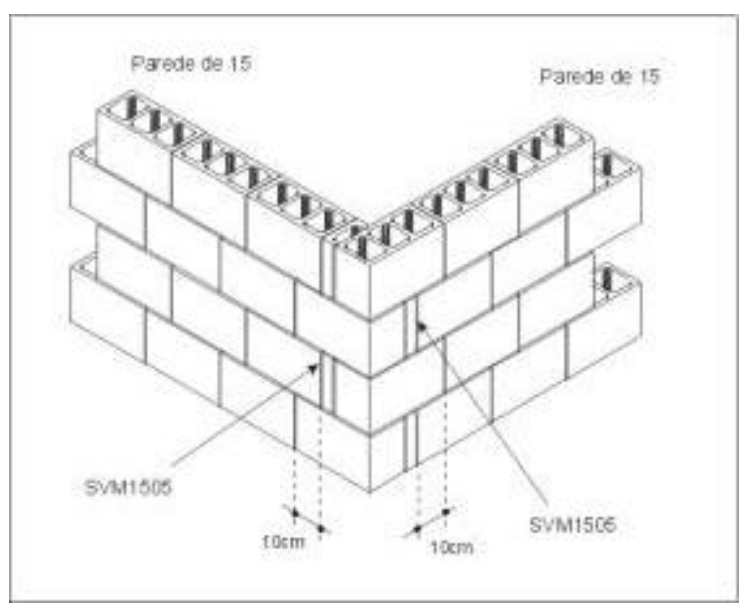

Figura 5.2 - Utilização da fração um sexto (1/6) imediatamente após a amarração de canto de parede, a fim de recuperar a amarração a $10 \mathrm{~cm}$ nas duas paredes (GLASSER, 2002a).

\subsubsection{Definição de soluções detalhadas de projeto}

Nesta sub-etapa foram definidos principalmente os critérios para orientar a decisão quanto à:

- necessidade técnica de preenchimento das juntas verticais de travamento da alvenaria;

- necessidade de utilização de telas metálicas para ancoragem e reforço da ligação da alvenaria com os elementos estruturais;

- utilização de contravergas em vãos de janelas, bem como as regras para o posicionamento desses elementos.

\subsubsection{Definição de especificações para parametrização da estrutura}

As especificações para parametrização da estrutura referem-se aos estudos necessários à avaliação das características geométricas das estruturas de concreto 
armado dos edifícios, a fim de compatibilizá-las à utilização do SVM. Além disso, essas especificações são fundamentais para fornecer os subsídios necessários à avaliação principalmente do grau de deformabilidade dessas estruturas, a fim de identificar a necessidade de reforços a serem incorporados nos projetos de alvenaria.

No manual de projetos de alvenaria do SVM são recomendadas as espessuras de vigas e pilares, adequadas às espessuras das paredes do SVM, para orientar a concepção e projeto das estruturas dos edifícios. Além disso, recomendam-se os pés direitos, alturas de vigas e peitoris preferenciais considerando-se a utilização do SVM.

Quanto à avaliação do grau de deformabilidade das estruturas, seguem algumas considerações, não somente para orientar a elaboração dos projetos de alvenaria quanto aos reforços necessários, mas também como subsídio para avaliação dos riscos envolvidos na comercialização do SVM.

Como já foi salientado, diversos subsistemas do edifício apresentam interfaces com as alvenarias de vedação e, por isto, a comercialização do SVM, com a garantia de desempenho, envolve um risco de difícil avaliação devido ao desempenho da alvenaria estar condicionado ao desempenho desses outros subsistemas.

Entre os problemas patológicos mais comuns das alvenarias de vedação, incluem-se as fissuras, trincas e até mesmo rupturas da vedação. Segundo Franco (2000), as principais causas desses problemas são os movimentos diferenciais que ocorrem nas ligações entre os elementos de concreto armado e as paredes de alvenaria, devido à maior sensibilidade da alvenaria às ações mecânicas que lhe são impostas e aos deslocamentos muitas vezes excessivos que as estruturas e seus elementos têm apresentado, sendo sua magnitude e intensidade maiores quanto maior for o grau de restrição imposto aos movimentos.

Existem algumas alternativas para evitar ou diminuir a incidência dessas patologias destacando-se: (a) a dessolidarizar a alvenaria da estrutura, (b) o aumento da rigidez da alvenaria, (c) possibilitar elevada rigidez à estrutura e (d) recompor o equilíbrio alvenaria/estrutura (SABBATINI, 1998a). O SVM adota a última delas, ou seja, a opção pela compatibilização das deformações da estrutura com a capacidade da 
alvenaria em absorvê-las, sendo que as técnicas construtivas e os componentes do SVM foram definidos considerando-se essa opção.

Tomando-se esta alternativa como parâmetro, para avaliar a viabilidade da comercialização do SVM bem como para orientar as atividades de projetos das alvenarias, a Glasser avalia a deformabilidade das estruturas de concreto armado dos edifícios através da análise de:

- dimensões dos elementos estruturais, principalmente da espessura de lajes: maior rigidez localizada é obtida com o incremento nas dimensões desses elementos;

- quantidade, dimensão e rigidez dos nós: a maior rigidez global é obtida com o aumento da quantidade, dimensão e rigidez dos nós (uso de vigas sob paredes);

- tempo de escoramento permanente e percentual de escoras permanentes: a menor deformabilidade dos elementos é obtida com o incremento do tempo de escoramento permanente (mínimo de 28 dias) e o aumento percentual de escoras permanentes;

- deformação lenta: a menor deformação lenta da estrutura de concreto é obtida incrementando o tempo de escoramento, promovendo a cura úmida e com o emprego de concreto de maior módulo de deformação aos 28 dias.

\subsubsection{Criação e consolidação de linguagem projetual específica}

Inicialmente a Glasser utilizou as convenções e padrões pré-definidos pelos seus projetistas parceiros. Depois de um certo tempo, com as experiências adquiridas na prática, a Glasser recomendou algumas alterações para facilitar a interpretação dos projetos pelas equipes de produção e controle.

Com o aumento do número de obras, ficou evidente a necessidade de uniformização da linguagem projetual, pois a quantidade de novos padrões e convenções também aumentou. A principal dificuldade para a padronização, no entanto, deve-se a que diversas empresas construtoras já têm seus padrões e convenções estabelecidos junto aos projetistas.

Até o momento da finalização desta pesquisa, a Glasser não havia consolidado uma linguagem projetual específica. 


\subsubsection{Redação de manual de projeto}

A Glasser elaborou o manual contendo as diretrizes para os projetos de alvenaria, o qual atualmente encontra-se na versão 4. Esse manual contém:

- os componentes de alvenaria do SVM: apresenta essencialmente a nomenclatura e características físicas, tais como geometria e massa, para cada um dos componentes de alvenaria;

- regras básicas quanto à modulação e amarração de paredes: para permitir o embutimento das instalações elétricas nas paredes, ou seja, a continuidade dos furos dos blocos na direção vertical, as juntas verticais devem ser amarradas a um terço (1/3) do componente básico, isto é, a 10cm. A ligação entre paredes deve ser feita preferencialmente por interpenetração, para otimizar o desempenho da alvenaria com relação à redistribuição de tensões e, além disso, a interpenetração deve ser feita preferencialmente a partir da segunda fiada. Amarrações inferiores a $5 \mathrm{~cm}$ não são permitidas e, desta forma, o manual de projeto recomenda que a modulação das paredes seja sempre definida na região da interseção com outras paredes e que os eventuais ajustes de modulação sejam feitos nas extremidades opostas às ligações. Para otimizar a etapa de execução, sempre que possível, recomenda-se utilizar as unidades básicas e dois terços (2/3) nas extremidades das paredes. Finalmente, embora seja recomendado que as ligações entre paredes sejam preferencialmente feitas por interpenetração, em alguns casos existe a possibilidade da amarração feita com as telas metálicas de ancoragem, por exemplo, nas paredes com variação de espessura, paredes de shafts ou paredes externas (ou de periferia) e paredes internas em função da seqüência de execução definida.

- tipos de juntas: as juntas são divididas em horizontais e verticais, havendo uma sub-divisão, conforme apresentado a seguir.

- juntas horizontais: estão divididas em juntas horizontais de base, de assentamento e de fixação da alvenaria à estrutura, todas preenchidas com argamassa. As juntas horizontais de base devem ter no mínimo $1,0 \mathrm{~cm}$ e no máximo $2,5 \mathrm{~cm}$ de espessura e permitem a correção de eventuais desvios da 
laje concretada; as de assentamento devem ter espessura média de $1,0 \mathrm{~cm}$ e as de fixação devem ter espessura entre 1,5 a 3,0cm;

- juntas verticais: estão divididas em juntas preenchidas e não preenchidas ou 'secas'. As juntas preenchidas dividem-se em juntas de ajuste e juntas de travamento. As juntas de ajuste, como o próprio mome diz, têm a função de ajustar a modulação das paredes aos eventuais desvios da estrutura, enquanto que as de travamento assumem funções essencialmente técnicas como, por exemplo, aumentar a rigidez da parede ou então otimizar o desempenho acústico da parede. As juntas 'secas' devem ter espessura aproximadamente igual a 3mm, permitindo que a parede acomode deformações dos componentes ou então deformações do conjunto parede/estrutura. As juntas de travamento também têm espessura de aproximadamente $3 \mathrm{~mm}$, a fm de não se perder a modulação;

- utilização, especificação e posicionamento das telas metálicas : a ligação entre pilares e paredes é feita, de uma maneira geral, por aderência da argamassa em ambas as superfícies e a ligação entre paredes através do intertravamento das mesmas. No entanto, em alguns casos, para garantir o desempenho das alvenarias, recomenda-se que essas ligações sejam reforçadas com as telas metálicas, sendo que o manual especifica os tipos de telas a serem empregadas e define as regras para o seu posicionamento.

- padronização de pés direitos: apresenta algumas configurações preferenciais, considerando-se o incremento dos níveis de racionalização, de pés direitos e alturas de vigas;

- dimensionamento de vão de janelas e regras para utilização e posicionamento de contra-vergas: apresenta algumas configurações preferenciais para as dimensões dos vãos de janelas e altura de peitoris. Apresenta também as regras para utilização das contra-vergas e as principais configurações para seu posicionamento horizontal e vertical;

- dimensionamento dos vãos de portas e utilização de vergas: apresenta algumas considerações sobre as folgas laterais e na altura, considerando as possibilidades de emprego dos batentes de madeira ou os batentes metálicos 
envolventes. Além disso, apresenta as larguras preferenciais para as dimensões dos vãos de portas e as vergas pré-fabricadas disponíveis;

- instalações elétricas e hidráulicas : apresenta algumas recomendações quanto à integração desses subsistemas com a alvenaria. As instalações são muitas vezes projetadas para serem embutidas nas alvenarias, seja através de cortes nas paredes seja através do caminhamento nos vazados dos componentes da alvenaria. No caso eletrodutos flexíveis a opção mais comum é pelo caminhamento nos vazados dos componentes de alvenaria. Para embutir os eletrodutos rígidos em geral é necessário que sejam executados cortes na alvenaria. Quanto às instalações hidráulicas, em geral, os ramais e subramais são embutidos também através de cortes na alvenaria. A disposição das prumadas de hidráulica internamente aos shafts tem sido uma solução bastante utilizada, com resultados muito satisfatórios para a racionalização da execução, além de facilitar eventual necessidade de manutenção.

\subsubsection{Etapa 4: Produção de componentes}

Esta etapa é composta por quatro sub-etapas descritas a seguir.

\subsubsection{Projeto de componentes Glasser}

Os componentes de alvenaria foram apresentados na Tabela 5.1. A Figura 5.3 a seguir ilustra a família completa de componentes de alvenaria na espessura nominal igual a $10 \mathrm{~cm}$.

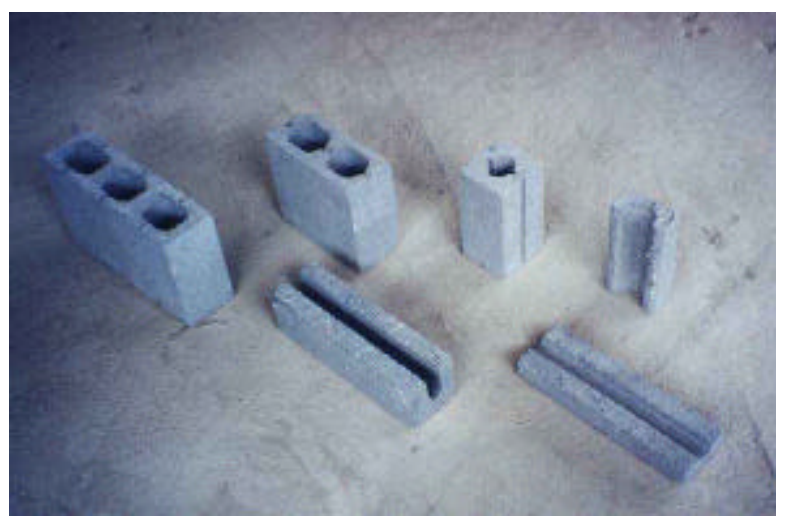

Figura 5.3 - Foto que ilustra os componentes de alvenaria do SVM para a espessura nominal igual a $10 \mathrm{~cm}$. 


\subsubsection{Projeto de outros componentes}

Para desenvolver o SVM o fornecedor adotou uma estratégia pouco comum no setor: o desenvolvimento integrado com empresas parceiras especializadas. Desta forma, o SVM contou com a colaboração de empresas fabricantes de argamassas industrializadas, de elementos pré-fabricados, de telas metálicas e acessórios para fixação dessas telas.

A seguir, apresenta-se resumidamente a contribuição das empresas parceiras, na estratégia de desenvolvimento do SVM.

a) empresa fabricante de argamassas industrializadas: o fornecedor estabeleceu inicialmente uma parceria com um fabricante de argamassas de destaque no setor. No entanto, a argamassa desenvolvida não correspondeu às expectativas da Glasser. Apesar das diversas tentativas, a parceria foi encerrada pela indefinição de uma argamassa adequada. Atualmente a Glasser mantém parceria com uma outra empresa de destaque no setor para o fornecimento da argamassa que utiliza na produção das alvenarias. No Anexo B apresentam-se as especificações técnicas da argamassa que vem sendo utilizada, até o mês abril de $2003^{22}$;

b) empresas fabricantes de telas metálicas e acessórios para fixação dessas telas: o fornecedor mantém parceria com uma empresa fabricante de telas metálicas e uma segunda empresa fabricante de acessórios para fixação dessas telas, ambas com destaque no setor quanto a capacidade de atendimento, qualidade e garantias de seus produtos. No Anexo $\mathrm{C}$ apresentam-se as características das telas metálicas utilizadas. A Figura 5.4 a seguir ilustra as telas metálicas, ferramenta e acessórios para a fixação dessas telas;

\footnotetext{
${ }^{22}$ No mês de abril de 2003 encerrou-se a coleta de dados para a realização deste trabalho.
} 

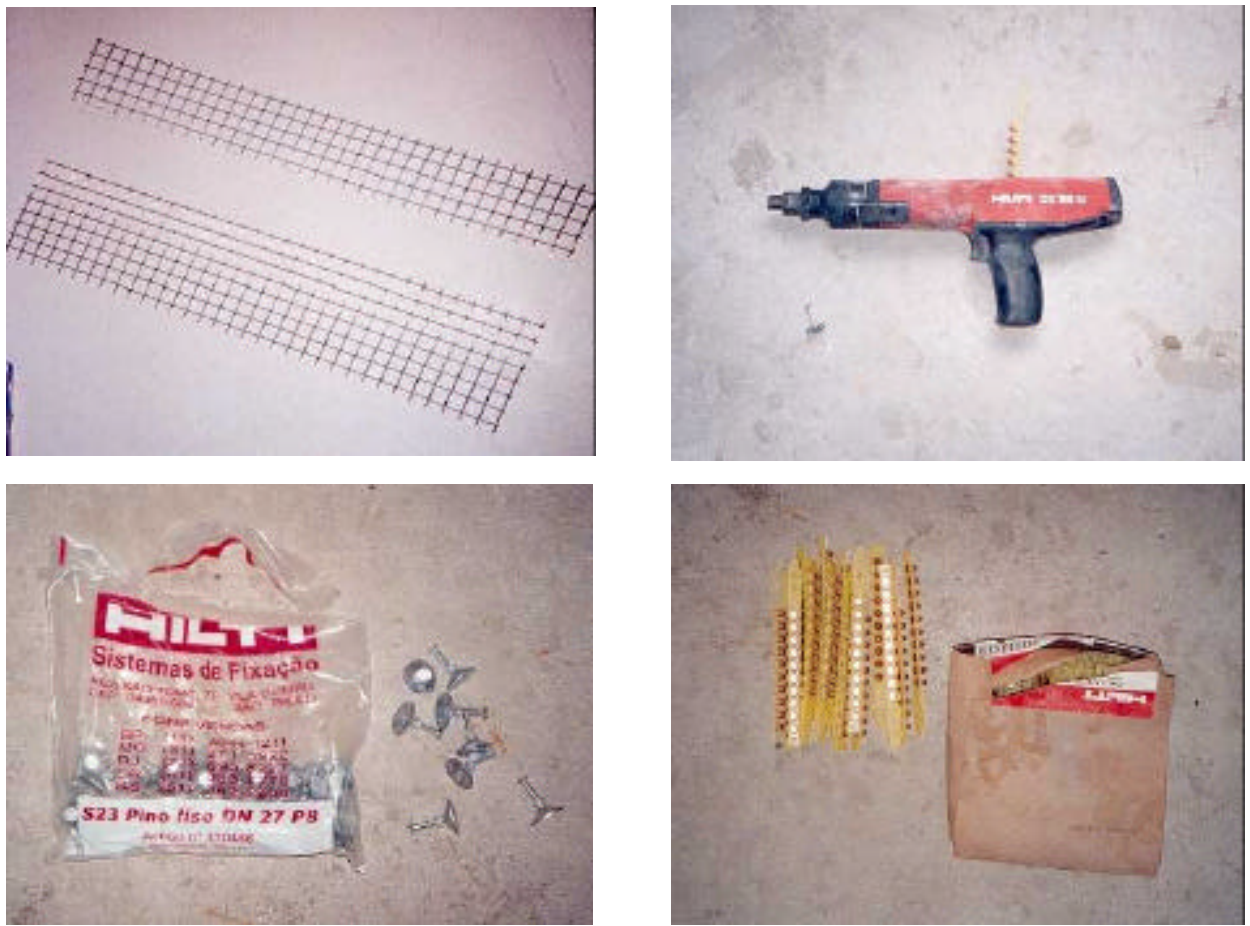

Figura 5.4 - Fotos que ilustram as telas metálicas, ferramenta e acessórios para a fixação das telas.

c) empresa fabricante de elementos pré-fabricados: o fornecedor mantém parceria com uma empresa especializada na produção de elementos préfabricados de reforço tais como vergas de portas e contravergas de janelas. No Anexo D apresentam-se as formas, dimensões e massas desses elementos. A Figura 5.5 a seguir ilustra uma verga e uma contraverga, utilizadas na produção das alvenarias.
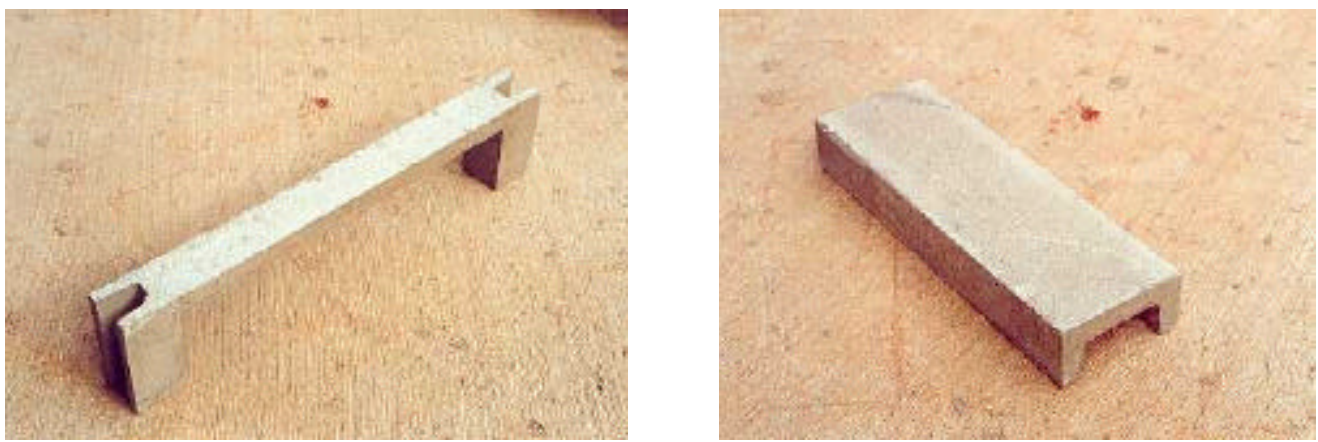

Figura 5.5 - Fotos que ilustram a verga e a contraverga empregada pelo SVM. 


\subsubsection{Formação de parcerias}

Nesta sub-etapa a Glasser estabeleceu as parcerias com as empresas fornecedoras de telas metálicas e de acessórios para a fixação dessas telas, argamassas e elementos pré-fabricados.

Essas parcerias foram formalmente estabelecidas entre os diretores da Glasser e dessas empresas. Nessas parcerias a Glasser contaria com a assistência técnica dos profissionais dessas empresas, além de condições comerciais especiais. Os fornecedores parceiros teriam seus materiais e componentes empregados nas obras comercializadas pela Glasser, ampliando o mercado de atuação e sem qualquer custo de comercialização.

\subsubsection{Produção experimental dos componentes e elementos}

A Glasser produziu experimentalmente os componentes de alvenaria assim como as empresas parceiras produziram a argamassa e os elementos pré-fabricados. A produção experimental permitiu a avaliação do processo de produção dos componentes, sendo que os ajustes necessários foram empreendidos nesta sub-etapa.

\subsubsection{Etapa 5: Método construtivo}

Esta etapa é composta por cinco sub-etapas descritas a seguir.

\subsubsection{Definição das técnicas de execução}

As técnicas construtivas são apresentadas com mais detalhes nos procedimentos de execução do SVM, organizados na forma de um manual (GLASSER, 2002b). Os principais procedimentos são aqui sintetizados.

a) aplicação de chapisco rolado: o chapisco rolado funciona como uma ponte de aderência na interface alvenaria/estrutura. Inicialmente prepara-se uma argamassa constituída por cimento e areia, misturada a uma solução de água e resina PVA ${ }^{23}$. Essa argamassa é aplicada em duas demãos nos elementos estruturais com

\footnotetext{
${ }^{23}$ A Glasser definiu previamente que os materiais utilizados na preparação da argamassa do chapisco deveriam ser fornecidos pelas empresas construtoras, pois o volume de materiais utilizado no preparo do chapisco é reduzido e esses materiais em geral estão disponíveis nos canteiros.
} 
interface com a alvenaria, previamente escovados e lavados, utilizando-se um rolo para pintura texturizada. A Figura 5.6 a seguir ilustra a aplicação do chapisco rolado;

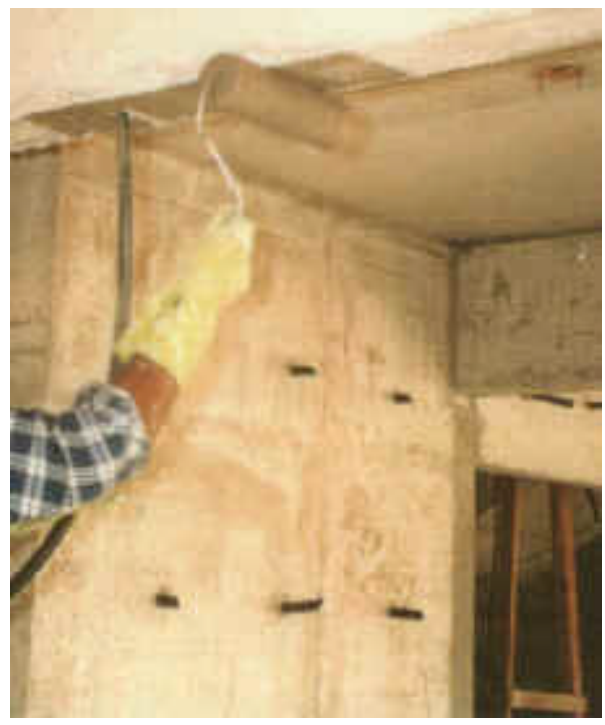

Figura 5.6 - Foto que ilustra a aplicação do chapisco rolado.

b) marcação da alvenaria: a marcação da alvenaria, ou seja, a execução da primeira fiada das paredes é executada após a conferência dos eixos do projeto e mapeamento da estrutura. O mapeamento é uma etapa na qual se identificam os eventuais desvios da estrutura de concreto armado do edifício e, então, define-se a melhor cota para o assentamento da fiada de marcação da alvenaria. A locação das paredes em relação aos eixos, tipos de blocos e tipos de juntas deve ser definida no projeto de alvenaria. A Figura 5.7 a seguir ilustra a execução da marcação da alvenaria; 


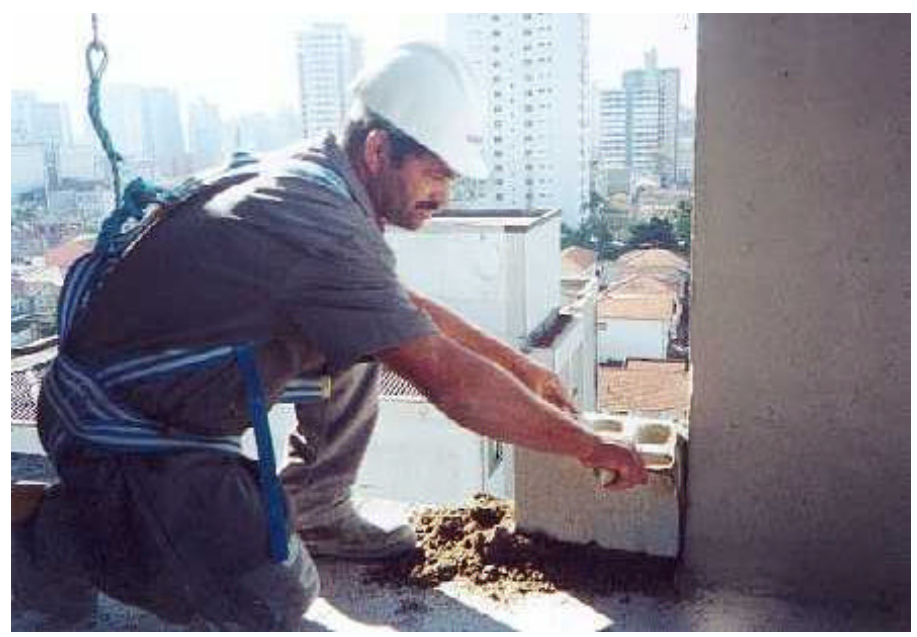

Figura 5.7 - Foto que ilustra a execução da marcação da alvenaria.

c) fixação de telas à estrutura: a fixação das telas metálicas de ancoragem das alvenarias à estrutura, prevista em projeto, é executada após a conclusão da fiada de marcação da alvenaria. As telas geralmente são fixadas entre as fiadas pares e ímpares, ou seja, a tela é posicionada dentro da junta horizontal de argamassa entre a segunda e terceira fiadas, entre a quarta e a quinta fiadas e assim por diante. A Figura 5.8 a seguir ilustra a fixação das telas metálicas à estrutura;

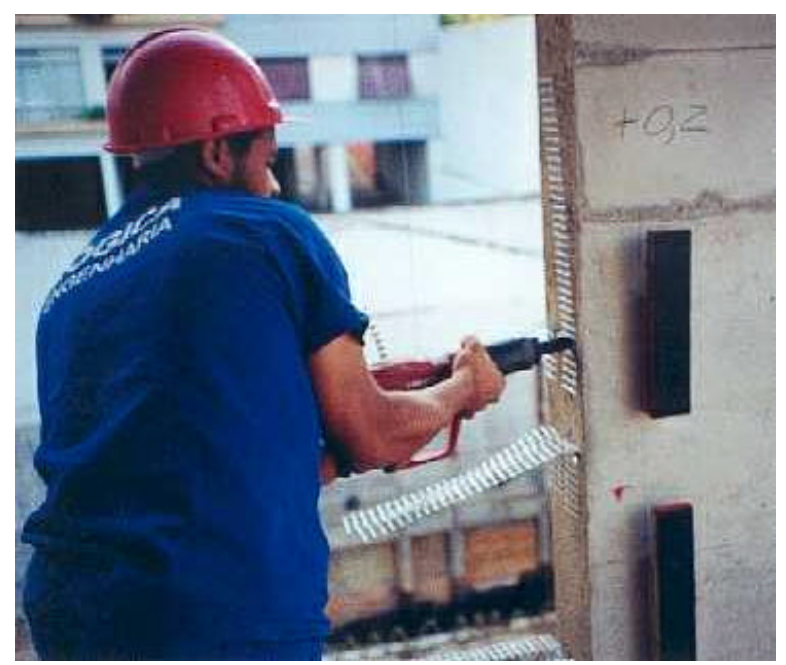

Figura 5.8 - Foto que ilustra a fixação das telas metálicas à estrutura.

d) elevação da alvenaria: após a fixação das telas à estrutura tem início a elevação da alvenaria, ou seja, o assentamento das demais fiadas de blocos. As principais ferramentas utilizadas nesta atividade são: os escantilhões metálicos utilizados principalmente como referência de prumo das paredes, alinhamento das fiadas, 
controle de espessura das juntas horizontais e definição de vãos de portas e a palheta ou bisnaga para aplicação dos cordões de argamassa. A modulação da parede, tipos de juntas e dimensões de vãos de janelas são definidos no projeto. A Figura 5.9 a seguir ilustra a execução da elevação da alvenaria;

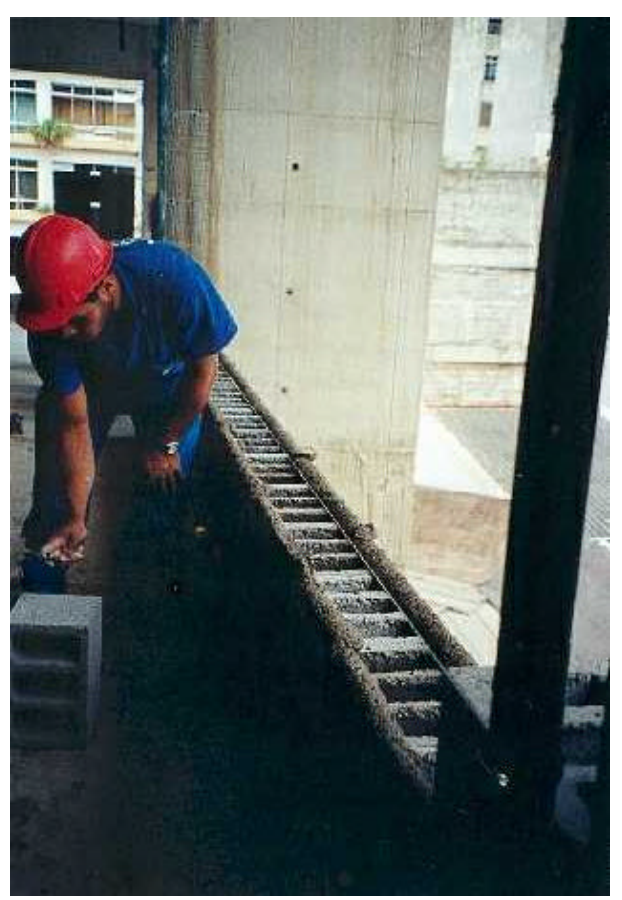

Figura 5.9 - Foto que ilustra a execução da elevação da alvenaria.

e) fixação da alvenaria à estrutura: a fixação da alvenaria à estrutura é feita utilizando-se a mesma argamassa de assentamento das fiadas. A Figura 5.10 a seguir ilustra a região de fixação da alvenaria à estrutura.

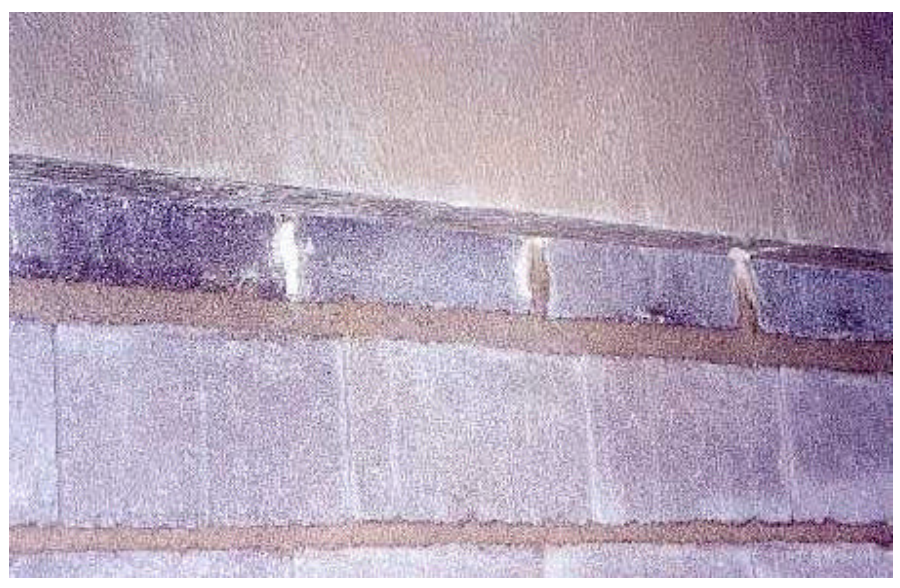

Figura 5.10 - Foto que ilustra a região de fixação da alvenaria à estrutura. 


\subsubsection{Criação e projeto de ferramentas e equipamentos}

A Glasser estabeleceu parceria com uma empresa fabricante de ferramentas e equipamentos necessários à racionalização da execução. Essa empresa colaborou com o desenvolvimento de novas ferramentas e equipamentos. Com a parceria, a Glasser negociou preços e condições de pagamento especiais para as empresas parceiras, fornecedoras de mão-de-obra.

A Glasser desenvolveu algumas ferramentas e equipamentos específicos para o SVM, tais como:

- carrinho transportador de blocos: a descarga manual de blocos exigia um equipamento específico que atendesse às características da nova família de componentes de alvenaria, sendo a principal característica a geometria do bloco inteiro - comprimento real igual a $29,7 \mathrm{~cm}$ e com três furos. Além disso, a nova família, disponível em três dferentes espessuras, requeria certa flexibilidade quanto à regulagem de altura do equipamento. A Glasser, juntamente com o fornecedor parceiro, desenvolveu um modelo protótipo com as seguintes características: base com garfo com três dentes para encaixe mo furos do bloco inteiro, regulagem de altura dessa base para permitir o encaixe nas três diferentes espessuras, abas laterais para garantir maior segurança ao operário durante o transporte e pedal de alavanca para reduzir o esforço do operário no tombame nto da pilha de blocos no corpo do equipamento. A Figura 5.11 a seguir ilustra o modelo protótipo do carrinho transportador de blocos sendo utilizado na descarga em uma das obras; 


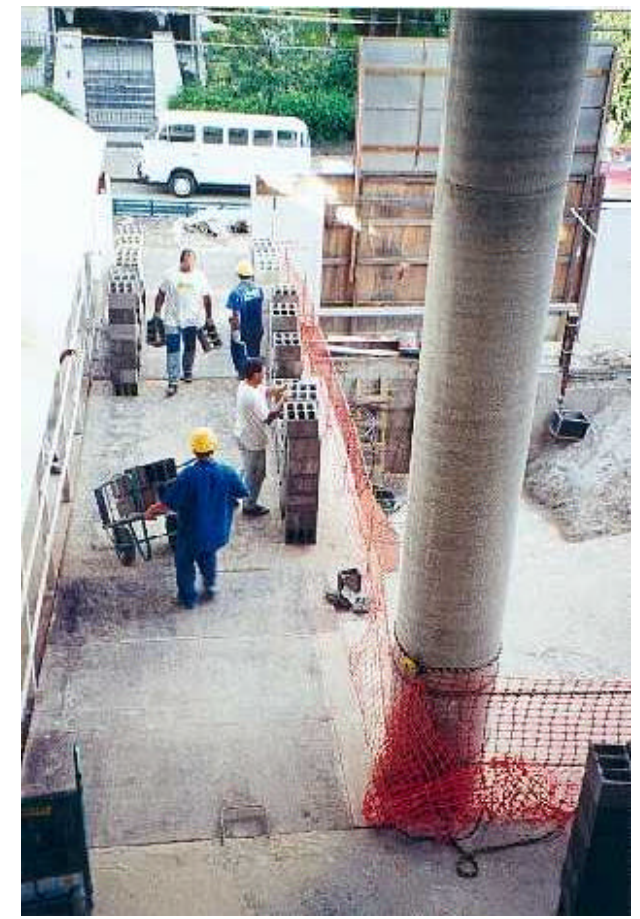

Figura 5.11 - Foto que ilustra o modelo protótipo do carrinho transportador de blocos.

- gabarito para fixação de telas metálicas: utilizado para demarcação das posições a serem fixadas as telas metálicas nos elementos estruturais, esse gabarito evita a acumulação de erros na demarcação dos pontos de fixação das telas. Por sua facilidade de confecção, com a precisão adequada e a baixo custo, esse equipamento vem sendo confeccionado nos canteiros de obras, utilizando-se sobras de madeira. A Figura 5.12 a seguir ilustra o gabarito de madeira utilizado para o posicionamento das telas metálicas; 


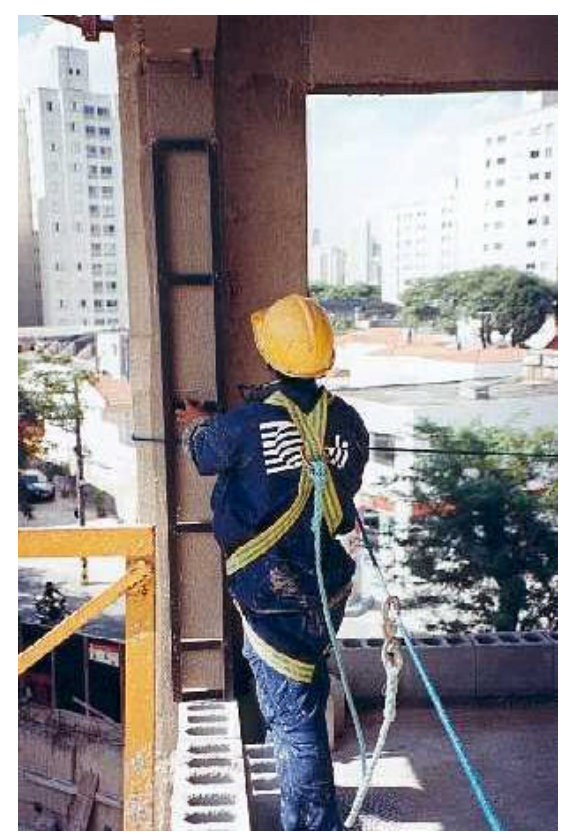

Figura 5.12 - Foto que ilustra o gabarito de madeira sendo utilizado para o posicionamento das telas metálicas.

As demais ferramentas utilizadas fazem parte da linha de produtos disponíveis no mercado para a execução de alvenarias racionalizadas.

\subsubsection{Experimentação das técnicas de execução}

As técnicas de execução foram experimentadas em campo pouco antes do início da execução da primeira obra protótipo, apresentada na etapa 7. Por aquela ocasião, a argamassa de assentamento, por suas características, inviabilizou a utilização da bisnaga pois, para obter a consistência necessária para usá-la era preciso adicionar uma quantidade de água tal que tornava uma argamassa muito fluida e incapaz de sustentar adequadamente os blocos. Desta forma, enquanto a Glasser continuava a buscar otimizar as propriedades da argamassa junto a seu parceiro, a ferramenta definida para o assentamento das fiadas foi a palheta. A utilização da bisnaga e da palheta são ilustradas na Figura 5.13 a seguir. 

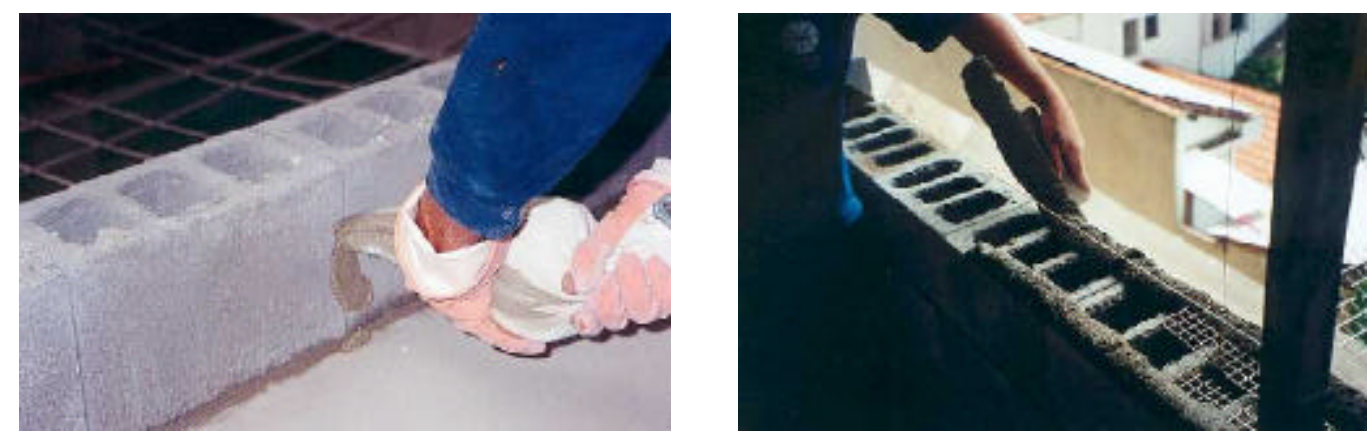

Figura 5.13 - Fotos que ilustram a bisnaga e a palheta sendo utilizadas para a aplicação de argamassa.

\subsubsection{Consolidação do método executivo}

Com a experimentação das técnicas de execução, a Glasser consolidou o método construtivo e reuniu as principais informações necessárias para a redação do manual de execução.

\subsubsection{Redação do manual de execução}

O manual de execução descreve as condições necessárias para o início dos serviços, os procedimentos de execução e a sistemática e os parâmetros para efetuar o controle do processo de execução para cada uma das atividades listadas abaixo:

- descarga e estocagem de componentes;

- aplicação de chapisco rolado;

- preparo da argamassa de marcação, assentamento e fixação;

- marcação da alvenaria;

- fixação das telas metálicas à estrutura;

- elevação da alvenaria;

- fixação da alvenaria.

O manual de execução vem sendo continuamente atualizado para agregar principalmente qualidade e produtividade aos serviços desenvolvidos, através das experiências adquiridas nas obras executadas. 


\subsubsection{Etapa 6: Método de gestão}

Esta etapa estava originalmente subdividida em cinco sub-etapas: (a) criação de metodologia de planejamento da produção, (b) criação de metodologia de gerenciamento da produção, (c) criação de metodologia de controle, (d) consolidação da metodologia de gestão do sistema e (e) redação do manual de planejamento, gestão e controle da produção.

Conforme o conceito de metodologia estabelecido por Sabbatini (1989), o processo decisório nas três primeiras sub-etapas deveria ser orientado por filosofias e diretrizes balizadoras. No entanto, a Glasser iniciou a comercialização do SVM sem a criação das metodologias previstas nessas três sub-etapas iniciais, sendo que definiu alguns métodos que seriam aperfeiçoados a partir das experiências práticas.

As duas últimas sub-etapas, consolidação da metodologia de gestão do sistema e redação do manual de planejamento, gestão e controle da produção, não foram concluídas até o momento de finalização da presente pesquisa.

\subsubsection{Criação de método de planejamento}

As atividades macro do planejamento são:

- a definição das frentes de serviços;

- a definição do cronograma de execução dos serviços;

- o dimensionamento das equipes da Glasser responsáveis pelo controle da produção;

- o levantamento dos insumos necessários e a programação para a fabricação desses insumos.

Antes do início da execução dos serviços, um engenheiro da Glasser realiza uma ou mais visitas ao canteiro de obra, a fim de levantar sobretudo as informações necessárias ao planejamento da produção, buscando-se identificar principalmente os prazos de execução do edifício, os ciclos de produção da estrutura e também os prazos para execução dos demais serviços com interface com a alvenaria e, finalmente, a seqüência de liberação de frentes de serviços. 
Nessas visitas, esse engenheiro da Glasser apresenta ao engenheiro residente da obra os elementos que devem ser disponibilizados pela empresa construtora para que os serviços de alvenaria possam ser iniciados, tais como as instalações para receber os operários, os sistemas de abastecimento de água e energia elétrica, o equipamento de transporte vertical e o período de tempo em que será utilizado e os locais de acesso, descarga e estocagem dos insumos. Esses elementos estão listados na forma de um check list numa planilha que vem sendo utilizada pela Glasser denominada 'Recomendações para Início dos Serviços de Alvenaria', apresentada no Anexo E.

A partir da análise de todos esses condicionantes e das carências ${ }^{24}$ exigidas pela Glasser para o início da execução das alvenarias é definido conjuntamente, entre Glasser e a empresa construtora, o cronograma para a execução dos serviços, em que são estabelecidos os prazos e também a seqüência de produção. A partir do cronograma definido, o aplicador parceiro dimensiona as equipes de produção e a Glasser dimensiona sua equipe responsável pelo controle da produção.

Por outro lado, a partir dos projetos de alvenaria do edifício, a Glasser faz o levantamento dos insumos necessários a fim de planejar a sua fabricação desses insumos tanto internamente, considerando-se os componentes de alvenaria, quanto externamente junto aos fornecedores parceiros, considerando-se os demais componentes. Quanto maior o volume de insumos necessários, mais detalhado deverá ser o planejamento para a fabricação.

Tendo-se em mãos o cronograma e as quantidades estimadas de insumos é possível definir adequadamente as quantidades e prazos de entrega para cada um dos componentes.

No entanto, a Glasser vem enfrentando diversas dificuldades que interferem diretamente nas atividades de planejamento. A principal refere-se aos atrasos no início dos serviços por diversos motivos tais como a demora nos acertos comerciais e assinatura dos contratos e os atrasos na conclusão dos projetos de alvenaria. Essas e

\footnotetext{
${ }^{24}$ No manual com os procedimentos de execução do SVM recomenda-se o cumprimento de prazos mínimos, chamados prazos de carências, para o início dos serviços de execução das alvenarias, subdivididos basicamente em marcação, elevação e fixação da alvenaria à estrutura. As carências visam otimizar o desempenho das alvenarias.
} 
outras dificuldades serão discutidas no tem 5.3.10.6, referente à comercialização do SVM em escala piloto.

\subsubsection{Criação de método de gerenciamento da produção}

Nesta sub-etapa estava originalmente previsto o desenvolvimento de diversas atividades tais como a criação de uma documentação específica, definição de cargos e funções, procedimentos de gestão e adaptação de software para gestão e consolidação da sistemática de gestão da produção. No entanto, assim como na subetapa anterior, a Glasser iniciou a comercialização do SVM antes da conclusão dessas atividades.

A Glasser definiu que o gerenciamento da produção seria coordenado pelo diretor comercial, principalmente em função da sua experiência. No entanto, era necessário estruturar uma equipe responsável para atuar diretamente nas obras. Então, estabeleceu inicialmente que essa equipe seria formada por engenheiros, tecnólogos e técnicos. Os primeiros coordenariam diversas obras simultaneamente e supervisionariam um grupo de tecnólogos e técnicos, os quais atuariam em tempo integral nas obras.

Os técnicos e tecnólogos atuariam principalmente nas atividades de controle da execução, questão que será tratada na próxima sub-etapa. Além disso, seriam responsáveis pelo levantamento das áreas de paredes executadas, pelo recebimento de insumos e também pelo acompanhamento dos estoques e consumo durante a execução dos serviços.

Os engenheiros seriam responsáveis pela programação dos insumos, medições de serviços junto à empresa construtora, controles físicos e financeiros das obras e documentação dos resultados obtidos.

No entanto, os cargos e funções das equipes de obra inicialmente definidas pela Glasser sofreram algumas alterações durante a comercialização do SVM, por diversos motivos. Atualmente essas equipes são compostas por estagiários de nível secundário ou superior que recebem treinamento para atuarem como técnicos, em tempo integral nas obras. Esses técnicos são supervisionados diretamente por 
tecnólogos, os quais geralmente supervisionam aproximadamente cinco obras simultaneamente e são coordenados por engenheiros.

As principais atividades que vêm sendo desenvolvidas pela Glasser no gerenciamento da produção são:

- apontamento dos insumos consumidos na obra e das áreas executadas: a

Glasser avalia continuamente durante a execução a evolução dos serviços executados (medidos em $\mathrm{m}^{2}$ ) frente aos insumos consumidos (medidos em $\mathrm{R} \$$ ). Vale destacar que a Glasser assume a responsabilidade por eventuais perdas e a análise da relação $\mathrm{R} \$ / \mathrm{m}^{2}$ vem sendo utilizada pela Glasser para avaliar os desvios entre os consumos projetado e real;

- medição de serviços: o faturamento de serviços é efetuado diretamente entre a empresa contratante e a empresa fornecedora de mão-de-obra, no entanto, a Glasser responsabiliza-se contratualmente pelos serviços fornecidos e, desta forma, também gerencia os serviços executados, participando efetivamente das medições desses serviços junto à empresa contratante;

- reajuste de preço: as condições de reajuste de preço são estabelecidas no contrato, sendo que insumos e serviços são tratados isoladamente e, em geral, reajustados em momentos diferentes e aplicando-se índices diferentes (mão-deobra reajustada conforme dissídio coletivo da categoria e insumos conforme negociações com o contratante). Os índices de reajustes e as quantidades a reajustar são acompanhados pela Glasser juntamente com a empresa contratante;

- saldos e fechamento de contrato: após a conclusão dos serviços, a Glasser apresenta à empresa contratante um balanço com os saldos contratuais para efeito de fechamento de contrato, calculados a partir das áreas executadas, preço unitário estabelecido contratualmente e desembolso com insumos e serviços. Por assumir a responsabilidade por perdas a Glasser assume quaisquer custos adicionais.

A atividade de apontamento dos insumos consumidos na obra inicia-se com a programação de um insumo, que é feita utilizando-se a planilha 'Programação de Materiais', apresentada no Anexo F. A programação é definida pelo tecnólogo ou 
engenheiro, sendo que essa planilha é preenchida e então encaminhada ao fornecedor parceiro.

O estagiário da Glasser recebe o insumo programado e anexa a quarta via da nota fiscal desse insumo à planilha de programação, sendo que as demais vias são encaminhadas para o responsável administrativo da obra, uma vez que os insumos são faturados diretamente pela empresa contratante. O estagiário da Glasser então preenche a planilha 'Controle de Recebimento', apresentada no Anexo G, e arquiva a quarta via da nota fiscal.

Em geral o engenheiro da Glasser transfere os dados da planilha 'Controle de Recebimento' para uma planilha eletrônica e então analisa, frente aos saldos de contrato e às previsões de orçamento, os consumos e os custos de cada um dos componentes que integram o SVM.

A principal dificuldade na atividade de apontamento dos insumos consumidos na obra tem sido a falta de agilidade no processamento dos dados das planilhas 'Controle de Recebimento', ou seja, a passagem dos dados da planilha manual para a planilha eletrônica. Essa atividade é desenvolvida geralmente mensalmente e exclusivamente na sede da empresa, pois não há disponibilidade de computadores nas obras, o que resulta em tempo excessivo para que se tenha retorno.

Quanto à medição de serviços, a Glasser utiliza duas planilhas administrativas. A planilha 'Levantamento de Áreas', apresentada no Anexo H, é preenchida pelo estagiário da Glasser e é utilizada para levantar as dimensões das paredes executadas, inclusive as dimensões de vãos. Os dados dessa planilha também são transferidos para uma planilha eletrônica e os cálculos das áreas executadas são efetuados automaticamente.

A medição dos serviços executados, geralmente efetuada pelos tecnólogos e engenheiros, é feita a partir das áreas totais de paredes executadas e a Glasser vem utilizando a planilha 'Acompanhamento e Medição de Serviços', apresentada no Anexo I. Essa planilha é apresentada ao engenheiro residente da obra e, após a verificação e aprovação dos valores, é encaminhada pela Glasser para o aplicador parceiro, para que este emita a nota fiscal relativa aos serviços executados. Essa atividade vem sendo desenvolvida pela Glasser sem qualquer dificuldade. 
As questões que envolvem o reajuste de preço e fechamento de contrato são geralmente conduzidas pelo diretor comercial da Glasser, conforme os compromissos estabelecidos no contrato e também em função das informações e dados das obras, que são de responsabilidade do engenheiro e do tecnólogo da Glasser responsáveis pelo acompanhamento da obra. O reajuste de preço de serviços é geralmente aplicado conforme o dissídio da categoria. O cálculo de reajuste de preço de materiais geralmente é efetuado após a conclusão dos serviços, juntamente com o fechamento de contrato.

O fechamento de contrato refere-se ao fechamento da conta corrente estabelecida entre a Glasser e a empresa contratante, ou seja, os valores dos insumos recebidos pela obra são abatidos dos saldos contratuais e, no final dos serviços, havendo débito a Glasser deve reembolsar a empresa contratante.

Vale destacar que os saldos contratuais estão vinculados à qua ntidade de serviços, em termos de $\mathrm{m}^{2}$ de parede executada. Desta forma, durante o desenvolvimento dos serviços avalia-se se as áreas estimadas são suficientes para a execução dos serviços ou se há necessidade de acréscimo de áreas às quantidades previstas.

Na maioria das obras comercializadas pela Glasser, os saldos contratuais estimados foram suficientes para a execução dos serviços. Nas demais obras onde o saldo não foi suficiente o principal motivo foi o acréscimo de áreas e, portanto, a necessidade de adendo nas quantidades contratuais.

\subsubsection{Criação de método de controle da produção}

Nesta sub-etapa estava originalmente previsto o desenvolvimento de diversas atividades tais como a redação de procedimentos de controle, desenvolvimento de software para gestão do controle e consolidação da sistemática de controle da produção. No entanto, assim como nas sub-etapas anteriores, a Glasser iniciou a comercialização do SVM antes da conclusão dessas atividades. Esta sub-etapa envolve principalmente as atividades de controle da execução; no entanto, envolve também as atividades de reprojeto e avaliação pós entrega.

Anteriormente às atividades de controle da execução vale destacar que a Glasser realiza um treinamento expositivo dirigido às equipes de produção no canteiro de 
obras, antes do início dos serviços. Neste treinamento são apresentados os componentes, os procedimentos de execução, os objetos e os métodos de controle e as tolerâncias para a aceitação dos serviços.

Vale ressaltar que a Glasser considerou originalmente a idéia do auto-controle das equipes de produção, ou seja, os próprios operários controlando a execução dos seus serviços, sem a necessidade da intervenção de encarregados ou mestres. Para isto a Glasser deveria atuar intensivamente no treinamento dos operários dos aplicadores parceiros, de forma a motivá-los e capacitá-los a essa nova forma de trabalho e, além disso, deveria atuar na supervisão e monitoramento dessas equipes nas obras.

No entanto, esse objetivo não foi alcançado por dois motivos principais. Primeiro, a Glasser não investiu na formação de uma equipe específica para treinamento, supervisão e monitoramento das equipes de produção. Para ocupar esse vazio, a atividade de treinamento das equipes de produção antes do início dos serviços foi assumida pelos engenheiros e tecnólogos; no entanto, a supervisão e monitoramento dessas equipes não têm sido realizados de forma sistemática. Segundo, as interferências e dificuldades diversas no dia-a-dia das obras tornavam necessários os encarregados e mestres ${ }^{25}$.

Nas obras onde o SVM tem sido comercializado, o controle da execução é realizado principalmente pelo tecnólogo da Glasser e os dados para esse controle são coletados diariamente por um estagiário da Glasser, através do preenchimento das planilhas de controle, apresentadas no Anexo J. Essas planilhas são utilizadas para controlar a execução dos serviços de marcação, elevação e fixação das alvenarias, sendo aplicadas em três momentos diferentes para cada um desses serviços, conforme descrito a seguir:

a) controle de liberação para início dos serviços : esse controle é aplicado antes do início dos serviços e objetiva a verificação das condições necessárias para liberação para início do serviço, antecipando eventuais interferências que poderão comprometer a qualidade da parede e a produtividade dos operários. Tais

\footnotetext{
${ }^{25}$ Nas diversas obras de diversas empresas construtoras nas quais o SVM vem sendo comercializado é comum observar dificuldades tal como se fazer respeitar os horários para utilização dos equipamentos de transporte vertical, interferindo no abastecimento de insumos nas frentes de serviço.
} 
condições envolvem a disponibilidade dos projetos de alvenaria, infra-estrutura básica (abastecimento de água e energia, disponibilidade de equipamento de transporte vertical, entre outros), insumos, ferramentas e equipamentos e atendimento às carências;

b) controle do processo: nesse controle verificam-se visualmente, durante a execução, se as equipes de produção estão utilizando corretamente os projetos, equipamentos e ferramentas e se os serviços estão sendo executados em conformidade com procedimentos de execução. Portanto, o objetivo principal do controle do processo é corrigir eventuais não conformidades durante a execução. Além disso, algumas técnicas construtivas e atividades tais como a utilização de telas metálicas na ligação das paredes com a estrutura e o adequado preenchimento com argamassa das juntas verticais na interface com a estrutura somente podem ser verificadas durante a execução;

c) controle especial de aceitação: nesse controle verifica-se, após a execução, se as propriedades da parede tais como prumo e planicidade atendem a critérios de aceitação pré-estabelecidos. O controle especial de aceitação é aplicado obrigatoriamente nos dois primeiros pavimentos executados e o tamanho da amostra é $100 \%$, ou seja, todas as paredes executadas são avaliadas. Caso o segundo pavimento seja aceito sem restrições passa-se a aplicar o controle normal de aceitação, apresentado a seguir;

d) controle normal de aceitação: nesse controle o tamanho da amostra para alguns objetos de controle é reduzida para 50\%. No caso do tamanho de amostra igual a $50 \%$, a escolha das paredes a verificar é efetuada aleatoriamente.

No controle de aceitação as providências quanto ao tratamento das não conformidades dependem da seguinte classificação:

- retrabalhar: implica que a não conformidade poderá ser corrigida pontualmente, não havendo a necessidade de desfazer toda a parede;

- retificar: implica que a não conformidade será retificada numa outra etapa, por exemplo, na aplicação dos revestimentos; 
- sucatear: implica que a parede deverá ser desfeita por completo, não havendo aproveitamento nem mesmo parcial.

Esses controles são os indicadores da efetividade do treinamento das equipes de produção e da necessidade de intensificação do controle e realização de novos treinamentos. Devido principalmente à rotatividade da mão-de-obra os treinamentos vêm sendo aplicados periodicamente pela Glasser.

Quanto ao reprojeto, geralmente após a execução do primeiro pavimento é realizada uma reunião no canteiro de obras, envolvendo o projetista, o engenheiro e o tecnólogo da Glasser e o engenheiro residente e o engenheiro coordenador de obra da empresa construtora. O objetivo da reunião é identificar falhas no projeto ou na execução e discutir soluções potencialmente vantajosas para ambos, ou seja, resolver eventuais problemas de compatibilização de subsistemas, adicionar detalhes construtivos ou melhorar os existentes e identificar alternativas potenciais para racionalizar a etapa de execução e otimizar a qualidade dos serviços. Como resultado dessa reunião, os projetistas têm efetuado a revisão do projeto, isto é, o reprojeto.

Finalmente, após a conclusão dos serviços de alvenaria, a Glasser tem mantido o contato com os responsáveis pelas obras e diretores das empresas construtoras a fim de avaliar o desempenho das alvenarias pós entrega. A Glasser fornece a assistência técnica para diagnosticar eventuais problemas patológicos e, em se verificando que a origem desses problemas está nas alvenarias executadas, assume a responsabilidade pela correção dessas patologias. A avaliação pós entrega realimenta o processo de produção com informações úteis para otimizá-lo.

Estavam previstas mais duas sub-etapas para conclusão da etapa 6, sendo uma delas a consolidação do método de gestão do sistema e a outra, a redação do manual de planejamento, gestão e controle. Essas sub-etapas não tinham sido concluídas até o momento em que se concluiu o levantamento de dados para esta pesquisa.

\subsubsection{Etapa 7: Avaliação experimental}

Nesta etapa estava previsto o estabelecimento de três convênios para a avaliação experimental do SVM. Tais convênios deveriam ter ocorrido entre a Glasser e: 
- a Escola politécnica da Universidade de São Paulo - EPUSP: com o objetivo de avaliar o desempenho do SVM através da caracterização dos componentes de alvenaria, da argamassa de assentamento e da alvenaria na forma de prismas;

- o Instituto de Pesquisas Tecnológicas de São Paulo - IPT: com o objetivo de estudar o desempenho do SVM quanto sua resistência ao fogo e também o seu desempenho acústico;

- a Associação Brasileira de Cimento Portland - ABCP: com o objetivo de obter o Selo de Qualidade, discutida no item 5.1, também para os componentes de alvenaria do SVM.

Os convênios com a Associação Brasileira de Cimento Portland - ABCP e o Instituto de Pesquisas Tecnológicas de São Paulo - IPT não tinham sido estabelecidos até o momento em que se concluiu o levantamento de dados para esta pesquisa.

O convênio de desenvolvimento tecnológico estabelecido entre a Glasser e a Escola Politécnica da Universidade de São Paulo, avaliou o desempenho da inovação através da caracterização dos componentes de alvenaria, da argamassa de assentamento e da alvenaria na forma de prismas (EPUSP/GLASSER-01, 2000); no entanto, o projeto de pesquisa não foi totalmente concluído. O principal motivo da interrupção foi a indefinição da argamassa de assentamento, adequada às necessidades de produção da alvenaria que, na época, estava sendo desenvolvida por uma empresa parceira da Glasser. Diversos ensaios foram realizados no laboratório do Departamento de Engenharia de Construção Civil da Escola Politécnica da Universidade de São Paulo. Os ensaios realizados podem ser subdivididos em três grupos.

a) caracterização dos componentes de alvenaria: caracterização geométrica dos componentes, ensaio de absorção dos blocos e ensaios de resistência à compressão;

b) caracterização da argamassa de assentamento: caracterização no estado plástico ou fresco e caracterização no estado endurecido;

c) caracterização de prismas: ensaio de resistência de aderência à tração na flexão, ensaio de resistência à compressão e ensaio de módulo de deformação. 
As normas e parâmetros que orientaram a realização desses ensaios bem como os resultados obtidos não fazem parte do escopo do trabalho e por essa razão não são aqui apresentados ${ }^{26}$.

Nesta etapa também estava inicialmente prevista a redação do manual de características físico-mecânicas do SVM, que também não foi concluído até o momento em que se concluiu o levantamento de dados para esta pesquisa.

\subsubsection{Etapa 8: Construção de protótipos}

Esta etapa é composta por duas sub-etapas descritas a seguir.

\subsubsection{Contratação e projeto de vedações em edifícios protótipos}

A Glasser definiu que seriam executadas três obras protótipos e ofereceu o SVM a três empresas construtoras com perfis diferentes, sendo que, originalmente, essas empresas utilizavam o bloco cerâmico para a vedação vertical de seus empreendimentos. Uma delas trabalha com mão-de-obra própria para a produção das alvenarias. A outra subcontrata a mão-de-obra, geralmente pouco qualificada para a execução das alvenarias. A terceira empresa trabalha com mão-de-obra subcontratada e qualificada. A comercialização do SVM nessas obras teve como objetivo principal o aprendizado prático e a consolidação do SVM como um sistema de produção de alvenaria.

Para viabilizar a comercialização do SVM nas obras protótipos, a Glasser propôs a essas empresas que apresentassem seus custos com as alvenarias que vinham utilizando para que o preço do SVM fosse negociado no mesmo patamar. Desta forma, para cada obra foram acordadas condições diferentes, sendo que em duas delas somente os insumos foram comercializados e na empresa que utiliza mão-deobra subcontratada pouco qualificada a Glasser comercializou também os serviços de execução.

Os projetos de alvenaria de duas obras foram contratados pelas empresas construtoras diretamente dos projetistas parceiros da Glasser, sendo que uma das empresas construtoras desenvolveu o projeto de alvenaria internamente.

${ }^{26}$ Detalhes desse desenvolvimento podem ser obtidos em EPUSP/Glasser-01, 2000. 


\subsubsection{Construção das vedações em edifícios protótipos e implantação das técnicas executivas e de gestão}

As características de cada uma das três obras protótipos executadas, aqui denominadas de empreendimentos PA, PB e PC, são apresentadas brevemente a seguir.

- empreendimento PA: edifício residencial localizado no bairro da Santa Cruz, zona sul da cidade de São Paulo, ilustrado na Figura 5.14 a seguir, com dezessete pavimentos-tipo, sendo quatro apartamentos por andar; estrutura convencional de concreto armado e ciclo de produção de um pavimento-tipo por semana; vedações verticais internas e externas utilizando o SVM como método construtivo e aproximadamente $10.500 \mathrm{~m}^{2}$ de área de alvenaria;

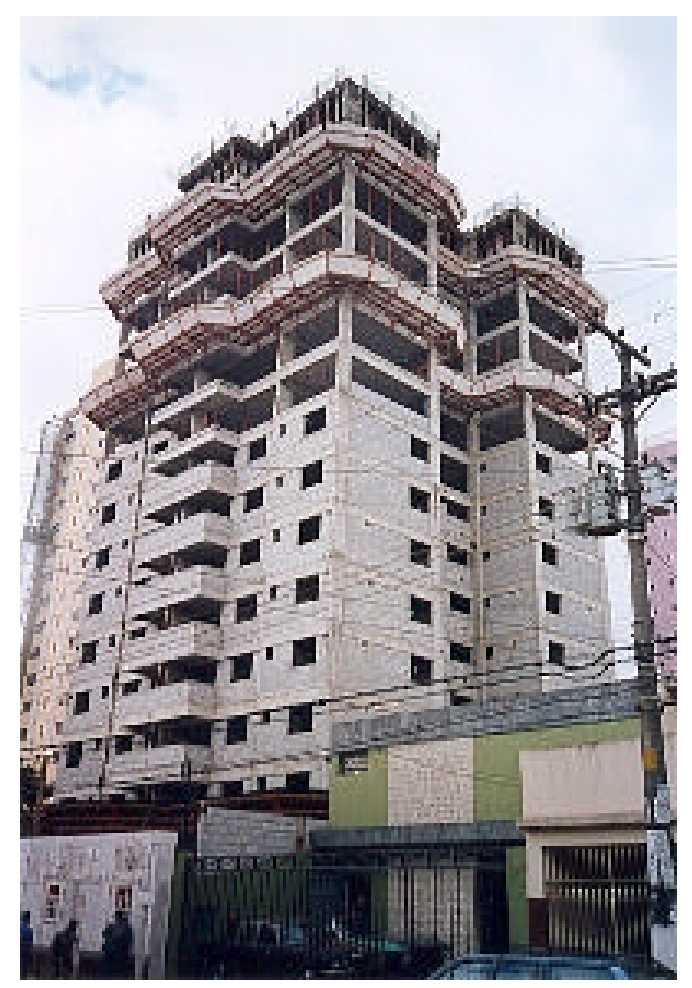

Figura 5.14 - Foto que ilustra o edifício protótipo PA.

- empreendimento PB: flat localizado no bairro da Bela Vista, região central da cidade de São Paulo, ilustrado na Figura 5.15 a seguir, com dezessete pavimentos-tipo; estrutura convencional de concreto armado e ciclo de produção de um pavimento-tipo por semana; vedações verticais internas em gesso 
acartonado e externas utilizando o SVM como método construtivo e aproximadamente $5.500 \mathrm{~m}^{2}$ de área de alvenaria;

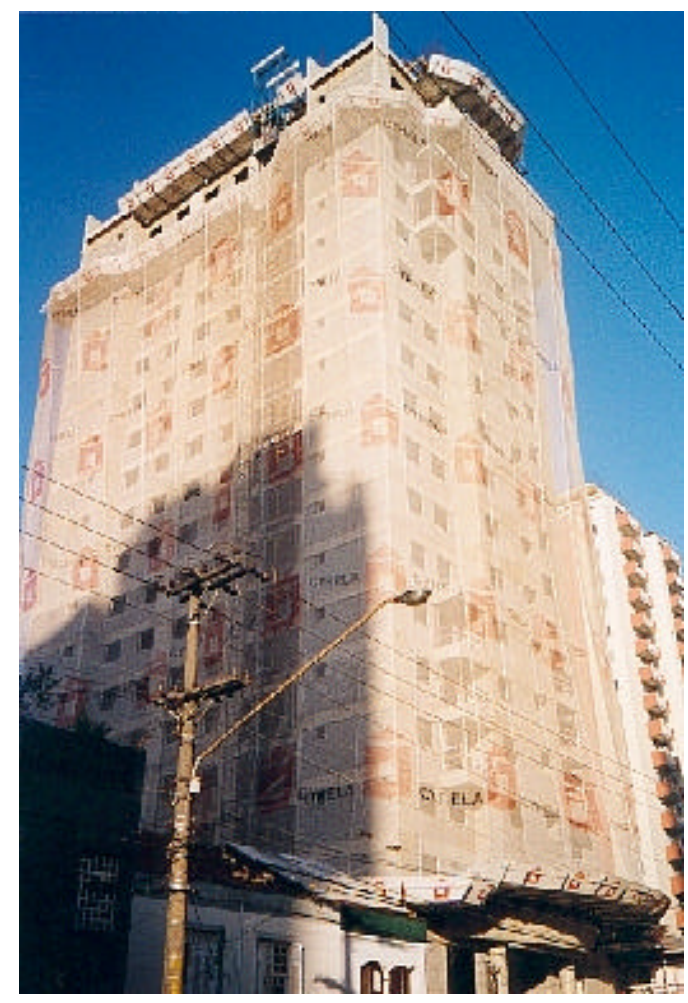

Figura 5.15 - Foto que ilustra o edifício protótipo PB.

- empreendimento PC: edifício residencial localizado no bairro da Bela Vista, região central da cidade de São Paulo, ilustrado na Figura 5.16 a seguir, com dezessete pavimentos, sendo quatro apartamentos por andar; estrutura convencional de concreto armado e ciclo de produção de um pavimento-tipo por semana; vedações verticais internas e externas utilizando o SVM como método construtivo e aproximadamente $10.500 \mathrm{~m}^{2}$ de área de alvenaria; mão-de-obra de produção própria da construtora; algumas particularidades deste empreendimento: contrapiso executado antes das alvenarias ${ }^{27}$ e utilização de batentes metálicos envolventes.

${ }^{27}$ Geralmente os contrapisos são executados depois das alvenarias. 


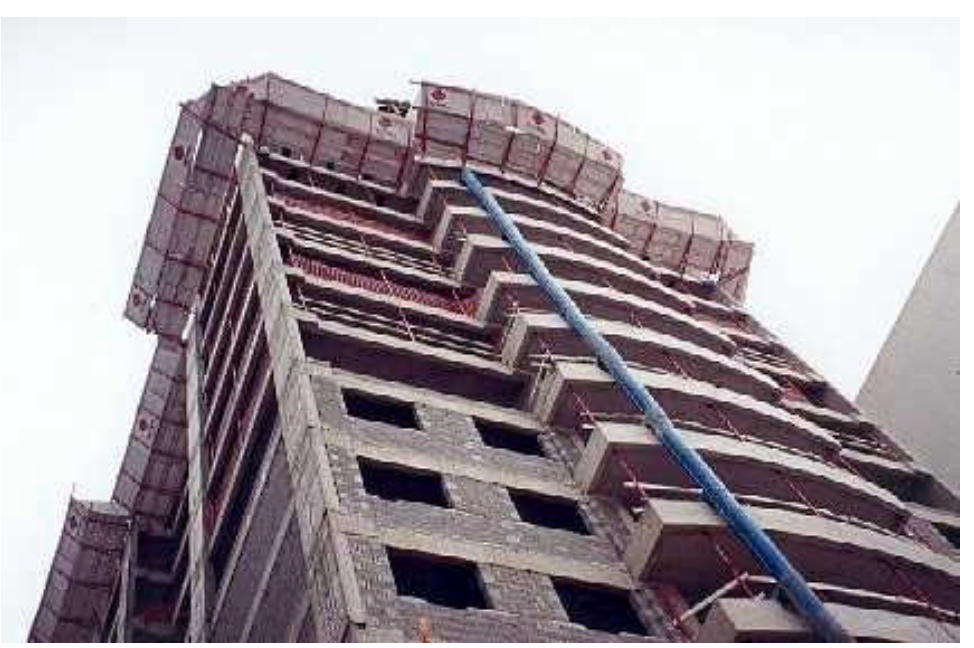

Figura 5.16 - Foto que ilustra o edifício protótipo PC.

Durante a construção das obras protótipos, a Glasser avaliou em campo todas as técnicas construtivas e a gestão do processo de produção definidas para o SVM.

\subsubsection{Etapa 9: Consolidação da tecnologia}

Essa etapa realimentou as etapas 3 e 4, além de realimentar a etapa anterior, conforme ilustrado na Figura 5.1. Vale destacar que quando esta etapa teve início ainda não havia sido concluído o terceiro empreendimento protótipo.

\subsubsection{Avaliação das implantações protótipo}

Os resultados das implantações protótipo podem ser analisados sob dois enfoques, um deles considerando os condicionantes de ordem técnica e comercial ligadas ao SVM e o outro considerando as relações com as empresas construtoras.

No enfoque técnico-comercial, a Glasser avaliou em condições reais, por exemplo, a produtividade alcançada pelas equipes de produção, os índices de consumo de argamassa de assentamento, os índices de perdas de materiais e componentes, aplicabilidade das planilhas de controle da execução bem como dos critérios para aceitação dos serviços.

Os resultados foram utilizados para refinar, por exemplo, as estimativas de consumo e perdas utilizadas nos orçamentos. Além disso, foram levantadas as informações necessárias para a consolidação dos manuais de projeto e execução. 
No enfoque das relações com as empresas construtoras, a Glasser avaliou as principais dificuldades enfrentadas, relacionadas às atividades de projeto, planejamento, execução e controle da execução. Embora os empreendimentos e as empresas construtoras apresentassem características diferenciadas, as dificuldades mostraram-se semelhantes, sendo as principais:

- projeto: indefinições de projeto gerando a falta de terminalidade nos serviços de alvenaria e perda de produtividade;

- planejamento: o não cumprimento dos prazos dos serviços com interfaces com a alvenaria gerando perda de produtividade;

- execução: as falhas de execução dos serviços com interfaces com a alvenaria comprometendo a qualidade dos serviços de alvenaria;

- controle da execução: interferências das equipes de controle das empresas construtoras durante a execução dos serviços, devido a incompatibilidades nos métodos utilizados e, em alguns casos, nos critérios para aceitação dos serviços.

A partir dessas observações, a Glasser estabeleceu algumas ações necessárias para que, em futuras obras, essas interferências fossem eliminadas ou ao menos minimizadas. De modo geral, a Glasser considerou necessária a aproximação com projetistas e coordenadores de projetos muito antes do início da execução, a fim de propor soluções e resolver possíveis interferências. Considerou também a aproximação com a equipe de engenharia das obras para analisar prazos e planos de execução, a fim de elaborar conjuntamente cronogramas adequados para a execução das alvenarias. Além disso, deveriam ser definidos conjuntamente os métodos de controle da execução.

\subsubsection{Consolidação dos manuais de projeto, execução e gestão}

A retroalimentação da implantação do SVM nas obras protótipos permitiu a atualização e consolidação dos manuais de projeto e execução. Esses manuais são constantemente atualizados e aperfeiçoados, incorporando novas soluções, novos materiais e componentes, fazendo-se, inclusive, detalhamentos adicionais. Além disso, algumas revisões do manual de execução buscam adaptá-lo aos procedimentos 
e documentação das empresas construtoras. O manual de gestão não foi concluído até o momento em que se concluiu o levantamento de dados para esta pesquisa.

Nesta etapa faziam parte duas outras sub-etapas relativas à difusão da tecnologia e às ações de normalização, certificação e credenciamento. Essas sub-etapas não foram iniciadas até o momento em que se concluiu o levantamento de dados para esta pesquisa.

\subsubsection{Etapa 10: Comercialização em escala de mercado}

Esta etapa realimentou a etapa anterior, conforme ilustrado na Figura 5.1, principalmente com o objetivo de aperfeiçoamento do SVM. Vale destacar que uma das sub-etapas refere-se à construção de edifícios em escala piloto.

Esta etapa trata principalmente da preparação e organização da nova estrutura comercial da Glasser, necessária à comercialização do SVM. Após a construção dos três edifícios protótipos, a Glasser iniciou a comercialização do SVM em escala piloto, totalizando vinte empreendimentos executados entre o primeiro semestre de 2000 e o segundo semestre de 2002. Então, iniciourse a comercialização em escala de mercado que, até o mês de abril de 2003, totalizavam dezesseis empreendimentos. $\mathrm{Na}$ Tabela 5.2 a seguir, apresenta-se a relação das empresas construtoras parcerias da Glasser nesta etapa e a quantidade de empreendimentos onde utilizaram o SVM, nas escalas piloto e de mercado. 
Tabela 5.2 - Relação das empresas construtoras parcerias da Glasser e a quantidade de empreendimentos onde utilizaram o SVM, nas escalas piloto e de mercado.

\begin{tabular}{|c|c|c|c|}
\hline Empresa construtora & Escala piloto & $\begin{array}{c}\text { Escala de mercado } \\
\text { (até abr/03) }\end{array}$ & $\begin{array}{c}\text { Total de } \\
\text { empreendimentos }\end{array}$ \\
\hline A (*) & 8 & 4 & $12+1=13$ \\
\hline B (*) & 3 & 3 & $6+1=7$ \\
\hline C $(*)$ & - & - & 1 \\
\hline D & 3 & 1 & 4 \\
\hline E & 1 & - & 1 \\
\hline F & 1 & - & 5 \\
\hline G & - & 5 & $\mathbf{3 9}$ \\
\hline H & $\mathbf{2 0}$ & $\mathbf{1 6}$ & 4 \\
\hline \multicolumn{2}{|c|}{ TOTAL } & $(*)$ empresas que utilizaram o SVM na construção de protótipos. & 1 \\
\hline
\end{tabular}

As principais características dessas empresas construtoras são apresentadas a seguir:

- construtora A: trata-se de uma empresa de grande destaque no cenário da indústria imobiliária paulista. É o principal cliente da Glasser, além de importante colaborador no processo de desenvolvimento do SVM. Como características particulares possui um departamento específico que desenvolve os projetos de alvenaria e um departamento de qualidade bastante atuante durante todo o processo de produção.

- construtora B: como característica particular essa empresa, por dispor de mão-deobra própria para a execução dos serviços de alvenaria, optou por adquirir apenas o kit com os materiais e componentes que compõem o SVM, além da assessoria técnica da Glasser durante o desenvolvimento das atividades de projeto e execução;

- construtoras $\mathrm{C}$ e $\mathrm{G}$ : desenvolveram apenas um empreendimento cada em parceria com a Glasser, sendo que não houve continuidade m utilização do SVM para as vedações verticais das suas novas obras;

- construtora D: assim como a empresa A, ocupa lugar de destaque no cenário da indústria imobiliária paulista. Além disso, destaca-se pela busca e utilização de 
novas tecnologias construtivas com foco no aumento da produtividade e industrialização do processo de produção;

- construtora E: trata-se de uma pequena empresa de construção que vem investindo na melhoria da qualidade de suas obras e que vem buscando a participação de fornecedores especializados;

- construtora F: trata-se de um pequeno incorporador, cujo empreendimento desenvolvido em parceria com o fornecedor, por diversos motivos que serão apresentados adiante, representou um importante aprendizado para o fornecedor, sobretudo com relação à análise dos riscos envolvidos na comercialização e à influência do aplicador no desempenho da Glasser;

- construtora $\mathrm{H}$ : trata-se de uma empresa que vem investindo crescentemente no setor, destacando-se pelo alto padrão arquitetônico e a excelência de qualidade nos acabamentos dos seus empreendimentos.

A seguir são apresentadas as sub-etapas que integram esta etapa.

\subsubsection{Definição da estratégia comercial}

A Glasser, em função dos recursos disponíveis, optou por desenvolver a estratégia comercial internamente, ao invés de contratar uma empresa de marketing e, como primeira ação, avaliou a necessidade de segmentação do mercado, a fim de identificar os potenciais compradores. Com a premissa de atuar em um mercado onde seria competitiva, a Glasser definiu as seguintes características relacionadas às empresas construtoras e ao tipo de empreendimento apropriados aos objetivos do SVM:

- empresas construtoras que estão buscando a racionalização do processo de construção através da utilização de blocos cerâmicos de qualidade e projetos de alvenaria;

- edifícios com estrutura de concreto armado, com dez ou mais pavimentos.

Para cada cliente potencial deveriam ser identificados os contatos, ou seja, as pessoas que cotam, compram, decidem, influenciam, especificam e negociam. 


\subsubsection{Estruturação do sistema de comercialização}

A idéia fundamental e nova para o departamento comercial da Glasser é a de que o SVM trata da venda de serviço e que, desta forma, a ênfase na comercialização são os serviços agregados.

Nesta nova estrutura de comercialização, a Glasser avaliou a necessidade de efetuar a apropriação mais detalhada de custos de serviços integrados pelo SVM, para levantar dados e definir os parâmetros e os argumentos necessários nas negociações com os clientes potenciais.

A Glasser também avaliou a necessidade de maior sinergia interna entre o pessoal da área comercial e avaliou, inclusive, a criação de um novo cargo de gerência para a coordenação da implantação da nova estrutura comercial voltada para a comercialização de sistemas de produção. Essa função foi, no entanto, assumida pelo diretor comercial da empresa.

\subsubsection{Redação de contratos de comercialização}

A Glasser elaborou os principais modelos de contratos de comercialização contando com a experiência de seus profissionais e de seu consultor de tecnologia, quanto à conhecimentos de administração de obras, do método construtivo de alvenaria racionalizada, dos problemas patológicos mais comuns nas alvenarias, das possíveis reclamações dos futuros proprietários e do conteúdo dos contratos de subempreitada.

A Glasser definiu, então, os itens fundamentais para compor os contratos para a comercialização do SVM:

- o preço do $\mathrm{m}^{2}$ da parede pronta e, a partir da área total estimada através dos projetos, o preço global;

- as regras $^{28}$ utilizadas no levantamento das áreas de alvenaria objeto do contrato e que deverão ser aplicadas nas medições dos serviços executados;

\footnotetext{
${ }^{28}$ Em geral as empresas construtoras utilizam em seus levantamentos as áreas de material e de mãode-obra. A área de material é geralmente utilizada para estimar as quantidades de insumos e considera a área líquida das paredes, descontando-se todos os vãos. A área de mão-de-obra, geralmente utilizada para remunerar a mão-de-obra, é sempre maior ou igual à área de material pois no seu cálculo
} 
- a identificação das empresas parceiras da Glasser que fornecerão os demais materiais e componentes que integram o SVM;

- as condições de pagamento, ou seja, o estabelecimento das datas nas quais serão efetuadas as medições dos serviços e o faturamento dos materiais e componentes fornecidos;

- o reajuste de preços, ou seja, o estabelecimento dos índices que serão utilizados para corrigir os preços contratados e a data a partir da qual os preços serão reajustados;

- o escopo dos serviços;

- as responsabilidades da Glasser e das empresas construtoras;

- os prazos para a execução dos serviços;

- o termo de garantia, ou seja, o compromisso da Glasser em assumir a responsabilidade pelo desempenho adequado das alvenarias e correção de eventuais problemas patológicos com origem nas alvenarias.

\subsubsection{Identificação e treinamento de aplicadores credenciados}

A Glasser verificou o cadastro que possui em seu banco de dados de aplicadores credenciados e avaliou a quantidade de empresas disponíveis, bem como os resultados obtidos em serviços prestados a terceiros e o número de obras simultâneas que essas empresas teriam capacidade de gerir.

Uma das obras protótipo foi executada por uma empresa cadastrada pela Glasser; no entanto, as empresas construtoras parceiras da Glasser também colaboraram na identificação de aplicadores e, em alguns casos, influenciaram a decisão da Glasser quanto ao credenciamento dessas empresas. Até a finalização da coleta de dados para este trabalho, seis empresas fornecedoras de serviços de execução estavam qualificadas pela Glasser para a execução do SVM, sendo três delas indicadas por empresas construtoras parceiras.

aplicam-se regras empíricas para recompensar o trabalho, por exemplo, de requadração de vãos. Essas regras são estabelecidas em comum acordo e, no caso do SVM, a Glasser utiliza as regras definidas nas Tabelas de Composições de Preços para Orçamento (TCPO 2000, 1999). 
Inicialmente o instrutor da Glasser responsável pelo treinamento expõe os objetivos do treinamento e, a seguir, apresenta os procedimentos de execução em suas diferentes etapas e atividades, denominados de módulos. Os módulos são a marcação da primeira fiada, a elevação das demais fiadas, a fixação da alvenaria à estrutura, a fixação das telas metálicas, a aplicação do chapisco rolado e o preparo de argamassa de assentamento. Então, são apresentados os itens do controle do processo e as tolerâncias na aceitação dos serviços.

Os participantes são informados das ações corretivas e das conseqüências nos casos de não cumprimento dos procedimentos relativos ao treinamento. Tais conseqüências podem variar desde uma advertência e solicitação de correção dos serviços executados até o afastamento do funcionário.

O início de novos funcionários fica condicionado à participação no módulo de treinamento correspondente à função que irão exercer na obra.

\subsubsection{Promoção e propaganda}

Os sistemas de comunicação dirigidos aos clientes potenciais utilizados pela Glasser para a divulgação do SVM foram:

- marketing pessoal;

- reportagens técnicas em revistas e jornais de grande circulação no setor;

- site da empresa na internet, através da disponibilização das diretrizes básicas de projetos, vantagens potenciais oferecidas e fotos de obras.

\subsubsection{Comercialização em escala piloto}

Nesta sub-etapa a Glasser comercializou o SVM em vinte empreendimentos, para seis empresas construtoras parceiras, conforme a Tabela 5.2.

A construção dos três edifícios protótipos foram fundamentais e alimentou indiretamente esta etapa, tendo sido uma importante fonte de aprendizados técnico e comercial. No entanto, as relações com as empresas construtoras e as dificuldades apontadas no item 5.3.9.1 pouco se alteraram. A seguir estão relacionadas as principais dificuldades enfrentadas: 
- embora as empresas construtoras elaborem com antecedência seus projetos considerando a utilização do SVM, a Glasser geralmente não inicia os serviços de execução nos prazos previstos pois os contratos geralmente não são efetivados com a antecedência necessária. Assim, os serviços de execução das alvenarias geralmente são iniciados com atraso, implicando na necessidade de aumento das equipes de produção e de controle da execução. O aumento das equipes de produção tem diversas implicações tais como a necessidade de ampliar também as equipes de controle, as áreas de estocagem de insumos e os tempos de utilização dos equipamentos de transporte vertical dos insumos. Ou seja, os atrasos iniciais geralmente criam condições adversas que interferem principalmente no gerenciamento do processo de produção incluindo o controle da execução e logística de insumos na obra;

- o atraso na contratação dos serviços com interface com a alvenaria como, por exemplo, a execução das instalações também implica em perda de produtividade nos serviços de alvenaria devido às interferências geradas, uma vez que o início das alvenarias depende da liberação, por exemplo, dos eletrodutos flexíveis. Além disso, vale destacar a dificuldade no planejamento dos serviços de alvenaria devido ao planejamento deficiente de outros serviços com interface com a alvenaria, sob a responsabilidade da empresa construtora;

- dificuldade no transporte vertical de insumos, pois as empresas construtoras geralmente disponibilizam seus equipamentos de transporte vertical conforme as disponibilidades da obra e não conforme as necessidades da Glasser, previamente estabelecidas;

- dificuldade no controle de estoque, sobretudo quando outras empresas utilizam materiais semelhantes ou iguais aos utilizados pela Glasser tal como as argamassa utilizadas no assentamento;

- em edifícios residenciais, a comercialização de apartamentos com a possibilidade de modificações do leiaute das paredes geralmente implica em interferências nos serviços de alvenaria, ou por falta de terminalidade ou por necessidade de serviços de demolição e re-execução. Além disso, as empresas construtoras não 
disponibilizam os projetos de produção para as vedações desses apartamentos, apenas as plantas de arquitetura com a disposição das paredes;

- projetos incompletos e a necessidade de se tomar decisões na obra ou interromper os serviços até que o projeto seja concluído;

- necessidade de equipes, ferramentas e equipamentos adicionais para antecipar a execução de alvenarias externas por condicionantes de segurança e principalmente por número insuficiente de bandejas de proteção, conforme a Norma Regulamentadora - NR18 - Condições e Meio Ambiente de Trabalho na Indústria da Construção (MINISTÉRIO DO TRABALHO, 1995).

Nesta etapa de comercialização em escala de mercado, vale destacar que a Glasser optou por desenvolver uma equipe própria de produção de alvenaria, utilizando sua estrutura interna no processo de recrutamento, seleção dos candidatos, avaliação dos selecionados, escolha e contratação. Os funcionários contratados, entre eles encarregados, pedreiros e serventes, foram treinados no próprio canteiro de obras, especificamente no canteiro de uma das obras da construtora A.

Nesta sub-etapa, a Glasser também intensificou seus esforços na busca de uma nova argamassa de assentamento que atendasse às exigências específicas do SVM, identificadas pela pesquisa desenvolvida através do convênio de desenvolvimento tecnológico EPUSP/Glasser-01 (2000) e também através de seu consultor.

Na construção em escala piloto, vale destacar o edifício executado em parceria com a empresa F, por dois motivos. O primeiro deles refere-se aos estudos de viabilidade, sendo que a Glasser decidiu-se pela comercialização mesmo tendo avaliado que os riscos em função principalmente do grau de deformabilidade da estrutura, conforme item 5.3.3.3, poderiam ser altos. Os cuidados necessários foram tomados já na fase de projeto, considerando-se a necessidade de reforços nas interfaces com a estrutura através da utilização de telas metálicas. Mesmo assim, durante a execução dos serviços foram identificados alguns problemas nessas interfaces e a Glasser responsabilizoutse pela sua correção. O segundo motivo refere-se à enorme dificuldade na gestão e organização da mão-de-obra de produção das alvenarias, fornecida por um aplicador credenciado pela Glasser que já havia executado serviços anteriormente com resultados satisfatórios nas empresas A e D. Por razões diversas e 
internas a essa empresa, os operários foram constantemente substituídos durante o período de execução dos serviços, implicando na necessidade de treinamentos contínuos e exigindo a intensificação do acompanhamento e controle da execução dos serviços. Além disso, essa dificuldade comprometeu o atendimento dos prazos e, em alguns momentos, a qualidade esperada.

Os resultados insatisfatórios nessa obra reforçaram a importância da análise prévia do comportamento estrutural do edifício e da avaliação dos riscos envolvidos na comercialização do SVM. Além disso, ressaltaram a influência do aplicador nos resultados da comercialização e a importância do constante monitoramento do desempenho dessas empresas. Vale destacar também que a Glasser elaborou e redigiu um roteiro para a correção de fissuras em revestimentos de pequena espessura, sendo que esse roteiro foi utilizado para a recuperação das fissuras nessa obra. Elaborou e redigiu ainda um roteiro para a execução de reforços em revestimentos e passou a recomendá-lo às empresas construtoras.

Após a comercialização da vigésima obra em escala piloto a Glasser iniciou a comercialização em escala de mercado, conforme a sub-etapa tratada a seguir.

\subsubsection{Comercialização em escala de mercado}

Nesta sub-etapa, a Glasser comercializou o SVM em dezesseis empreendimentos, até abril de 2003, para cinco empresas construtoras parceiras, conforme apresentado na Tabela 5.2.

A comercialização em escala de mercado confundiu-se com a em escala piloto, uma vez que a Glasser não alterou os seus procedimentos técnicos e comerciais a partir dos resultados da implantação em escala piloto.

Nessa etapa vale ressaltar que as principais empresas construtoras parceiras da Glasser, com edifícios executados em escala piloto, continuaram utilizando o SVM em seus empreendimentos. Além disso, a Glasser estabeleceu uma no va parceria com a empresa H e o SVM estava sendo aplicado em cinco empreendimentos dessa empresa. 


\subsection{Análise dos resultados}

A Glasser, através da comercialização do SVM, vem alcançado os seus objetivos de ampliação de mercado e aumento da rentabilidade dos ne gócios. $\mathrm{O}$ autor não teve acesso a números para analisar os resultados financeiros alcançados pela Glasser; no entanto, seguem algumas considerações.

Quanto à ampliação de mercado destacam-se principalmente as parcerias com as empresas construtoras A e D, pois são de grande relevância na indústria imobiliária da cidade de São Paulo e que, antes do SVM, não tinham a Glasser como principal fornecedor de componentes de alvenaria, pelo contrário, utilizavam sobretudo alvenaria de bloco cerâmico.

Quanto ao aumento da rentabilidade dos negócios da Glasser, destaca-se que a comercialização do SVM vem sendo realizada dentro da faixa de preços definida pela empresa e, além disso, as metas quanto ao número de obras comercializadas estão sendo também alcançadas.

A análise dos resultados nas empresas construtoras não faz parte do escopo deste trabalho; no entanto, vale observar que a maioria delas tem dado continuidade na utilização do SVM em seus empreendimentos. Somente nas empresas C, G e F não houve continuidade na utilização do SVM e, segundo a visão da Glasser, a não continuidade do fornecimento do SVM em outros empreendimentos dessas empresas está relacionada a condicionantes de ordem comercial, sendo que a decisão dos diretores dessas empresas foi influenciada pela análise do custo de $\mathrm{m}^{2}$ de construção da alvenaria e não do $\mathrm{m}^{2}$ de construção do edifício, conforme o item 5.3.1.2. Na empresa F, os resultados insatisfatórios apontados na sub-etapa 5.3.10.6, de comercialização em escala piloto, podem também ter influenciado a sua decisão.

A análise do processo de desenvolvimento do SVM à luz da fundamentação teórica desenvolvida nos capítulos 2, 3 e 4 será apresentada a seguir, no sexto capítulo. 


\section{CONSIDERAÇÕES FINAIS}

Neste último capítulo analisa-se o processo de desenvolvimento do SVM à luz da conceituação teórica apresentada nos capítulos 2, 3 e 4, apresentando-se uma proposta de condução do processo de desenvolvimento de uma inovação a fim de orientar outros fornecedores de materiais e componentes dispostos a utilizar a inovação como vantagem competitiva. Finalmente, analisam-se as limitações do trabalho, propondo-se alguns temas para trabalhos futuros.

\subsection{Análise dos condicionantes setoriais}

Os principais objetivos da Glasser ao iniciar o processo de desenvolvimento do SVM eram: (a) ampliar o mercado de atuação, diante de um mercado cada vez mais competitivo e (b) aumentar a rentabilidade dos negócios da empresa, devido à redução das margens de lucro em função dos constantes aumentos de preços do cimento - principal matéria prima para fabricação dos blocos de concreto - e o pequeno poder de negociação das empresas fabricantes de blocos de concreto com as indústrias de cimento.

O primeiro objetivo implicava que o SVM representasse um avanço quanto ao método racionalizado de produção de alvenarias, considerando-se principalmente seu desempenho superior frente às vedações executadas com blocos cerâmicos de qualidade. O segundo objetivo implicava na necessidade de agregar valor aos componentes de alvenaria, devendo-se integrá-los numa solução completa que contivesse, inclusive, os serviços de execução.

No entanto, algumas características estruturais do setor da construção, apresentadas no item 2.3, funcionaram como barreiras à comercialização do SVM, sendo as principais:

- a falta de visão sistêmica dos profissionais das empresas construtoras em geral interfere na capacidade de avaliação das vantagens potenciais do SVM;

- o menor preço como principal critério utilizado pelas empresas construtoras na seleção de fornecedores e a análise comparativa efetuada sobre o custo do $\mathrm{m}^{2} \mathrm{de}$ 
construção da alvenaria e não do custo do $\mathrm{m}^{2}$ do edifício não é adequada para a avaliar a relação custo/benefício do SVM;

- a postura conservadora de grande parcela das empresas construtoras e incorporadores e a aversão a quaisquer inovações;

- as relações convencionais entre as empresas construtoras e seus fornecedores geralmente não são adequadas à implantação do SVM;

- a estrutura e organização para a produção das empresas construtoras em geral são inadequadas à implantação do SVM.

Os fornecedores de materiais e componentes interessados devem reconhecer essas características do setor antes de se lançarem no desenvolvimento de uma inovação.

\subsection{Proposta para condução do processo de desenvolvimento}

Frente a tudo o que foi anteriormente apresentado e discutido, acredita-se que a síntese das idéias aqui colocada possa auxiliar muitas outras empresas fornecedoras a trilharem o caminho empreendido pela empresa objeto do caso prático. Assim, neste item apresenta-se uma proposta para a condução do processo de desenvolvimento de uma inovação baseada na análise do modelo e do processo de desenvolvimento do SVM utilizado pela Glasser e do modelo de desenvolvimento de MPSConst. apresentado no item 3.1.

Etapa 01 - Estudos iniciais: conforme apresentado no item 3.1, sub-item 'estudos iniciais', esta etapa tem uma importância vital e explora a viabilidade em satisfazer uma necessidade do mercado. No caso do SVM, a Glasser induziu uma necessidade, na medida em que desenvolveu a inovação sem que fosse solicitada pelo mercado. A indução de uma necessidade requer do fornecedor uma postura pró-ativa, que é um dos seus novos papéis analisados no item 3.3. A forma de comercialização inovadora do SVM, como sistema de produção, necessitava de comprovação e, desta forma, vale ressaltar que a participação de um consultor especializado, principalmente por sua experiência e atuação no mercado, foi fundamental para influenciar a decisão da Glasser pelo desenvolvimento do SVM e também nas decisões tomadas nas demais etapas do processo de desenvolvimento. A presença de um líder ou de um profissional experiente e com capacidade técnica é fundamental para a criação de um 
ambiente favorável à inovação dentro da empresa fornecedora. Nenhuma empresa fornecedora de materiais e componentes que queira se lançar ao desafio de oferecer ao mercado o seu produto aplicado ao processo produtivo de uma empresa construtora poderá fazê-lo sem passar por esta fase de estudos iniciais em que "uma boa idéia" deverá passar pelo crivo técnico, econômico e financeiro para que não se coloque a perder os parcos recursos de que as empresas nacionais dispõem para pesquisa e desenvolvimento tecnológico;

Etapa 02 - Concepção: nesta etapa, conforme o item 3.1, sub-item 'concepção do MPSConst.', as ações da Glasser concentraram-se em fixar as características da nova família de componentes modulares de alvenaria utilizando-se o módulo básico 3M, fixar as principais diretrizes de projeto considerando-se essa nova família e também definir os parâmetros para otimizar o desempenho das alvenarias. No entanto, além dessas características, vale ressaltar a importante estratégia da Glasser que, detentora do domínio técnico apenas da produção dos componentes de alvenaria, viabilizou o SVM através do desenvolvimento integrado com empresas parcerias para o fornecimento dos demais componentes e materiais. Além disso, definiu que os projetos de alvenaria e também os serviços de aplicação seriam executados por empresas parceiras. A formação de parcerias pode constituir uma importante estratégia para viabilizar o desenvolvimento de uma inovação. Além disso, a novidade introduzida no componente principal do sistema também pode contribuir para que o mercado realmente enxergue o produto como algo novo que precisa ser devidamente introduzido no sistema de produção da empresa e não como algo de domínio comum;

Etapa 03 - Método de projeto: os projetos de alvenaria do SVM integram não somente a modulação mas também a compatibilização com os demais subsistemas do edifício e também as características relacionadas à produção. O projeto para a produção de uma inovação é uma ferramenta fundamental no processo de desenvolvimento, pois todos os princípios da tecnologia são definidos nos projetos. Para conduzir o desenvolvimento das atividades de projeto é necessário que o fornecedor da inovação atue com visão sistêmica, dominando o processo de produção da inovação em si e também compreendendo o processo de produção do edifício como um todo. Nesta etapa a Glasser definiu os componentes e as diversas 
soluções dos projetos de alvenaria do SVM. Definiu também especificações para parametrização das estruturas. Vale ressaltar a importância dessas especificações tanto para o desenvolvimento das atividades de projeto como para avaliar os riscos de comercialização, uma vez que os problemas patológicos mais comuns nas alvenarias ocorrem na interface com a estrutura de concreto armado do edifício. Finalmente redigiu um manual contendo as diretrizes para orientar a elaboração dos projetos de alvenaria do SVM, utilizado pela Glasser na qualificação dos projetistas parceiros. Além disso, a criação e consolidação de uma linguagem projetual específica, sub-etapa não concluída pela Glasser, constitui uma importante ferramenta para facilitar a interpretação dos projetos principalmente pelas equipes de produção. Os investimentos em métodos de projetos específicos para solucionar cada um dos subsistemas do edifício continuam sendo prementes e os fornecedores de materiais e componentes poderão contribuir muito para a evolução tecnológica na medida em que desenvolverem tais métodos, ainda que afeitos somente aos seus produtos;

Etapa 04 - Produção de componentes: esta etapa foi desenvolvida conforme os objetivos estabelecidos no item 3.1, sub-itens 'projeto de componentes e elementos' e 'produção experimental de componentes e elementos'. No entanto, conforme a estratégia da Glasser de desenvolvimento integrado com outros fornecedores, além da definição das características funcionais, formais e materiais e os projetos para produção e avaliação experimental dos componentes e elementos, nesta etapa vale destacar a colaboração dos fabricantes parceiros no desenvolvimento principalmente dos elementos pré-fabricados e das argamassas de assentamento, conforme o tem 5.3.4.3. O edifício, por ser um organismo complexo, exige, para a sua completa produção, a interação de um sem número de agentes os quais, acredita-se, deverão trabalhar em estrita parceria a fim de que todos os subsistemas possam trabalhar harmonicamente e, por conseqüência, também o edifício;

Etapa 05 - Método construtivo: esta etapa foi desenvolvida conforme os objetivos estabelecidos no item 3.1, sub-item 'projeto de produção do edifício (ou de suas partes)'. E, em função da estratégia da Glasser em utilizar aplicadores credenciados para execução dos serviços, nesta etapa foi redigido o manual contendo os procedimentos de execução do SVM, ferramenta básica para o treinamento e 
qualificação desses aplicadores. Nesta etapa é importante considerar a necessidade de criação de ferramentas e equipamentos voltados à racionalização do processo de produção. Além disso, é fundamental que as técnicas construtivas definidas sejam previamente experimentadas e avaliadas. Se o fornecedor de materiais e componentes ão conseguir demonstrar que o seu produto tem grande potencial de levar à maior produtividade da mão-de-obra, a menores desperdícios e melhor desempenho do edifício, certamente, ele sempre enxergará o mercado como "reativo" a todas as novidades; afinal, paira no ar o velho ditado "em time que está ganhando não se deve mexer". Portanto, deve fazer parte da metodologia de desenvolvimento a experimentação das técnicas e métodos construtivos, visando o aumento da produtividade e a melhoria qualidade;

Etapa 06 - Método de gestão: esta etapa não é explícita no modelo proposto por Sabbatini (1989); no entanto, assume importância fundamental na comercialização do SVM como sistema de produção. A Glasser, assumindo as responsabilidades pelo desempenho do SVM por custos e prazos, passou a atuar também na implantação do SVM nos canteiros de obras das empresas construtoras e, para isto, definiu um método para a gestão da inovação, integrando as atividades de planejamento, gerenciamento e controle da produção. Nesta etapa, algumas sub-etapas não foram concluídas pela Glasser e as consequiências vêm sendo identificadas na implantação do SVM nas obras onde tem sido comercializado, quando se observam as dificuldades no planejamento dos serviços junto às empresas construtoras, na organização dos dados necessários à análise dos resultados financeiros e também na organização dos dados necessários ao controle do processo de produção. Portanto, empreender ações para que se tenha uma forte gestão do processo de implantação será imprescindível para o sucesso de qualquer desenvolvimento de uma inovação tecnológica sob pena de, em não existindo, o processo ficar fadado ao insucesso e conseqüente perda dos recursos investidos;

Etapa 07 - Avaliação experimental: esta etapa também não é explícita no modelo proposto por Sabbatini (1989) e, no processo de desenvolvimento de uma inovação, assume importância fundamental, considerando-se a necessidade de avaliar o desempenho dos elementos e componentes que integram a inovação e ainda para realimentar o processo de desenvolvimento desses elementos e componentes. Além 
disso, nesta etapa é importante que a inovação seja submetida à avaliação de desempenho por institutos ou centros de pesquisa que sejam especializados na avaliação de inovações e que possuam credibilidade no setor. No entanto, no desenvolvimento do SVM, esta etapa foi realizada parcialmente e pouco contribuiu no processo de desenvolvimento da inovação. O convênio estabelecido com a Escola Politécnica da Universidade de São Paulo foi interrompido e os convênios previstos com o Instituto de Pesquisas Tecnológicas de São Paulo e com a Associação Brasileira de Cimento Portland não foram efetivados. Apesar desta etapa ter uma importância secundária no desenvolvimento do SVM, somente tendo alimentando a etapa 8 , relativa à construção de edifícios protótipos, é certo que ela deverá ser melhor conduzida pelas empresas fornecedoras que se proponham a desenvolver uma inovação, sobretudo no caso daqueles produtos em que não se tenha um histórico de sua utilização no País, o que não era o caso do objeto do caso prático;

Etapa 08 - Construção de protótipos: esta etapa foi desenvolvida conforme os objetivos estabelecidos no item 3.1, sub-item 'projeto e construção de protótipos'. Nesta etapa, além da avaliação dos condicionantes de ordem técnica, a Glasser avaliou os condicionantes de ordem comercial, por exemplo, os índices reais de perda e consumo de insumos. Vale ressaltar que o edifício protótipo tem um objetivo muito bem definido no processo de desenvolvimento de uma inovação e, durante sua construção, as incertezas das etapas anteriores devem ser equacionadas e o fornecedor da inovação deve buscar os dados e informações a fim de consolidar os documentos e os manuais desenvolvidos. Nesse contexto, esta se torna uma etapa imprescindível sendo que a escolha do(s) edifício(s) protótipo(s) é fundamental pois é necessário que tanto o ambiente seja favorável para que as atividades sejam completamente executadas, assim como os prazos de execução do edifício deverão ser adequados ao tempo demandado pelas atividades de implantação da inovação;

Etapa 09 - Consolidação da tecnologia: esta etapa foi desenvolvida conforme os objetivos estabelecidos no item 3.1, sub-itens 'avaliação dos protótipos e do MPSConst.', 'divulgação' e 'consolidação da tecnologia'. Nesta etapa, foram consolidados os manuais de projeto e execução e, além disso, foram ajustados os referenciais, por exemplo, relacionados ao consumo e perdas. As sub-etapas relativas à difusão da tecnologia e às ações de normalização e credenciamento que não foram 
empreendidas pela Glasser são importantes para a consolidação da tecnologia, sob pena de todo o conhecimento acumulado acabar se perdendo pela ausência de uma documentação adequada à consolidação da tecnologia;

Etapa 10 - Comercialização em escala de mercado: esta etapa foi desenvolvida conforme os objetivos estabelecidos no item 3.1, sub-itens 'construção em escala piloto', 'aperfeiçoamento da tecnologia' e 'construção em escala de mercado'. A Glasser, antes da comercialização em escala de mercado, definiu uma sub-etapa intermediária de comercialização em escala piloto. Essa sub-etapa teve importância fundamental para avaliar principalmente a capacidade de seus aplicadores credenciados em gerir mais de uma obra simultaneamente. Nesta etapa ficou evidente a dificuldade das empresas construtoras na condução do processo de implantação de inovações. Assim, as empresas fornecedoras que se proponham a desenvolver uma inovação devem compreender essa dificuldade e empreender ações para minimizar os impactos negativos, o que somente será possível se passar por esta etapa da metodologia de desenvolvimento.

\subsection{Sugestões para o desenvolvimento de trabalhos futuros}

O trabalho considerou o processo de inovação na construção de edifícios analisandose a visão dos fornecedores de materiais e componentes, destacando-se as tendências atuais e os novos papéis que devem desempenhar para que utilizem a inovação como uma vantagem competitiva. No entanto, diversos agentes participam do processo de desenvolvimento de uma inovação e a visão desses agentes pode colaborar para uma análise mais abrangente desse processo. Nesse sentido, para o desenvolvimento de trabalhos futuros sugere-se, por exemplo, a análise da colaboração potencial de projetistas como verdadeiros agentes da inovação.

Este trabalho considerou sobretudo as inovações classificadas por Amorim (1999) como sendo inovações de produto para a construção, conforme o item 2.1. As inovações organizacionais também podem constituir-se em estratégia competitiva para os fornecedores de materiais e componentes. As inovações de produto de construção também não foram consideradas neste trabalho, na visão dos fornecedores. Assim, tem-se duas questões que poderiam ser analisadas em trabalhos futuros. 
Finalmente, sugere-se que o modelo utilizado pela Glasser para o desenvolvimento do SVM seja aplicado por outras empresas interessadas na comercialização de sistemas de produção. Alguns fornecedores de materiais e componentes estão se preparando para isso, por exemplo, a empresa Portobello S.A. que vem desenvolvendo e comercializando um sistema de produção de revestimentos cerâmicos.

\subsection{Considerações finais}

Uma nova tendência do setor da construção na qual as empresas construtoras têm buscado soluções construtivas completas deve alterar as relações convencionalmente estabelecidas entre essas empresas e os fornecedores de materiais e componentes. As empresas construtoras estão interessadas em ampliar o papel de seus fornecedores, do simples fornecimento de componentes, para dividir ou assumir maior responsabilidade em outras atividades envolvidas na construção de edifícios. Desta forma, os fornecedores devem se preparar para atender essa necessidade e, além disso, devem atuar com postura pró-ativa a fim de ocupar uma posição de destaque frente a seus concorrentes.

A aproximação inevitável e necessária entre os fornecedores de materiais e componentes e as empresas construtoras exige a alteração nas relações convencionalmente estabelecidas entre ambas. Neste trabalho analisou-se a formação de parcerias como um tipo de relacionamento mais adequado; no entanto, o estabelecimento de um compromisso de colaboração e confiança pode demandar um período de conhecimento mútuo. O conceito de parceria pode ser adotado progressivamente através de colaborações informais que evoluem para relações de parceria com estrutura formal.

No caso prático, evidencioutse a dificuldade das empresas construtoras na condução do processo de implantação de uma inovação no seu processo produtivo, interferido negativamente nas atividades desenvolvidas pelo fornecedor da inovação. Assim, acredita-se que as empresas construtoras também têm um papel fundamental a cumprir, atuando como integradora de sistemas, para que as vantagens competitivas da utilização de uma inovação sejam plenamente alcançadas. 


\section{LISTA DE REFERÊNCIAS}

ABBATE, V. Ligação das paredes com pilares precisa de reforço. Revista Téchne, São Paulo, n.71, 2003.

AMORIM, S. L. Inovações tecnológicas nas edificações: papéis diferenciados para construtores e fornecedores. Artigo técnico. Niterói, 1999.

ASSOCIAÇÃO BRASILEIRA DE NORMAS TÉCNICAS. Bloco vazado modular de concreto - NBR5713. Rio de Janeiro, 1982.

ASSOCIAÇÃO BRASILEIRA DE NORMAS TÉCNICAS. Coordenação modular da construção - NBR5706. Rio de Janeiro, 1977.

BARROS, M. M. B. Metodologia para implantação de tecnologias construtivas racionalizadas na produção de edifícios. São Paulo, 1996. Tese (doutorado) Escola Politécnica, Universidade de São Paulo.

BRESNEN, M.; MARSHAL, N. Building partnerships: case studies of clientcontractor collaboration in the UK construction industry. Construction Management and Economics, London, v.18, p.819-832, 2000a.

BRESNEN, M.; MARSHAL, N. Motivation, commitment and the use of incentives in partnerships and alliances. Construction Management and Economics, London, v.18, p.587-598, 2000b.

CEOTTO, L. H. Retrocesso, não! Entrevista a Ubiratan Leal. Revista Téchne, São Paulo, n. 69, dez. 2002.

CORSWANT, F.; TUNÄLV, C. Coordinating customers and proactive suppliers - A case study of supplier collaboration in product development. Journal of Engineering and Technology Management, New York, v.19, p.249-261, 2002.

DAINTY, A. R. J.; BRISCOE, G. H.; MILLETT, S. J. Subcontractor perspectives on supply chain alliances. Construction Management and Economics, London, v.19, p. 841-848, 2001.

EPUSP/GLASSER-01. Avaliação de desempenho de alvenarias para vedação vertical com blocos de argamassa leve. Convênio de desenvolvimento tecnológico. Relatório n.1. São Paulo, 2000. 
FABRICIO, M. M.; MELHADO, S. B.; SILVA, F. B. Parcerias e estratégias de produção na construção de edifícios. In: ENCONTRO NACIONAL DE ENGENHARIA DE PRODUÇÃO - ENEGEP. Rio de Janeiro, 1999.

FRANCO, L. S. Emprego de telas metálicas soldadas em alvenarias de vedação. Revista Téchne, São Paulo, n.47, jul. 2000.

FRANCO, L. S.; MEDEIROS, J. S. O emprego de telas metálicas eletrosoldadas como componente de ligação entre alvenaria e estrutura. Relatório COqDCC no 20.098 - Convênio EPUSP/MORLAN. Departamento de Engenharia de Construção Civil da Escola Politécnica da Universidade de São Paulo. São Paulo, 1999.

GLASSER, Soluções em Alvenaria e Pavimentação. Sistema de Vedação Modular - Diretrizes para os Projetos de Alvenaria. São Paulo, 2002a.

GLASSER, Soluções em Alvenaria e Pavimentação. Sistema de Vedação Modular - Procedimentos de Execução. São Paulo, 2002b.

HOLANDA, E. P. T. Novas Tecnologias Construtivas para Produção de Vedações Verticais: Diretrizes para o Treinamento da Mão-de-Obra. São Paulo, 2003. Dissertação (mestrado) - Escola Politécnica, Universidade de São Paulo.

ISATTO, E. L. As relações entre empresas construtoras de edificações e seus fornecedores de materiais. Porto Alegre, 1996. Dissertação (mestrado) - Escola de Engenharia, Universidade Federal do Rio Grande do Sul.

KALE, S.; ARDITI, D. General contractors' relationships with subcontractors: a strategic asset. Construction Management and Economics, v.19, p.541-549, 2001.

KORALTAN, S. B.; DIKBAS, A. An assessment of applicability of partnering in the Turkish construction sector. Construction Management and Economics, London, v.20, p.315-321, 2002.

KWAN, A. Y.; OFORI, G. Chinese culture and successful implementation of partnering in Singapore's construction industry. Jounal of Construction Management and Economics, London, v.19, p.619-632, 2001. 
MAHMOUND-JOUNI, S. B. Innovative supply-based strategies in the construction industry. Construction Management and Economics, London, v.18, p.643-650, 2000.

McCUTCHEON, D. M.; GRANT, R. A.; HARTLEY, J. Determinants of new product designers' satisfaction with suppliers' contributions. Journal of Engineering and Technology Management, New York, v.14, p.273-290, 1997.

MINISTÉRIO DO TRABALHO. Norma Regulamentadora NR-18 Condições e meio ambiente do trabalho na indústria da construção. Brasília, 1995.

MITIDIERI FILHO, C. V. et al. Sistema de avaliação técnica de novos produtos e sistemas para a construção de habitações: uma proposta para o Brasil. Téchne, São Paulo, n. 69, dez. 2002.

NAM, C. H.; TATUM, C. B. Leaders and champions for construction innovation. Construction Management and Economics, London, v.15, p.259-270, 1997.

NAM, C. H.; TATUM, C. B. Strategies for technology push: lessons from construction innovations. Journal of Construction Engineering and Management, New York, v.118, n.3, p507-523, 1992.

REZENDE, M. A. P.; ABIKO, A. K. Inovação tecnológica na construção de edificações: novas respostas para antigas questões. In: SIMPÓSIO BRASILEIRO DE GESTÃO DA QUALIDADE E ORGANIZAÇÃO DO TRABALHO NO AMBIENTE CONSTRUÍDO. Fortaleza, 2001.

ROCHA, S. O ajuste do mercado. Revista Téchne, São Paulo, n.30, set./out. 1997.

ROSENFELD, Y. Innovative construction methods. Construction Management and Economics, London, v.12, p.521-541, 1994.

SABBATINI, F. H. Material para o milênio. Revista Construção São Paulo, São Paulo. n.2711, jan. 2000b.

SABBATINI, F. H. Notas de aulas da disciplina 'TG-004 - Tecnologia de produção de vedações verticais' do curso de pós-graduação Lato Sensu do PECE Programa de Educação Continuada da Escola Politécnica da Universidade de São Paulo. São Paulo, 2000a. 
SABBATINI, F. H. As fissuras com origem na interação vedação estrutura. In: SEMINÁRIO DE TECNOLOGIA E GESTÃO NA PRODUÇÃO DE EDIFÍCIOS VEDAÇÕES VERTICAIS. Escola Politécnica da Universidade de São Paulo. São Paulo, 1998a.

SABBATINI, F. H. A industrialização e o processo de produção de vedações: utopia ou elemento de competitividade empresarial? In: SEMINÁRIO DE TECNOLOGIA E GESTÃO NA PRODUÇÃO DE EDIFÍCIOS - VEDAÇÕES VERTICAIS. Escola Politécnica da Universidade de São Paulo. São Paulo, 1998b.

SABBATINI, F. H. Desenvolvimento de métodos, processos e sistemas construtivos. São Paulo, 1989. Tese (doutorado) - Escola Politécnica, Universidade de São Paulo.

SABBATINI, F. H. et. al. Recomendações para a construção de paredes de vedação em alvenaria. Relatório técnico do convênio EPUSP/ENCOL - EP/EN-1. Escola Politécnica da Universidade de São Paulo. São Paulo, 1988.

SABBATINI, F. H. Argamassas. Notas de aula da disciplina 'Materiais de construção civil 1'. Escola Politécnica da Universidade de São Paulo. São Paulo, 1979.

SLAUGHTER, S. E. Models of construction innovation. Journal of Construction Engineering and Management, New York, v.124, n.3, p.226-231, 1998.

TCPO 2000. Tabelas de Composição de Preços para Orçamentos. Primeira edição. Editora Pini Ltda. São Paulo, 1999.

VARGAS, N. Organização do trabalho e capital: estudo da construção habitacional. Rio de Janeiro, 1979. Dissertação (mestrado). Universidade Federal do Rio de Janeiro.

WINCH, G. Zephyrs of creative destruction: understanding the management of innovation in construction. Building Research \& Information, London, v.26, n.4, p.268-279, 1998. 


\section{LISTA DE BIBLIOGRAFIA CONSULTADA}

CARDOSO, F. F. Desenvolvimento de novas formas de gestão da produção. In: SEMINÁRIO INTERNACIONAL DE GESTÃO E TECNOLOGIA NA PRODUÇÃO DE EDIFÍCIOS. São Paulo, 1997.

CARRILLO, P. Technology transfer on joint venture projects in developing countries. Construction Management and Economics, London, v.14, p.45-54, 1996.

CARRILLO, P. Technology transfer: A survey of international construction companies. Construction Management and Economics, London, v.12, p.45-51, 1994.

COSTA, M. R. M. M.; FRANCO, L. S. Método construtivo de alvenaria de vedação de blocos de concreto celular autoclavado. Boletim técnico da Escola Politécnica da Universidade de São Paulo. Departamento de Engenharia de Construção Civil. São Paulo, 1996.

DIAS, S. R. B. M.; HELENE, P. R. L. O fator humano - a motivação do trabalhador a construção civil. Boletim técnico da Escola Politécnica da Universidade de São Paulo. Departamento de Engenharia de Construção Civil. São Paulo, 1992.

GALE, A. W.; FELLOWS, R. F. Challenge and innovation: the challenge to the construction industry. Construction Management and Economics, London, v.8, p431-436, 1990 .

GANN, D. M. Changing technology or managing change? Building Research \& Information, London, v.29, n.3, p.248-249, 2001.

GARZA, J. M.; MITROPOULOS, P. Flavors and mixins of expert systems technology transfer model for AEC industry. Journal of Construction Engineering and Management, New York, v.118, n.3, p.435-453, 1992.

HANDA, V. K. Construction engineers driving into 21 st century. Journal of Construction Engineering and Management, New York, v.122, n.1, p.2-6, 1996. 
HEINECK, L. F. M.; ANDRADE, V. A. A racionalização da execução de alvenarias do tipo convencional e estrutural através de inovações tecnológicas simples. In: 5TH INTERNACIONAL SEMINAR ON STRUCTURAL MANSORY FOR DEVELOPING COUNTRIES. Florianópoli, 1994.

KANGARI, R.; MIYATAKE, Y. Developing and managing innovative construction technologies. Journal of Construction Engineering and Management, New York, v.123, n.1, p72-78, 1997.

LIMA JR., J. R. Qualidade do empreendimento na construção civil - inovação e competitividade. Boletim técnico da Escola Politécnica da Universidade de São Paulo. Departamento de Engenharia de Construção Civil. São Paulo, 1995.

MATTOS, D. M.; AGOPYAN, V. Desenvolvimento de componentes para edificações: blocos cerâmicos de vedação. Boletim técnico da Escola Politécnica da Universidade de São Paulo. Departamento de Engenharia de Construção Civil. São Paulo, 1992.

MELHADO, S. B.; AGOPYAN, V. O conceito de projeto na construção de edifícios: diretrizes para sua elaboração e controle. Boletim técnico da Escola Politécnica da Universidade de São Paulo. Departamento de Engenharia de Construção Civil. São Paulo, 1995.

NAM, C. H.; TATUM, C. B. Toward understanding of product innovation process in construction. Journal of Construction Engineering and Management, New York, v.115, n.4, p.517-534, 1989.

OFORI, G. Construction industry development: role of technology transfer. Construction Management and Economics, London, v.12, p.379-392, 1994.

OFORI, G. Research on construction industry development at the crossroads. Construction Management and Economics, London, v.11, p.175-185, 1993.

SABBATINI, F. H. A atuação da Escola Politécnica no desenvolvimento e na implantação de novas tecnologias construtivas. In: SEMINÁRIO INTERNACIONAL DE GESTÃO E TECNOLOGIA NA PRODUÇÃO DE EDIFÍCIOS. São Paulo, 1997. 
SLAUGHTER, S. E. Implementation of construction innovations. Building Research \& Information, London, v.28, n.1, p.2-17, 2000.

SOUZA, A. L. R.; BARROS, M. M. B.; MELHADO, S. B. Projeto e inovação tecnológica na cons trução de edifícios: implantação no processo tradicional e em processos inovadores. Boletim técnico da Escola Politécnica da Universidade de São Paulo. Departamento de Engenharia de Construção Civil. São Paulo, 1995.

TATUM, C. B. Organizing to increase innovation in construction firms. Journal of Construction Engineering and Management, New York, v.115, n.4, p.602-617, 1989.

THOMAZ, E.; HELENE, P. Qualidade no projeto e na execução de alvenaria estrutural e de alvenarias de vedação em edifícios. Boletim técnico da Escola Politécnica da Universidade de São Paulo. Departamento de Engenharia de Construção Civil. São Paulo, 2000. 


\section{ANEXO A}

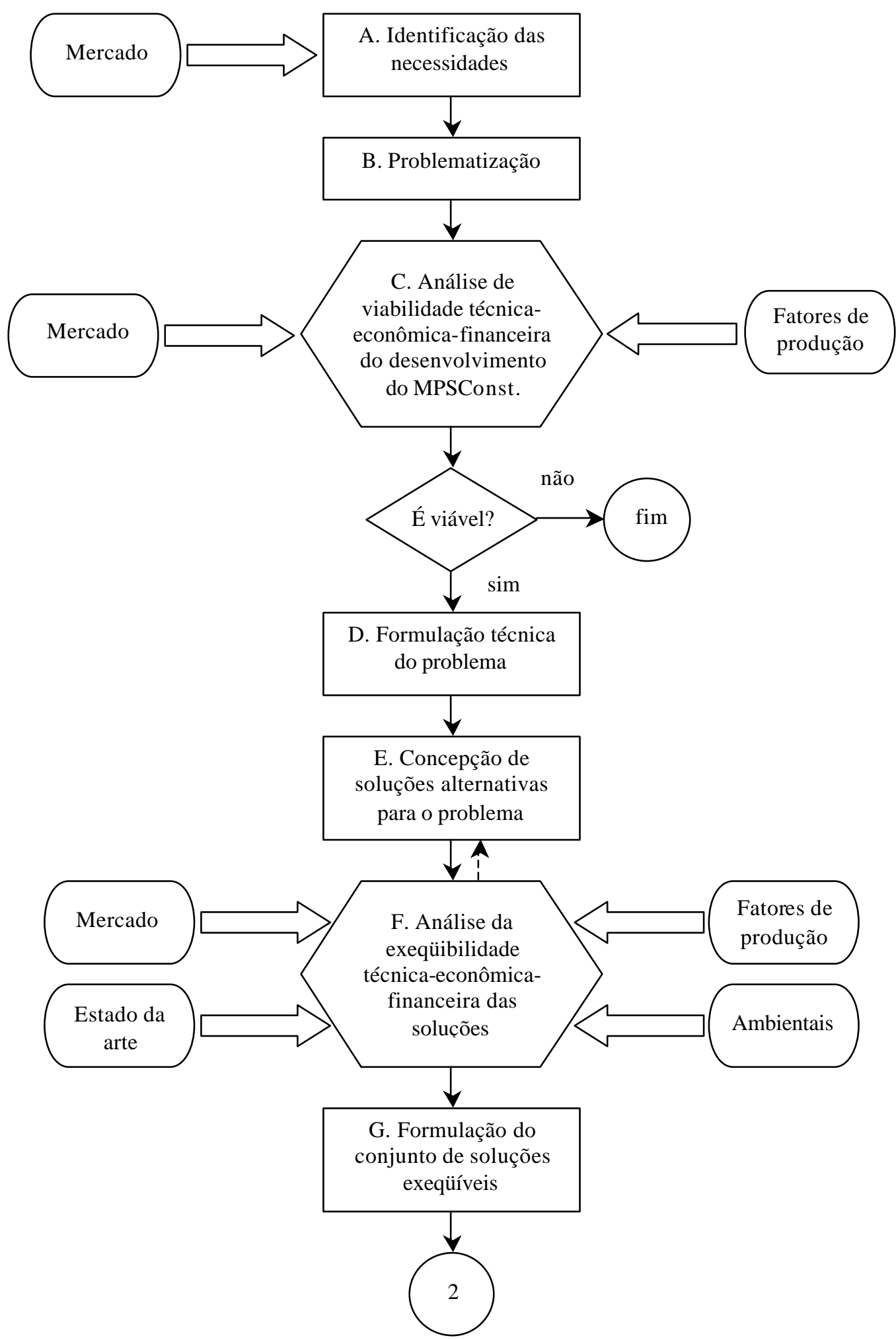

Figura A - Fluxograma da Etapa 1 - Estudos Iniciais (SABBATINI, 1989). 


\begin{abstract}
ANEXO B
Especificações técnicas da argamassa de assentamento e fixação do SVM, conforme catálogo do fornecedor.

Aplicação: recomendado para assentar alvenarias de vedação de blocos de concreto, sílico-calcários e tijolos maciços. É indicado para fixação de alvenarias (encunhamento) devido à sua alta capacidade de aderência e baixo módulo de deformação.
\end{abstract}

Composição: areia de quartzo e à base de rocha calcária com granulometria controlada, cimento Portland e aditivos químicos especiais. Não contém cal.

Classificação/ ABNT: II - alta - b

Densidade aparente: 1,45 a $1,55 \mathrm{~kg} / 1$

Densidade fresca: 1,80 a $1,90 \mathrm{~kg} / 1$

Resistência à compressão aos 28 dias (NBR13279 - cura submersa): 4,0 a 5,0MPa

Módulo de deformação (NBR8522 - plano de carga II/ tangente a 50\%): 1,30 a $1,40 \mathrm{GPa}$

Capacidade de retenção de água (NBR 13277): 93 a 96\%

Teor de ar incorporado (NBR 13278): 16 a 19\%

Ensaio de prisma (resistência de aderência à tração na flexão 14 dias/ Glasser): 2,5 a $3,5 \mathrm{daN} / \mathrm{cm}^{2}$

Adição de água :

- mistura manual: aproximadamente 7,5 litros/saco

- mistura mecânica por batelada: aproximadamente 7,0 litros/saco

Rendimento: consumo real pode variar em função da aplicação. 


\section{ANEXO C}

O SVM possui seis tipos de telas para a utilização nas três espessuras de paredes. As especificações estão descritas na Tabela $\mathrm{C}$ a seguir.

Tabela C - Especificações das telas metálicas empregadas no SVM (GLASSER, 2002a).

\begin{tabular}{|c|c|c|c|}
\hline Tipo & Comprimento $(\mathrm{cm})$ & $\begin{array}{c}\text { Dobra Mínima } \\
(\mathrm{cm})\end{array}$ & Largura $(\mathrm{cm})$ \\
\hline $50 \times 7,5$ & 45 & 5 & 7,5 \\
\hline $50 \times 12$ & 45 & 5 & 12,0 \\
\hline $25 \times 7,5$ & 20 & 5 & 7,5 \\
\hline $25 \times 12$ & 20 & 5 & 12,0 \\
\hline $15 \times 7,5$ & 10 & $5^{*}$ & 7,5 \\
\hline $15 \times 12$ & 10 & $5^{*}$ & 12,0 \\
\hline
\end{tabular}

(*) para casos em que o comprimento da parede for inferior a $10 \mathrm{~cm}$ (espaletas de portas ou janelas) deve-se especificar uma dobra maior que $5 \mathrm{~cm}$.

Para paredes com espessura nominal igual a $10 \mathrm{~cm}$ deve-se especificar uma tela de $7,5 \mathrm{~cm}$. Para paredes com espessura nominal igual a $15 \mathrm{~cm}$ deve-se especificar uma tela de $12,0 \mathrm{~cm}$. Para paredes com espessura nominal igual a $20 \mathrm{~cm}$ deve-se especificar duas telas de $7,5 \mathrm{~cm}$ (posicionadas sobre os septos longitudinais dos blocos e distantes entre si por aproximadamente $4 \mathrm{~cm}$ ).

Deve-se especificar sempre a tela inteira $(50 \mathrm{~cm})$ e os demais modelos são utilizados quando existir limitações físicas, por exemplo, eletrodutos verticais que passam a uma distância inferior a $45 \mathrm{~cm}$ do pilar; janelas posicionadas a uma distância inferior a $45 \mathrm{~cm}$ do pilar; espaletas de portas; etc. Na ligação alvenaria/estrutura a tela deve ultrapassar o limite da segunda junta vertical.

Para os casos de ligação alvenaria/estrutura ou parede/parede a tela deve ser aplicada de modo a ficar centralizada em relação à espessura da junta horizontal, a cada duas fiadas a partir da terceira junta horizontal/face superior da segunda fiada. 


\section{ANEXO D}

Dimensões e especificações dos elementos pré-fabricados utilizados pelo SVM.

a) vergas: as vergas têm as dimensões (em $\mathrm{mm}$ ) e massas (em $\mathrm{kg}$ ) apresentadas na Tabela D.1 a seguir.

Tabela D.1 - Dimensões e massa das vergas utilizadas no SVM (GLASSER, 2002a).

\begin{tabular}{|c|c|c|}
\hline Nomenclatura & $\begin{array}{c}\text { Dimensões }(\mathrm{mm}) \\
\text { Compr } \times \text { larg } \times \text { alt }\end{array}$ & Massa (kg) \\
\hline VP7010 & $700 \times 90 \times 190$ & 15 \\
\hline VP7015 & $700 \times 140 \times 190$ & 11 \\
\hline VP8010 & $800 \times 90 \times 190$ & 16 \\
\hline VP8015 & $800 \times 140 \times 190$ & 18 \\
\hline VP9010 & $900 \times 90 \times 190$ & 12 \\
\hline VP9015 & $900 \times 140 \times 190$ & 16 \\
\hline
\end{tabular}

Obs.: para paredes com espessura nominal igual a $20 \mathrm{~cm}$ são utilizadas duas peças com largura de $90 \mathrm{~mm}$ justapostas.

$\mathrm{O}$ vazado interno das abas laterais das vergas $\mathrm{U}$ tem duas finalidades:

- permitir a passagem de eletrodutos, já que o interruptor da luz encontra-se sempre próximo às aberturas;

- permitir o ajuste, em obra, do elemento pré-fabricado à dimensão da espaleta da porta. Alguns projetistas costumam especificar $7,5 \mathrm{~cm}$ ou até mesmo $5,0 \mathrm{~cm}$ para este detalhe. O corte das abas é facilmente efetuado com uma máquina de corte com disco diamantado.

O SVM também possui vergas retas pré-fabricadas que são utilizadas nos seguintes casos:

- existência de contrapiso superior a $3 \mathrm{~cm}$; 
- existência de vãos com aberturas diferentes do padronizado no item anterior (como no caso de portas de elevadores, vergas para aberturas diversas como quadros elétricos);

As dimensões (em mm) e massas (em kg) dessas peças são apresentadas na Tabela D.2 a seguir.

Tabela D.2 - Dimensões e massa das vergas retas utilizadas no SVM (GLASSER, 2002a).

\begin{tabular}{|c|c|c|}
\hline Nomenclatura & $\begin{array}{l}\text { Dimensões }(\mathrm{mm}) \\
\text { Compr x larg x alt }\end{array}$ & Massa $(\mathrm{kg})$ \\
\hline VR9010 & $900 \times 90 \times 90$ & 16 \\
\hline VR10010 & $1000 \times 90 \times 90$ & 18 \\
\hline VR10015 & $1000 \times 140 \times 90$ & 18 \\
\hline VR11010 & $1100 \times 90 \times 90$ & 18 \\
\hline VR11015 & $1100 \times 140 \times 90$ & 20 \\
\hline VR12010 & $1200 \times 90 \times 90$ & 22 \\
\hline VR12015 & $1200 \times 140 \times 90$ & 22 \\
\hline VR12020 & $1200 \times 190 \times 90$ & 26 \\
\hline VR15010 & $1500 \times 90 \times 90$ & 27 \\
\hline VR15015 & $1500 \times 140 \times 90$ & 27 \\
\hline VR15020 & $1500 \times 190 \times 90$ & 32 \\
\hline
\end{tabular}

Obs.: as peças VR9010, VR10010, VR11010, 12010 e VR15010 são maciças. Para paredes com espessura nominal de $20 \mathrm{~cm}$ são utilizadas duas peças de largura de $90 \mathrm{~mm}$ justapostas, sendo que somente para os comprimentos de $1200 \mathrm{~mm}$ e $1500 \mathrm{~mm}$ estão disponíveis peças com largura de 190mm. 
b) contra-vergas: as contra-vergas têm dimensões (em $\mathrm{mm}$ ) e massas (em $\mathrm{kg}$ ) apresentadas na Tabela D.3 a seguir:

Tabela D.3 - Dimensões e massa das contra-vergas utilizadas no SVM (GLASSER, 2002a).

\begin{tabular}{|c|c|c|}
\hline Nomenclatura & $\begin{array}{c}\text { Dimensões (mm) } \\
\text { Compr x larg x alt }\end{array}$ & Massa (kg) \\
\hline CV6010 & $600 \times 90 \times 90$ & 11 \\
\hline CV6015 & $600 \times 140 \times 90$ & 13 \\
\hline CV6020 & $600 \times 190 \times 90$ & 16 \\
\hline CV9015 & $900 \times 140 \times 90$ & 19 \\
\hline CV9020 & $900 \times 190 \times 90$ & 16 \\
\hline
\end{tabular}

Obs.: a peça CV6010 é maciça. 
ANEXO E

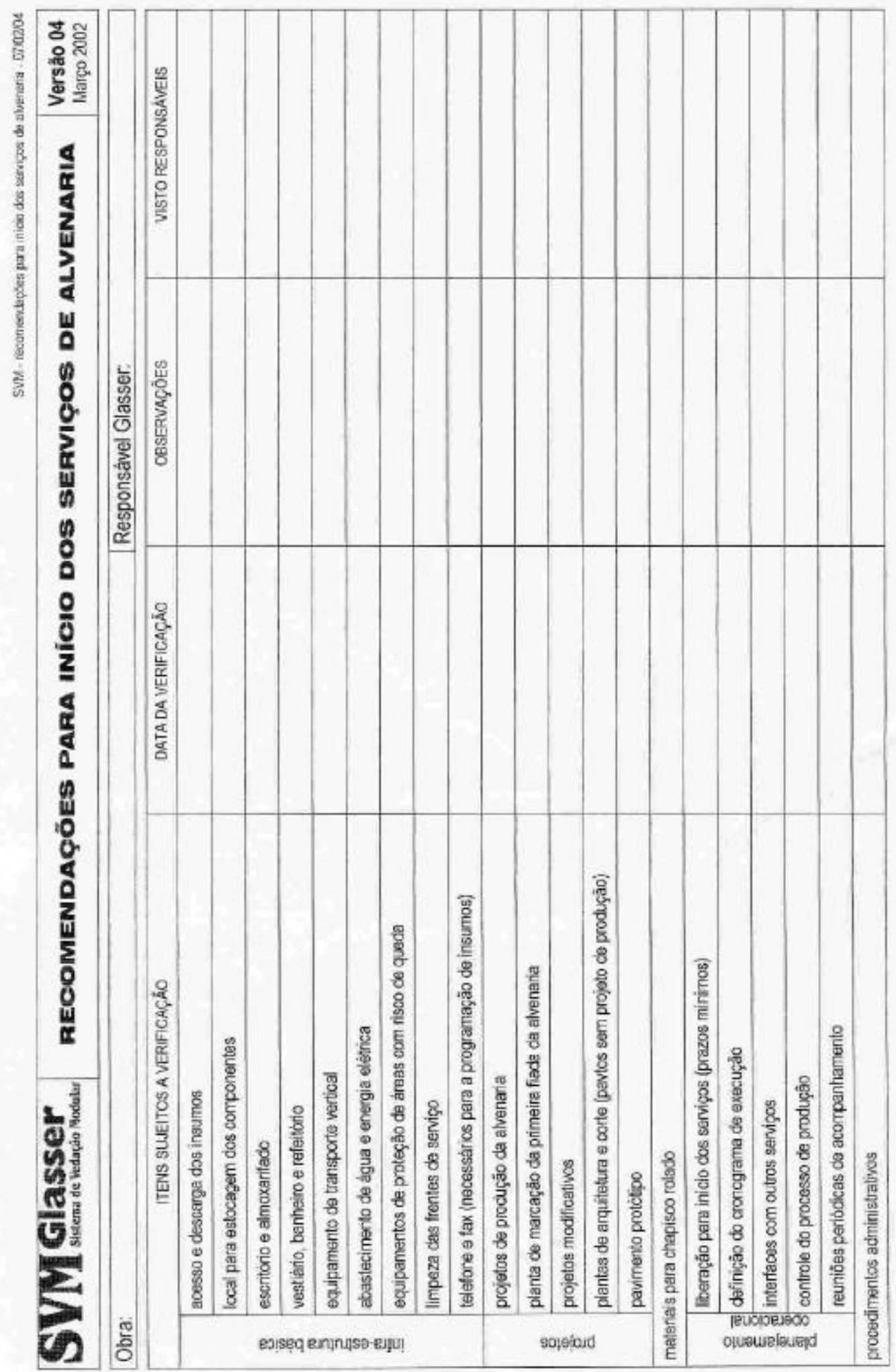


ANEXO F

SUM - Froggraca ve - 06000

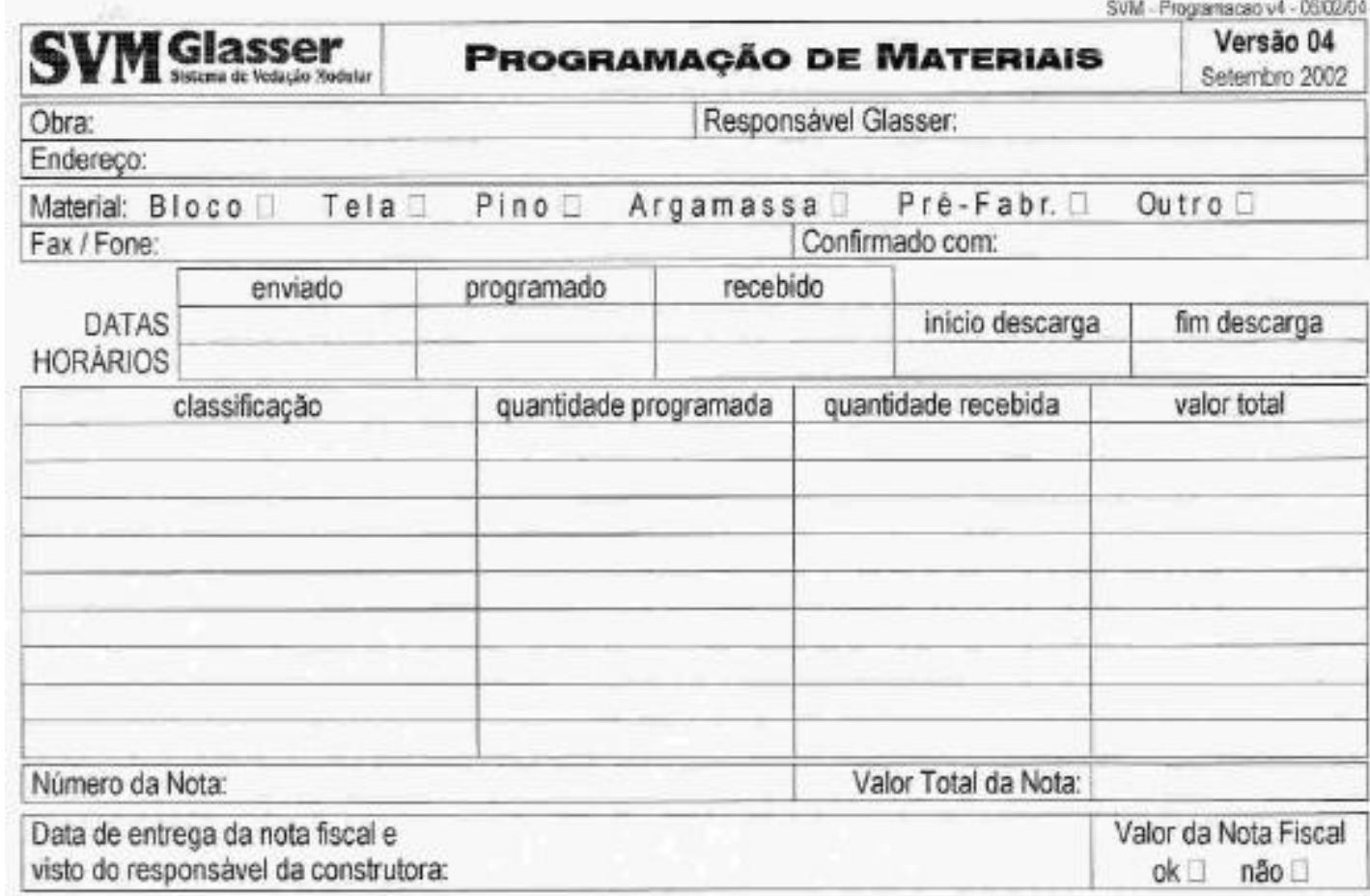


ANEXO G

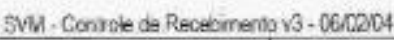

\section{S. VI Glasser \\ Conthole de Recebimento \\ Versão 03}

Obra:

Responsavel Glasser

\begin{tabular}{|c|c|c|c|c|}
\hline Data & Material & Quantidade & Valor & Observaçīes \\
\hline & & & & \\
\hline & & & & \\
\hline & & & & \\
\hline & & & & \\
\hline & & & & \\
\hline & & & & \\
\hline & & & & \\
\hline & & & & \\
\hline & & & & \\
\hline & & & & \\
\hline & & & & \\
\hline & & & & \\
\hline & & & & \\
\hline & & & & \\
\hline & & & & \\
\hline & & & & \\
\hline & & & & \\
\hline & & & & 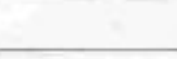 \\
\hline & & & & \\
\hline & & & & \\
\hline & & & & \\
\hline & & & & \\
\hline & & & & \\
\hline & & & & \\
\hline & & & & \\
\hline & & & & \\
\hline & & & & \\
\hline & & & & \\
\hline & & & & \\
\hline & & & & \\
\hline & & & & \\
\hline & & & & \\
\hline
\end{tabular}


ANEXO H

SVM - Lerantamento de areas $2 \sqrt{2}, 060204$ SVMGiasser

Levantamento de Áreas

Versăo 02

Obra:

Pavimento:

Folha: de

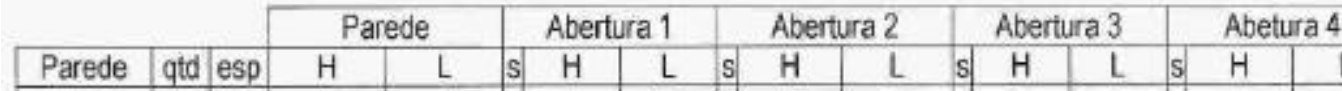

\begin{tabular}{|c|c|c|c|c|c|c|c|c|c|c|c|c|}
\hline Parede & gtd $e$ & esp & $\mathrm{H}$ & $\mathrm{L}$ & $\begin{array}{lll} \\
\end{array}$ & L & s $\quad H$ & L & s) $\mathrm{H}$ & $\mathrm{L}$ & s $\quad H$ & $\mathrm{~L}$ \\
\hline & & & & & & & & & & & & \\
\hline & & & & & & & & & & & & \\
\hline & & & & & & & & & & & & \\
\hline & & & & & & & & & & & & \\
\hline & & & & & & & & & & & & \\
\hline & & & & & & & & & & & & \\
\hline & & & & & & & & & & & & \\
\hline & & & & & & & & & & & & \\
\hline & & & & & & & & & & & & \\
\hline & & & & & & & & & & & & \\
\hline & & & & & & & & & & & & \\
\hline & & & & & & & & & & & & \\
\hline & & & & & & & & & - & & H & \\
\hline & & & & & & & & & - & & 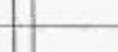 & \\
\hline & & & & & & & & & 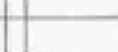 & & & \\
\hline & & & & & & & & & & & & \\
\hline & & & & & & & & & & & & \\
\hline & & & & & & & & & & & & \\
\hline & & & & & & & & & & & & \\
\hline & & & & & & & & & & & & \\
\hline & & & & & & & & & & & & \\
\hline & & & & & & & & & & & & \\
\hline & & & & & & & & & & & & \\
\hline & & & & & & & & & & & & \\
\hline & & & & & & & & & & & & \\
\hline & & & & & & & & & & & & \\
\hline & & & & & & & & & 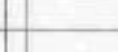 & & & \\
\hline & & & & & & & & & 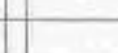 & & & \\
\hline & & & & & & & & & & & 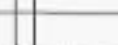 & \\
\hline & & & & & & & & & & & & \\
\hline & & & & & & & & & & & & \\
\hline & & & & & & & & & & & & \\
\hline & & & & & & & & & & & & \\
\hline & & & & & & & & & & & & \\
\hline & & & & & & & & & & & & \\
\hline & & & & & & & & & & & 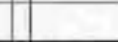 & \\
\hline & & & & & & & & & & & 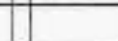 & \\
\hline & & & & & & & & & & & & \\
\hline & & & & & & & & & & & & \\
\hline & & & & & & & & & & & 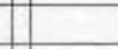 & \\
\hline & & & & & & & & & & & & \\
\hline & & & & & & & & & & & & \\
\hline
\end{tabular}


ANEXO I

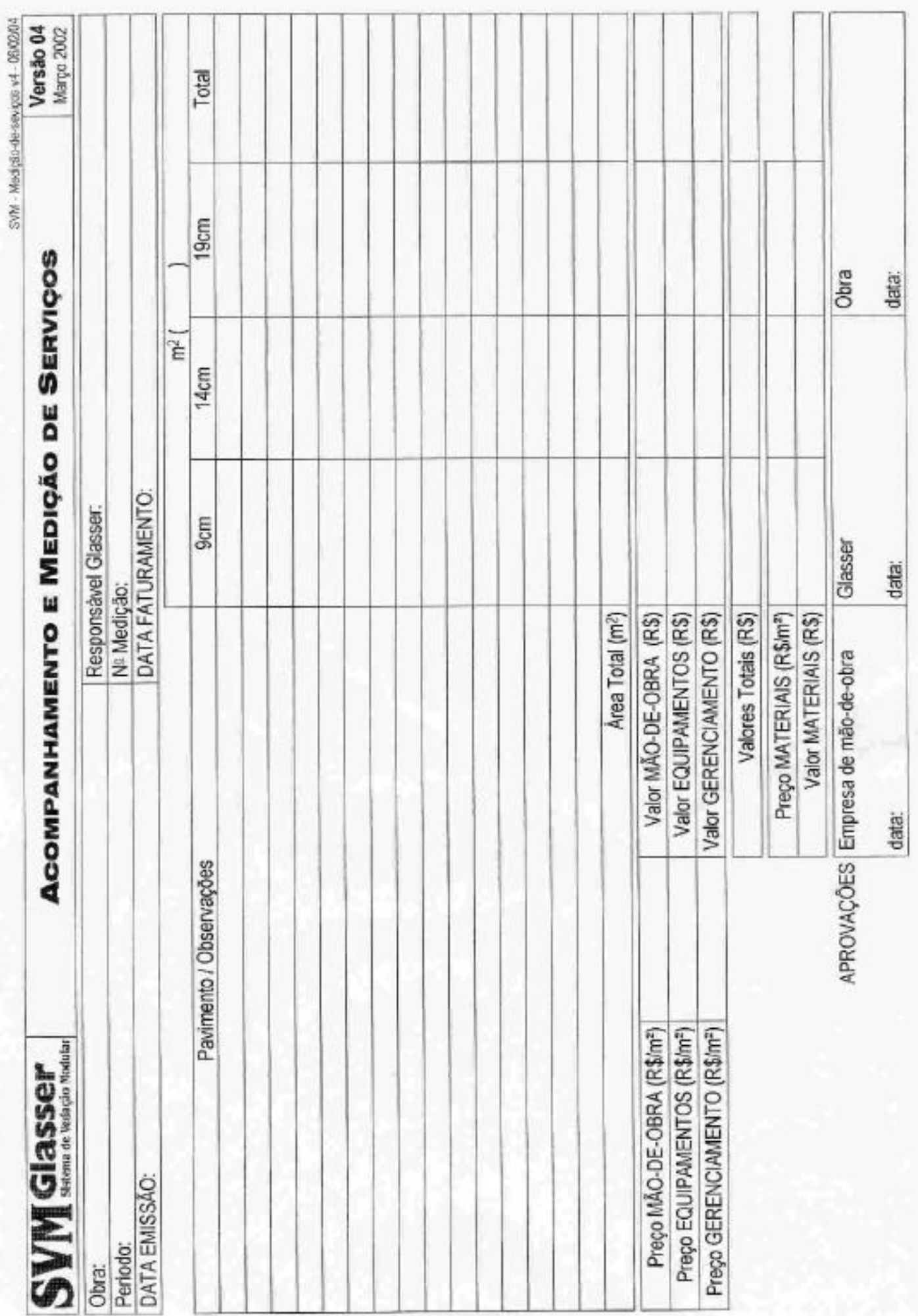




\section{ANEXO J}

A seguir apresentam-se as planilhas utilizadas no SVM nos controles (a) de liberação para início dos serviços, (b) do processo e (c) de aceitação, considerando-se os serviços de marcação, elevação e fixação.

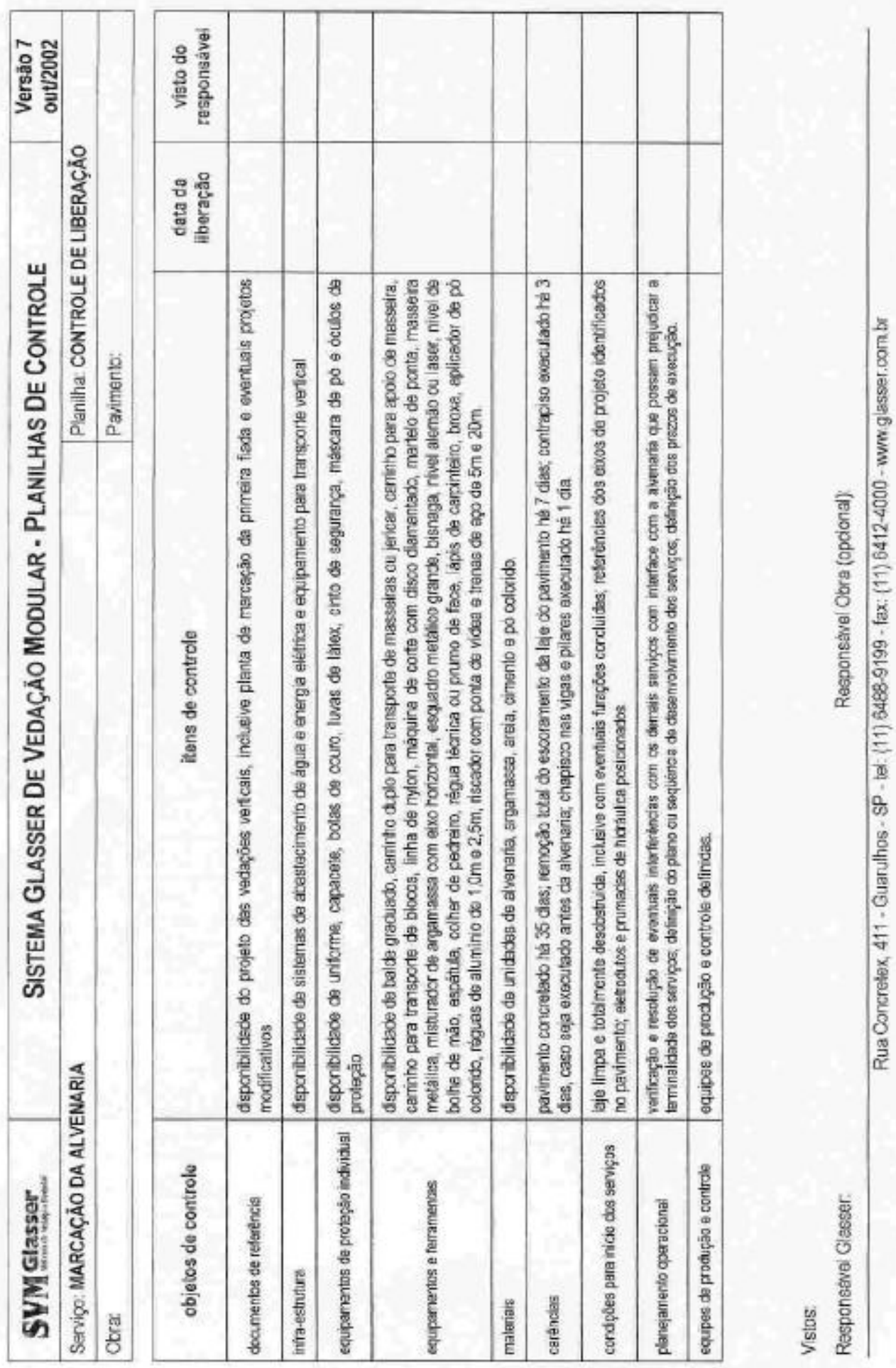




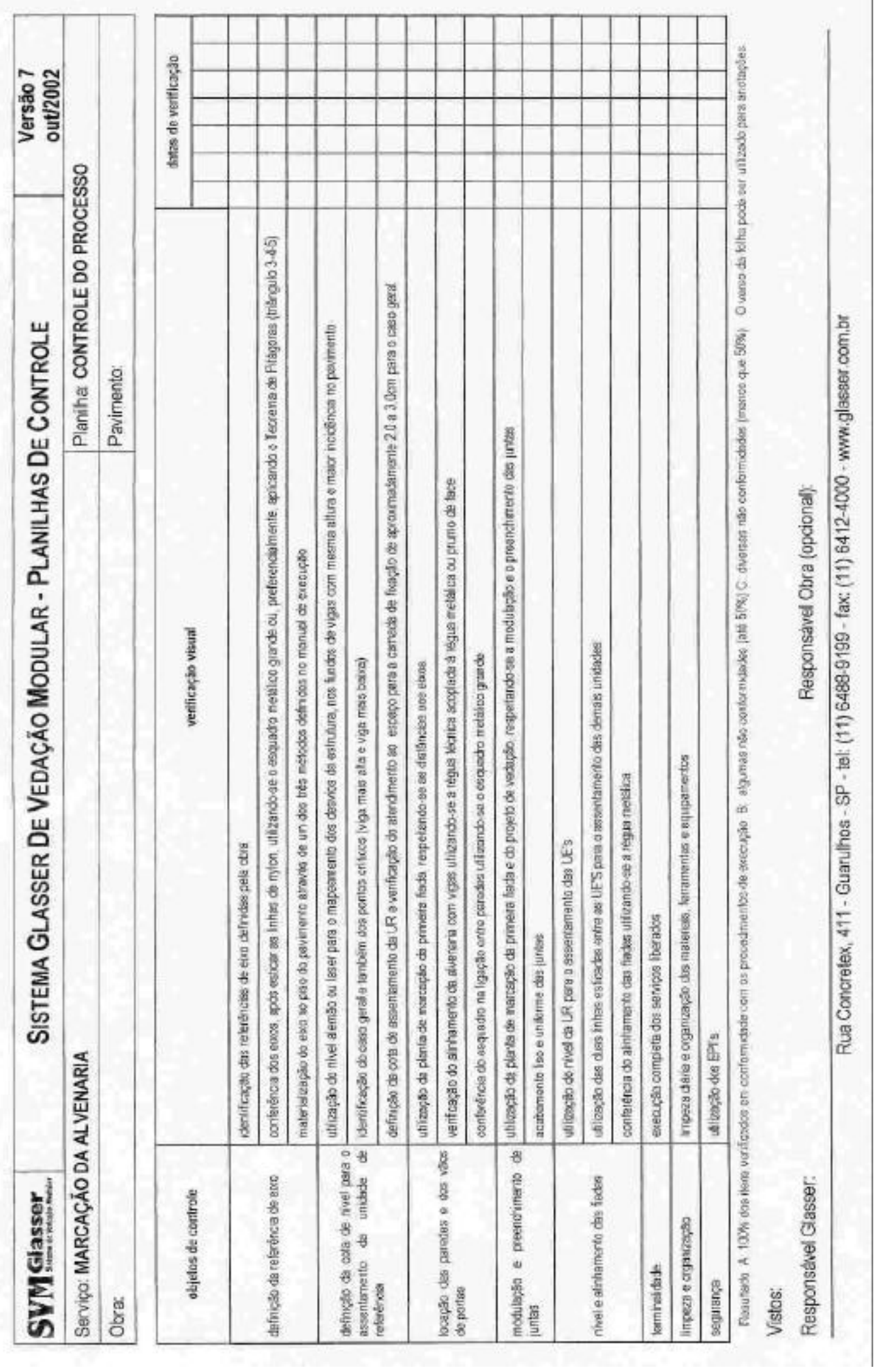




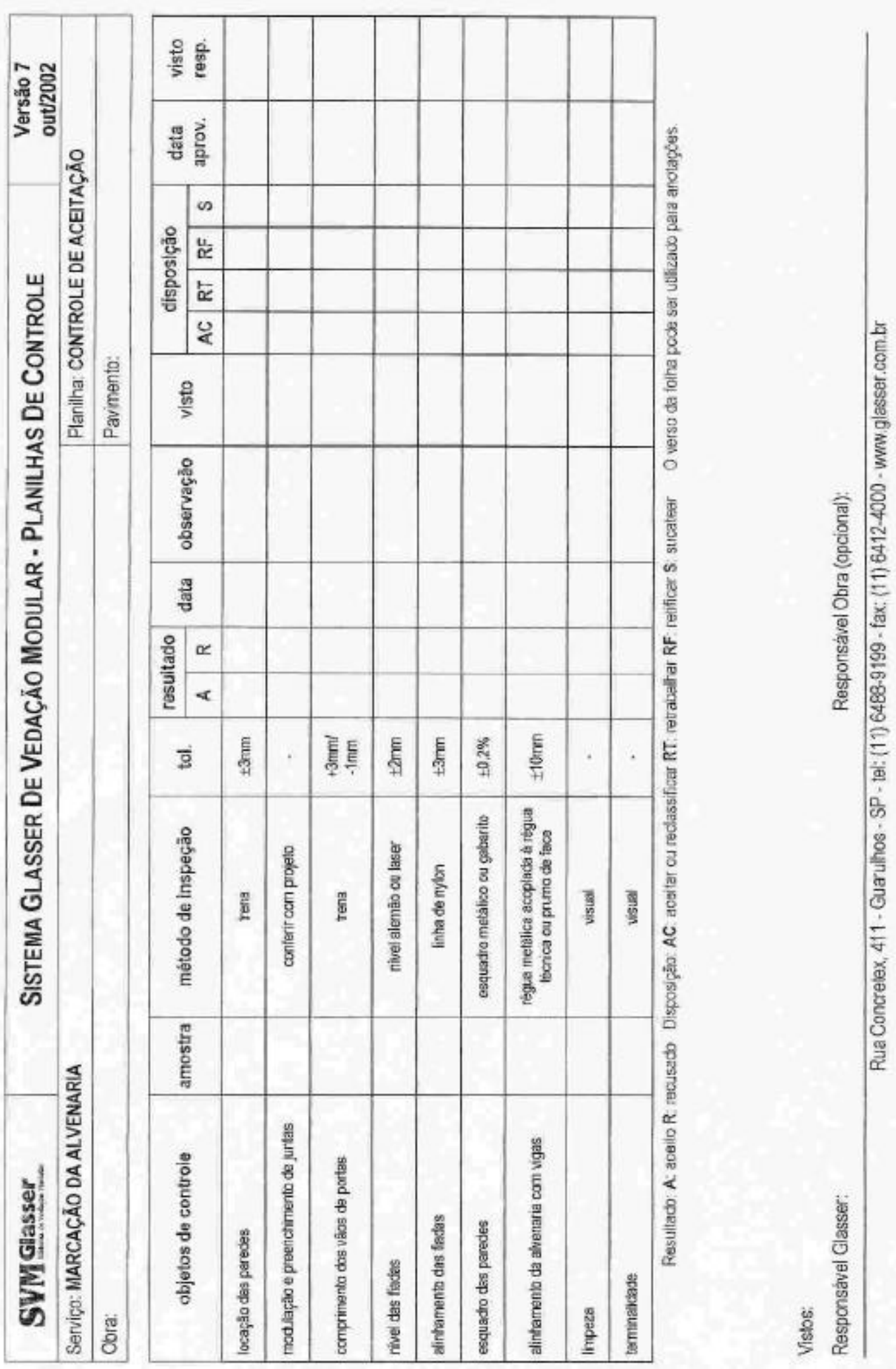




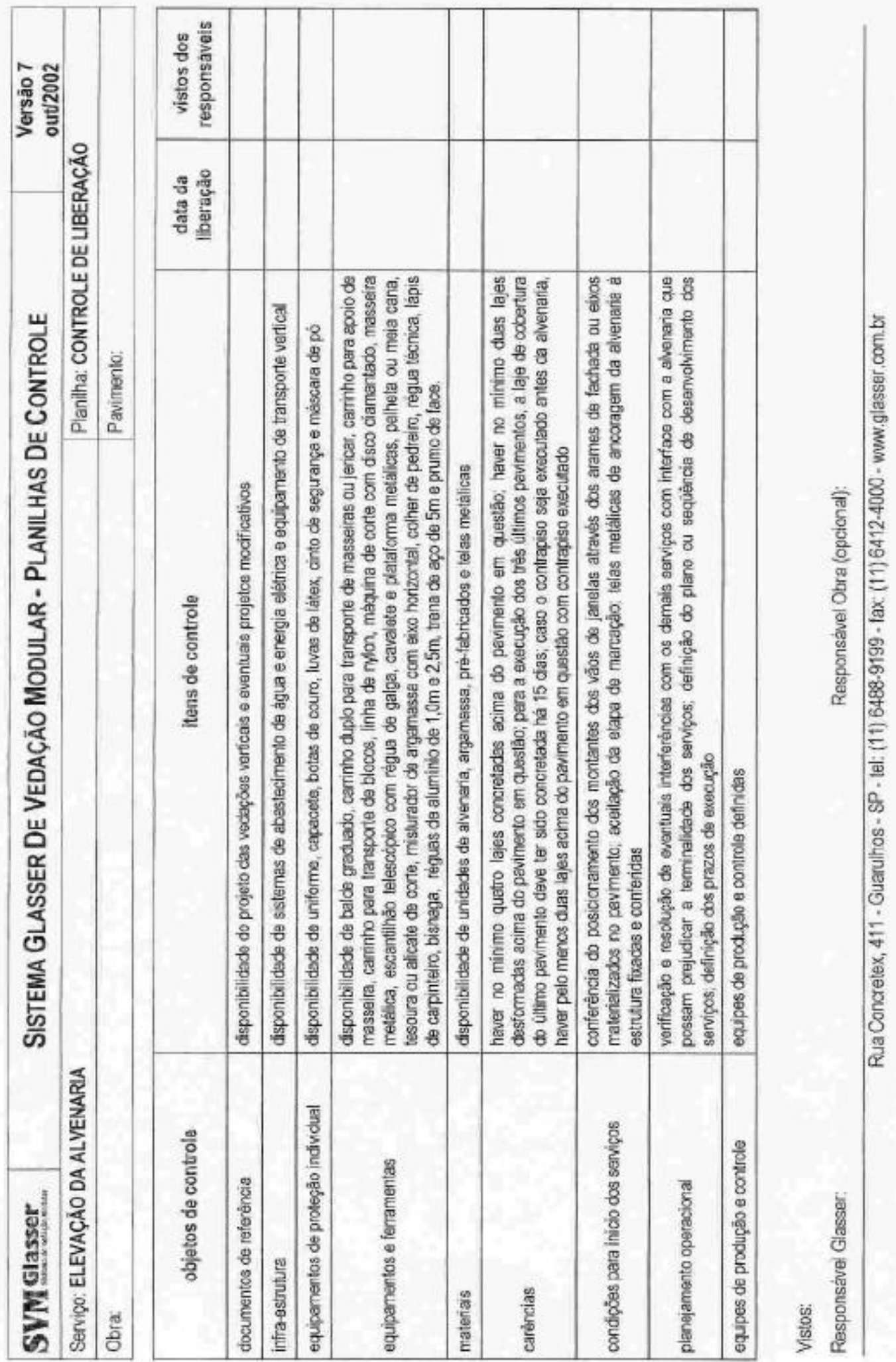




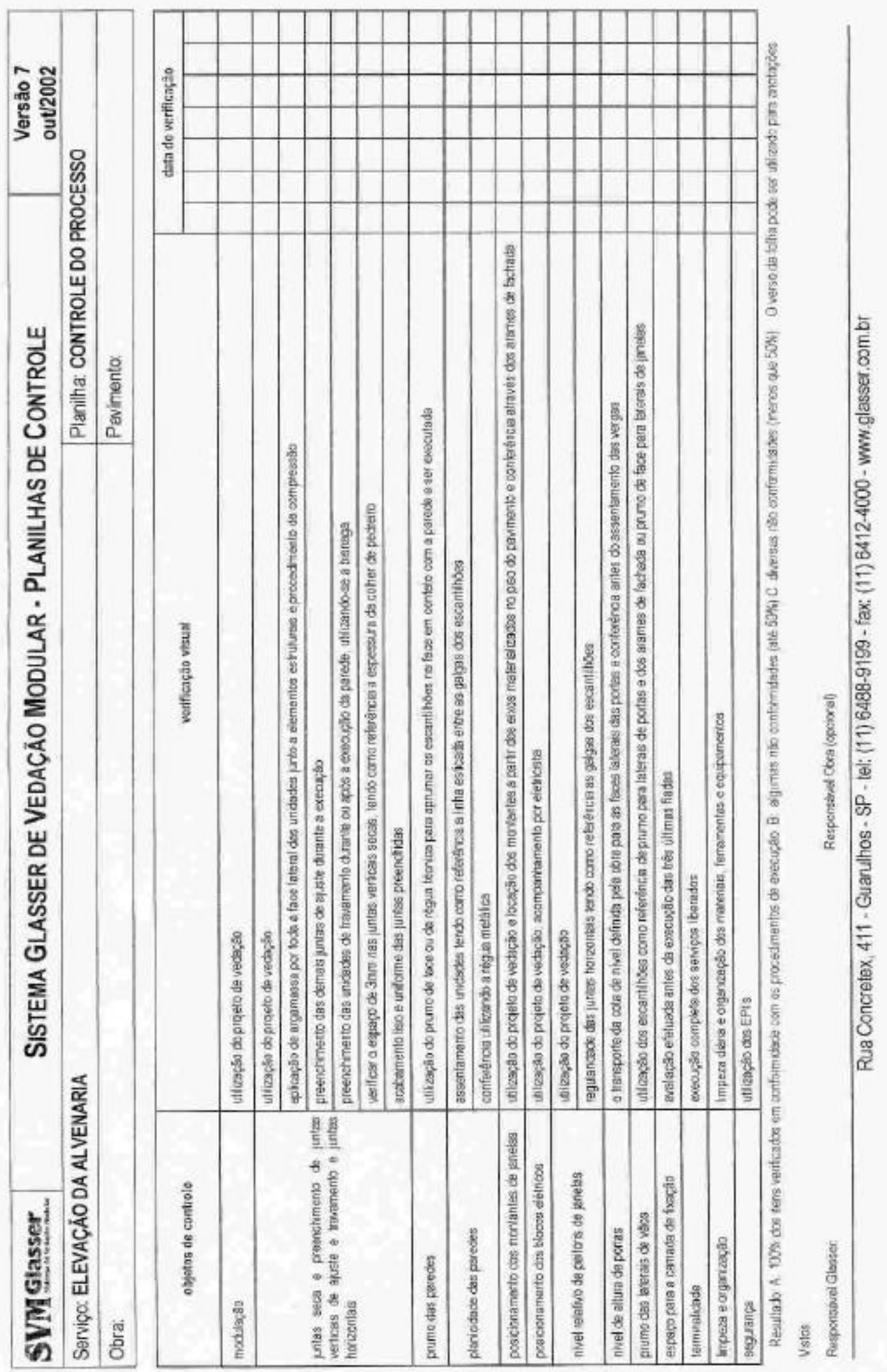




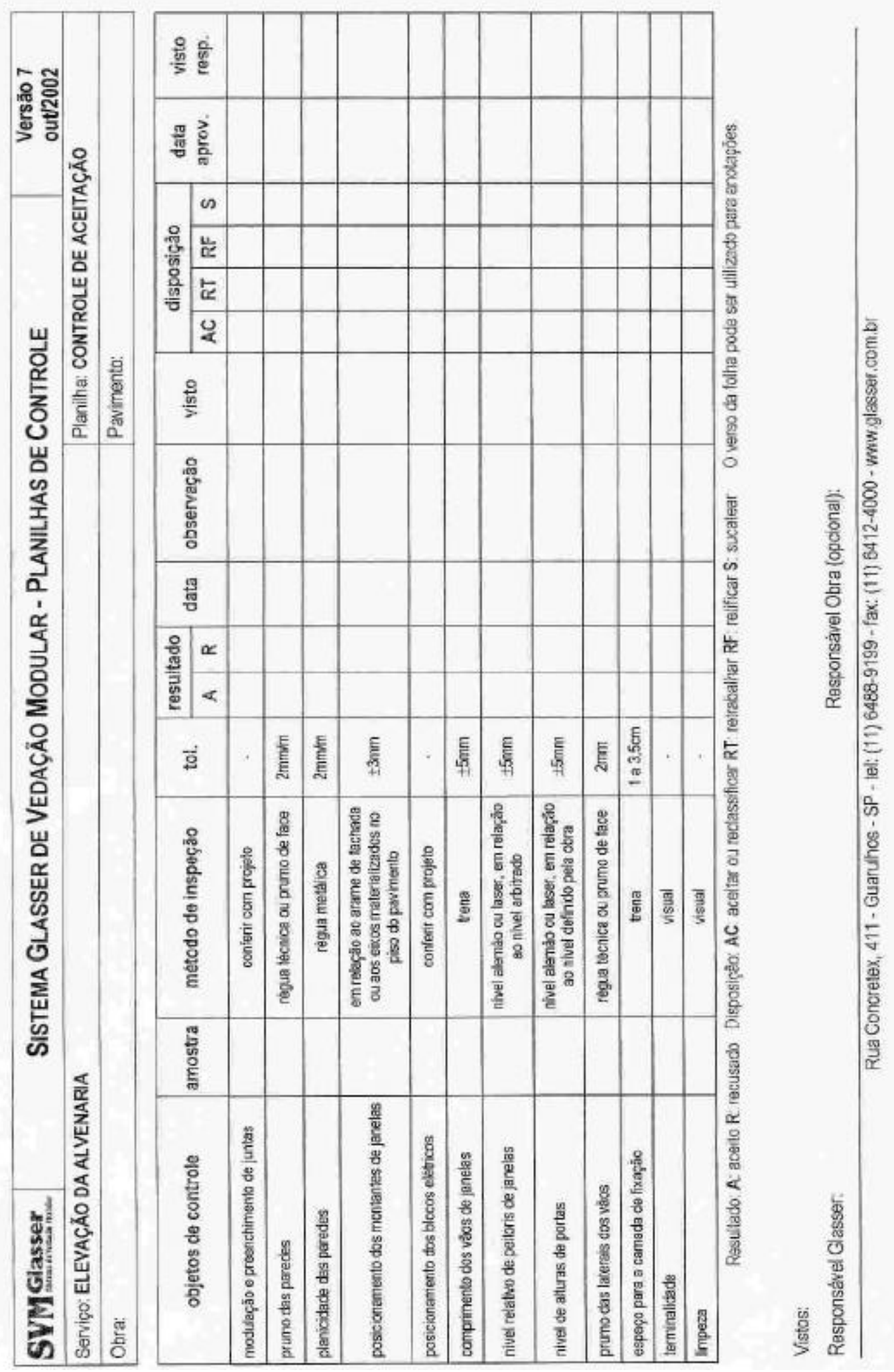




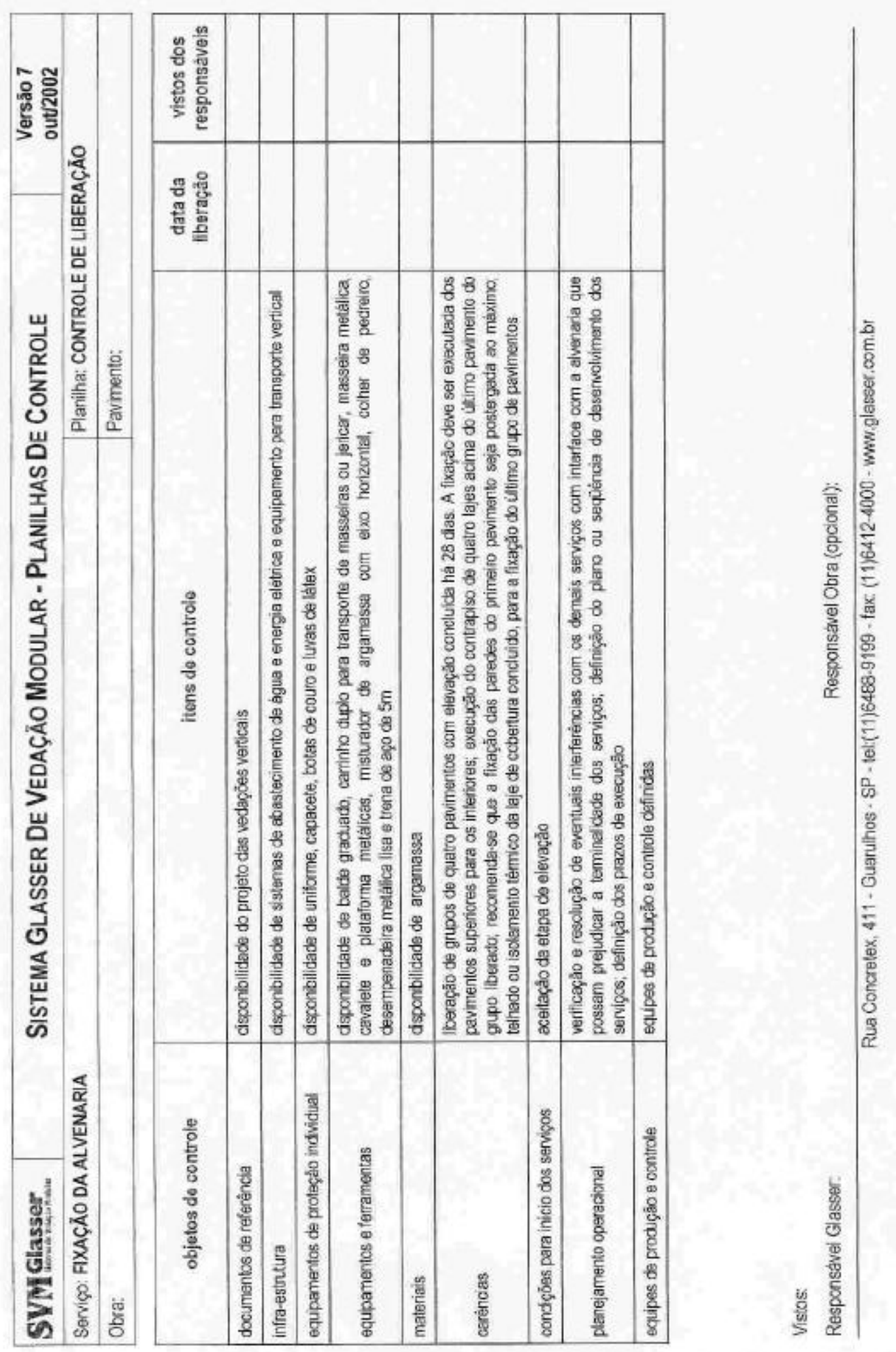



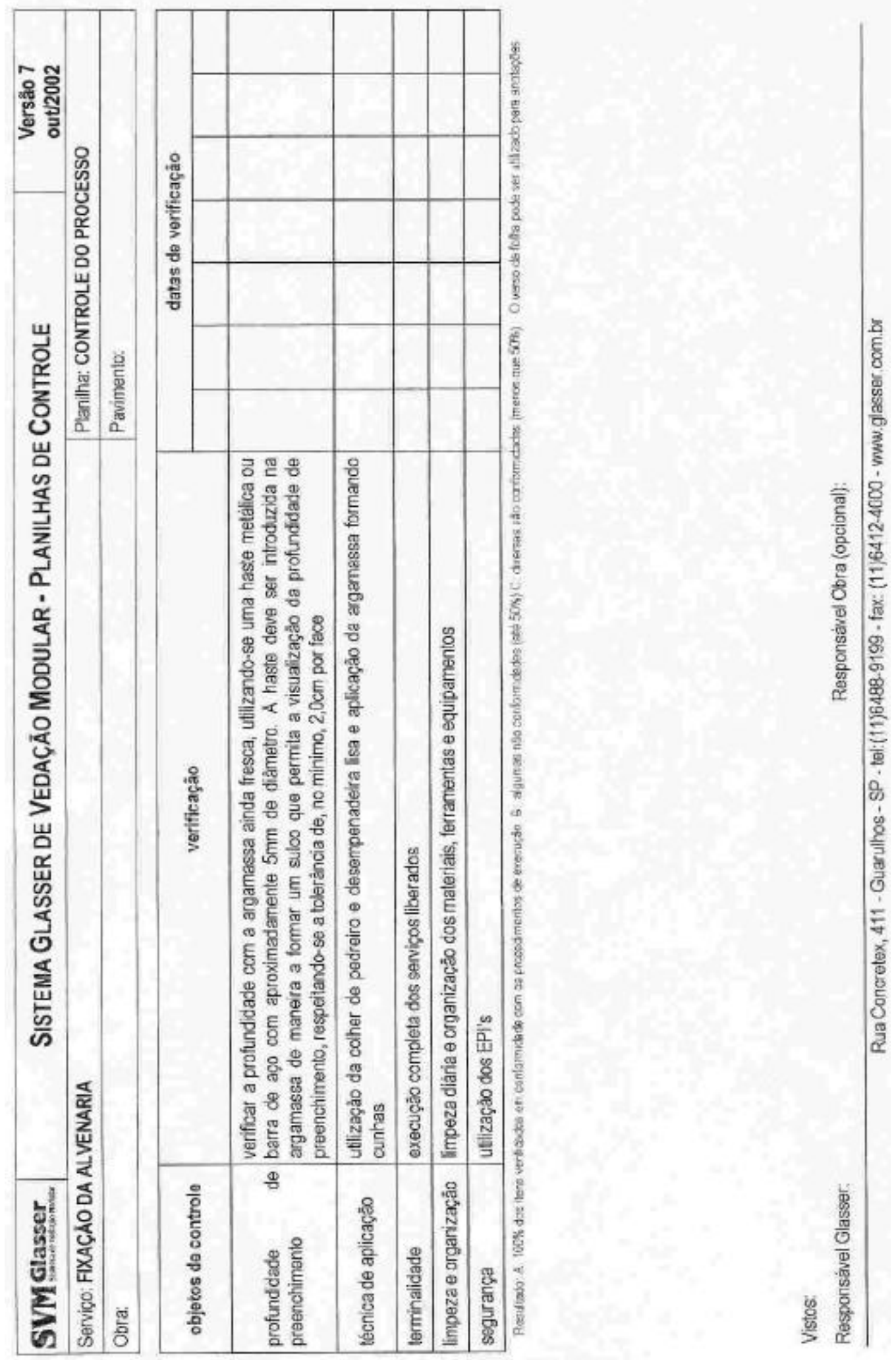

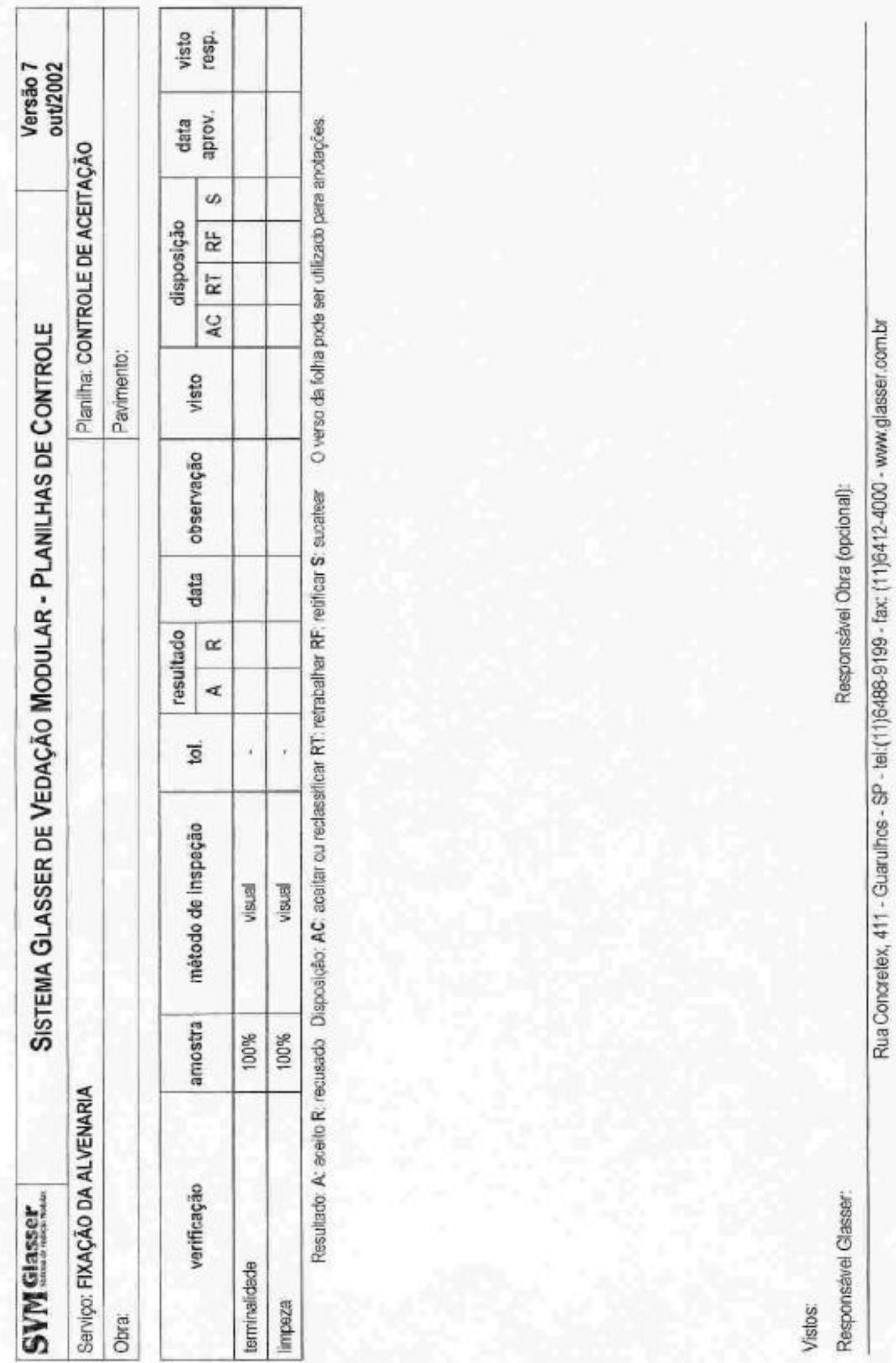
